Cochrane Database of Systematic Reviews

\title{
Clopidogrel plus aspirin versus aspirin alone for preventing cardiovascular events (Review)
}

Squizzato A, Bellesini M, Takeda A, Middeldorp S, Donadini MP

Squizzato A, Bellesini M, Takeda A, Middeldorp S, Donadini MP.

Clopidogrel plus aspirin versus aspirin alone for preventing cardiovascular events.

Cochrane Database of Systematic Reviews 2017, Issue 12. Art. No.: CD005158.

DOI: 10.1002/14651858.CD005158.pub4.

www.cochranelibrary.com 
TABLE OF CONTENTS

HEADER 1

ABSTRACT

PLAIN LANGUAGE SUMMARY

SUMMARY OF FINDINGS

2

BACKGROUND

OBJECTIVES

METHODS

RESULTS

Figure 1.

Figure 2.

Figure 3.

Figure 4.

Figure 5.

Figure 6.

DISCUSSION

AUTHORS' CONCLUSIONS

ACKNOWLEDGEMENTS

REFERENCES

CHARACTERISTICS OF STUDIES

DATA AND ANALYSES

Analysis 1.1. Comparison 1 Clopidogrel (Clo) plus aspirin (ASA) versus aspirin alone, Outcome 1 Cardiovascular mortality. .....

Analysis 1.2. Comparison 1 Clopidogrel (Clo) plus aspirin (ASA) versus aspirin alone, Outcome 2 All-cause mortality.

Analysis 1.3. Comparison 1 Clopidogrel (Clo) plus aspirin (ASA) versus aspirin alone, Outcome 3 Fatal and non-fatal myocardial infarction.

Analysis 1.4. Comparison 1 Clopidogrel (Clo) plus aspirin (ASA) versus aspirin alone, Outcome 4 Fatal and non-fatal ischaemic stroke.

Analysis 1.5. Comparison 1 Clopidogrel (Clo) plus aspirin (ASA) versus aspirin alone, Outcome 5 Major bleeding.

Analysis 1.6. Comparison 1 Clopidogrel (Clo) plus aspirin (ASA) versus aspirin alone, Outcome 6 Minor bleeding.

Analysis 1.7. Comparison 1 Clopidogrel (Clo) plus aspirin (ASA) versus aspirin alone, Outcome 7 Repeated revascularization for CABG.

Analysis 1.8. Comparison 1 Clopidogrel (Clo) plus aspirin (ASA) versus aspirin alone, Outcome 8 Saphenous vein graft patency for CABG.

Analysis 1.9. Comparison 1 Clopidogrel (Clo) plus aspirin (ASA) versus aspirin alone, Outcome 9 Amputation for people with PAD.

Analysis 1.10. Comparison 1 Clopidogrel (Clo) plus aspirin (ASA) versus aspirin alone, Outcome 10 Sensitivity analysis - randomeffects model: cardiovascular mortality.

Analysis 1.11. Comparison 1 Clopidogrel (Clo) plus aspirin (ASA) versus aspirin alone, Outcome 11 Sensitivity analysis - randomeffects model: fatal and non-fatal myocardial infarction.

Analysis 1.12. Comparison 1 Clopidogrel (Clo) plus aspirin (ASA) versus aspirin alone, Outcome 12 Sensitivity analysis - randomeffects model: fatal and non-fatal ischaemic stroke.

Analysis 1.13. Comparison 1 Clopidogrel (Clo) plus aspirin (ASA) versus aspirin alone, Outcome 13 Sensitivity analysis - randomeffects model: major bleeding.

Analysis 1.14. Comparison 1 Clopidogrel (Clo) plus aspirin (ASA) versus aspirin alone, Outcome 14 Sensitivity analysis - randomeffects model: minor bleeding.

Analysis 1.15. Comparison 1 Clopidogrel (Clo) plus aspirin (ASA) versus aspirin alone, Outcome 15 Sensitivity analysis - randomeffects model: repeated revascularization for people with CABG.

Analysis 1.16. Comparison 1 Clopidogrel (Clo) plus aspirin (ASA) versus aspirin alone, Outcome 16 Sensitivity analysis - randomeffects model: SVG patency for people with CABG.

Analysis 1.17. Comparison 1 Clopidogrel (Clo) plus aspirin (ASA) versus aspirin alone, Outcome 17 Sensitivity analysis - randomeffects model: amputation for people with PAD.

Analysis 1.18. Comparison 1 Clopidogrel (Clo) plus aspirin (ASA) versus aspirin alone, Outcome 18 Sensitivity analysis - low risk of bias (RoB): cardiovascular mortality. 
Analysis 1.19. Comparison 1 Clopidogrel (Clo) plus aspirin (ASA) versus aspirin alone, Outcome 19 Sensitivity analysis - low RoB: all-cause mortality.

Analysis 1.20. Comparison 1 Clopidogrel (Clo) plus aspirin (ASA) versus aspirin alone, Outcome 20 Sensitivity analysis - low RoB: fatal and non-fatal myocardial infarction.

Analysis 1.21. Comparison 1 Clopidogrel (Clo) plus aspirin (ASA) versus aspirin alone, Outcome 21 Sensitivity analysis - low RoB: major bleeding.

Analysis 1.22. Comparison 1 Clopidogrel (Clo) plus aspirin (ASA) versus aspirin alone, Outcome 22 Sensitivity analysis - low RoB: minor bleeding.

APPENDICES

WHAT'S NEW

HISTORY

CONTRIBUTIONS OF AUTHORS

DECLARATIONS OF INTEREST

SOURCES OF SUPPORT

DIFFERENCES BETWEEN PROTOCOL AND REVIEW

INDEX TERMS 
[Intervention Review]

\section{Clopidogrel plus aspirin versus aspirin alone for preventing cardiovascular events}

Alessandro Squizzato1, Marta Bellesini², Andrea Takeda33, Saskia Middeldorp4, Marco Paolo Donadini²

1Research Center on Thromboembolic Disorders and Antithrombotic Therapies, Department of Medicine and Surgery, School of Medicine, University of Insubria, Varese, Italy. ${ }^{2}$ Research Center on Thromboembolic Disorders and Antithrombotic Therapies, Department of Clinical and Experimental Medicine, School of Medicine, University of Insubria, Varese, Italy. ${ }^{3}$ Farr Institute of Health Informatics Research, University College London, London, UK. ${ }^{4}$ Department of Vascular Medicine, Academic Medical Center, Amsterdam, Netherlands

Contact address: Alessandro Squizzato, Research Center on Thromboembolic Disorders and Antithrombotic Therapies, Department of Medicine and Surgery, School of Medicine, University of Insubria, c/o Medicina 1, ASST Settelaghi Ospedale di Circolo, viale Borri, 57, Varese, 21100, Italy. alexsquizzo@libero.it, alessandro.squizzato@uninsubria.it.

Editorial group: Cochrane Heart Group.

Publication status and date: New search for studies and content updated (no change to conclusions), published in Issue 12, 2017.

Citation: Squizzato A, Bellesini M, Takeda A, Middeldorp S, Donadini MP. Clopidogrel plus aspirin versus aspirin alone for preventing cardiovascular events. Cochrane Database of Systematic Reviews 2017, Issue 12. Art. No.: CD005158. DOI: 10.1002/14651858.CD005158.pub4.

Copyright ( 2017 The Cochrane Collaboration. Published by John Wiley \& Sons, Ltd.

\section{A B S T R A C T}

\section{Background}

Aspirin is the prophylactic antiplatelet drug of choice for people with cardiovascular disease. Adding a second antiplatelet drug to aspirin may produce additional benefit for people at high risk and people with established cardiovascular disease. This is an update to a previously published review from 2011.

\section{Objectives}

To review the benefit and harm of adding clopidogrel to aspirin therapy for preventing cardiovascular events in people who have coronary disease, ischaemic cerebrovascular disease, peripheral arterial disease, or were at high risk of atherothrombotic disease, but did not have a coronary stent.

\section{Search methods}

We updated the searches of CENTRAL (2017, Issue 6), MEDLINE (Ovid, 1946 to 4 July 2017) and Embase (Ovid, 1947 to 3 July 2017 ) on 4 July 2017. We also searched ClinicalTrials.gov and the WHO ICTRP portal, and handsearched reference lists. We applied no language restrictions.

\section{Selection criteria}

We included all randomised controlled trials comparing over 30 days use of aspirin plus clopidogrel with aspirin plus placebo or aspirin alone in people with coronary disease, ischaemic cerebrovascular disease, peripheral arterial disease, or at high risk of atherothrombotic disease. We excluded studies including only people with coronary drug-eluting stent (DES) or non-DES, or both.

\section{Data collection and analysis}

We collected data on mortality from cardiovascular causes, all-cause mortality, fatal and non-fatal myocardial infarction, fatal and non-fatal ischaemic stroke, major and minor bleeding. The overall treatment effect was estimated by the pooled risk ratio (RR) with $95 \%$ confidence interval $(\mathrm{Cl})$, using a fixed-effect model (Mantel-Haenszel); we used a random-effects model in cases of moderate or severe heterogeneity $\left(I^{2} \geq 30 \%\right)$. We assessed the quality of the evidence using the GRADE approach. We used GRADE profiler (GRADE Pro) to import data from Review Manager to create a 'Summary of findings' table. 


\section{Main results}

The search identified 13 studies in addition to the two studies in the previous version of our systematic review. Overall, we included data from 15 trials with 33,970 people. We completed a 'Risk of bias' assessment for all studies. The risk of bias was low in four trials because they were at low risk of bias for all key domains (random sequence generation, allocation concealment, blinding, selective outcome reporting and incomplete outcome data), even if some of them were funded by the pharmaceutical industry.

Analysis showed no difference in the effectiveness of aspirin plus clopidogrel in preventing cardiovascular mortality $(\mathrm{RR} 0.98,95 \% \mathrm{Cl} 0.88$ to 1.10; participants $=31,903$; studies $=7$; moderate quality evidence), and no evidence of a difference in all-cause mortality (RR 1.05 , $95 \%$ $\mathrm{Cl} 0.87$ to 1.25 ; participants $=32,908$; studies $=9$; low quality evidence).

There was a lower risk of fatal and non-fatal myocardial infarction with clopidogrel plus aspirin compared with aspirin plus placebo or aspirin alone (RR $0.78,95 \% \mathrm{Cl} 0.69$ to 0.90 ; participants $=16,175$; studies $=6$; moderate quality evidence). There was a reduction in the risk of fatal and non-fatal ischaemic stroke (RR $0.73,95 \% \mathrm{Cl} 0.59$ to 0.91 ; participants = 4006; studies = 5; moderate quality evidence).

However, there was a higher risk of major bleeding with clopidogrel plus aspirin compared with aspirin plus placebo or aspirin alone (RR $1.44,95 \% \mathrm{Cl} 1.25$ to 1.64 ; participants $=33,300$; studies $=10$; moderate quality evidence) and of minor bleeding $(\mathrm{RR} 2.03,95 \% \mathrm{Cl} 1.75$ to 2.36; participants $=14,731 ;$ studies $=8$; moderate quality evidence).

Overall, we would expect 13 myocardial infarctions and 23 ischaemic strokes be prevented for every 1000 patients treated with the combination in a median follow-up period of 12 months, but 9 major bleeds and 33 minor bleeds would be caused during a median followup period of 10.5 and 6 months, respectively.

\section{Authors' conclusions}

The available evidence demonstrates that the use of clopidogrel plus aspirin in people at high risk of cardiovascular disease and people with established cardiovascular disease without a coronary stent is associated with a reduction in the risk of myocardial infarction and ischaemic stroke, and an increased risk of major and minor bleeding compared with aspirin alone. According to GRADE criteria, the quality of evidence was moderate for all outcomes except all-cause mortality (low quality evidence) and adverse events (very low quality evidence).

\section{PLAIN LANGUAGE SUMMARY}

\section{Clopidogrel plus aspirin versus aspirin alone for preventing cardiovascular events}

\section{Question}

We reviewed the evidence about the effect of clopidogrel and aspirin in people at high risk of getting heart disease or having a stroke, and in those who already have heart disease.

\section{Background}

Aspirin is widely used to prevent heart disease, but the effects for people at high risk of getting heart disease are small. We wanted to find out whether taking clopidogrel (which is also used to prevent heart disease) and aspirin is better to prevent getting heart disease or having a stroke than taking aspirin alone. We also wanted to find out if people who already had heart disease were at less risk of dying, having a heart attack or stroke if they took clopidogrel and aspirin.

\section{Study characteristics}

This review contains evidence up to July 2017. We found 15 studies which together included more than 30,000 people at high risk of heart disease who are taking aspirin. All studies randomly assigned participants to the intervention group (taking aspirin and clopidogrel) or the control group (taking aspirin and placebo (a pretend treatment that has no effect). Participants took clopidogrel between six weeks and 3.4 years, depending on the study they took part in.

The results do not apply to people with recent placement of coronary stents (tubes inserted in the blood vessel to keep it open), who were excluded from this review.

\section{Key results}

The results showed that there is a benefit of adding clopidogrel to aspirin in terms of reducing the risk of heart attack or stroke. However, there is a higher risk of major and minor bleeding associated with this. There was no effect on death due to heart problems or death from any cause.

\section{Quality of the evidence}

Using Cochrane criteria, four trials were at low risk of bias. 
Using GRADE standards, the quality of published evidence was moderate for most results, but low for death from any cause and very low for side effects. 


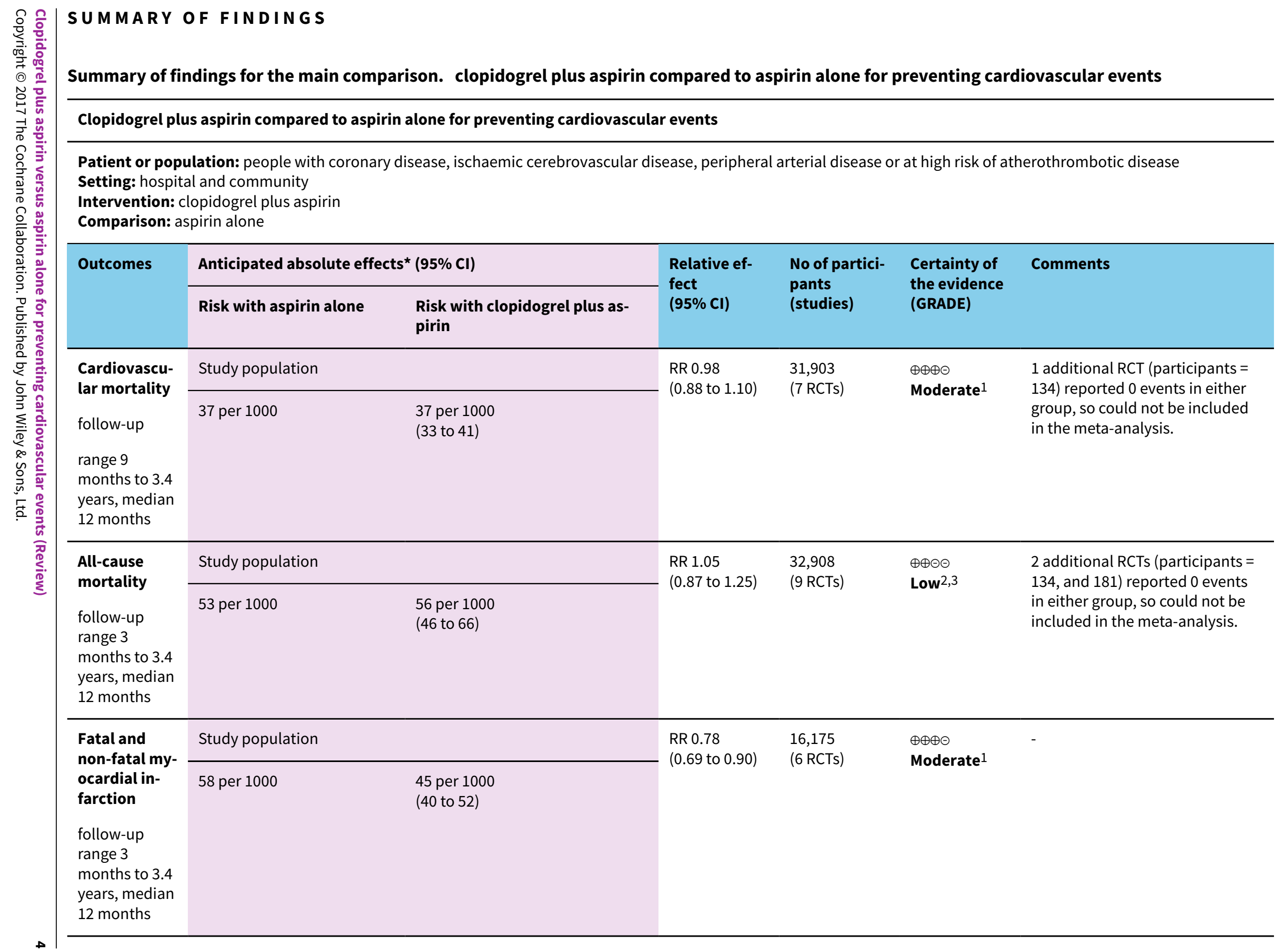
Setting: hospital and community

: clopidogrel plus aspirin 


\begin{tabular}{|c|c|c|c|c|c|c|}
\hline \multirow{2}{*}{ 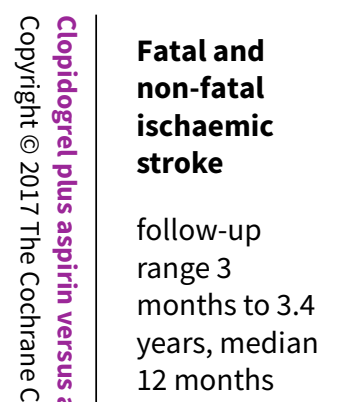 } & \multicolumn{2}{|c|}{ Study population } & \multirow{2}{*}{$\begin{array}{l}\text { RR } 0.73 \\
\text { (0.59 to } 0.91 \text { ) }\end{array}$} & \multirow{2}{*}{$\begin{array}{l}4006 \\
\text { (5 RCTs) }\end{array}$} & \multirow{2}{*}{$\begin{array}{l}\oplus \oplus \oplus \ominus \\
\text { Moderate }^{4}\end{array}$} & \multirow[t]{2}{*}{-} \\
\hline & 86 per 1000 & $\begin{array}{l}63 \text { per } 1000 \\
(51 \text { to } 78)\end{array}$ & & & & \\
\hline 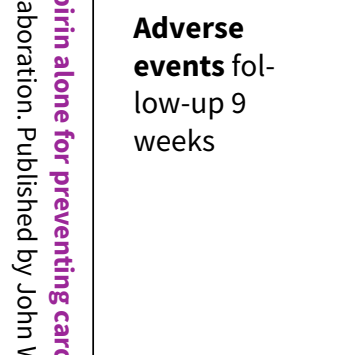 & \multicolumn{2}{|c|}{$\begin{array}{l}\text { Only } 1 \text { study reported adverse events. In the PROCLAIM study, } \\
\text { approximately half of the participants in each study arm expe- } \\
\text { rienced an adverse event: gastrointestinal disorders, infections } \\
\text { and infestations were the most commonly reported (17\% in the } \\
\text { clopidogrel group and } 9 \% \text { in the placebo group). Minor adverse } \\
\text { events reported in the clopidogrel plus aspirin group included } \\
\text { immune hypersensitivity, seasonal allergy, haematuria and re- } \\
\text { nal failure; in the placebo plus aspirin group included peripheral } \\
\text { oedema, cardiac palpitations, dyslipidaemia and spinal stenosis. }\end{array}$} & - & $\begin{array}{l}181 \\
(1 \mathrm{RCT})\end{array}$ & $\begin{array}{l}\oplus \odot \Theta \odot \\
\text { Very low } 1,7,8\end{array}$ & - \\
\hline Major bleed- & \multicolumn{2}{|c|}{ Study population } & \multirow{2}{*}{$\begin{array}{l}\text { RR } 1.44 \\
\text { (1.25 to } 1.64 \text { ) }\end{array}$} & \multirow{2}{*}{$\begin{array}{l}33,300 \\
\text { (10 RCTs) }\end{array}$} & \multirow{2}{*}{$\begin{array}{l}\oplus \oplus \oplus \ominus \\
\text { Moderate }^{5}\end{array}$} & \multirow{2}{*}{$\begin{array}{l}3 \text { additional RCTs (participants } \\
=20,134 \text { and } 181 \text { ) reported } 0 \\
\text { events in either group, so could } \\
\text { not be included in the meta- } \\
\text { analysis. }\end{array}$} \\
\hline 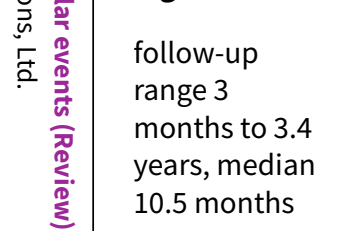 & 21 per 1000 & $\begin{array}{l}30 \text { per } 1000 \\
\text { (26 to } 34)\end{array}$ & & & & \\
\hline \multirow{2}{*}{$\begin{array}{l}\text { Minor bleed- } \\
\text { ing } \\
\text { follow-up } \\
\text { range } 3 \\
\text { months to } 12 \\
\text { months, me- } \\
\text { dian } 6 \text { months }\end{array}$} & \multicolumn{2}{|c|}{ Study population } & \multirow{2}{*}{$\begin{array}{l}\text { RR } 2.03 \\
\text { (1.75 to } 2.36 \text { ) }\end{array}$} & \multirow{2}{*}{$\begin{array}{l}14,731 \\
\text { (8 RCTs) }\end{array}$} & \multirow{2}{*}{$\begin{array}{l}\oplus \oplus \oplus \ominus \\
\text { Moderate }^{6}\end{array}$} & \multirow{2}{*}{$\begin{array}{l}1 \text { additional } \mathrm{RCT} \text { (participants = } \\
20 \text { ) reported } 0 \text { events in either } \\
\text { group, so could not be included } \\
\text { in the meta-analysis. }\end{array}$} \\
\hline & 32 per 1000 & $\begin{array}{l}65 \text { per } 1000 \\
(56 \text { to } 76)\end{array}$ & & & & \\
\hline
\end{tabular}

${ }^{\star}$ The risk in the intervention group (and its $95 \%$ confidence interval) is based on the assumed risk in the comparison group and the relative effect of the intervention (and its $95 \% \mathrm{Cl})$.

Cl: confidence interval; $\mathbf{R C T}$ : randomized controlled trial; RR: risk ratio.

\section{GRADE Working Group grades of evidence}

High certainty: We are very confident that the true effect lies close to that of the estimate of the effect 
Moderate certainty: We are moderately confident in the effect estimate: The true effect is likely to be close to the estimate of the effect, but there is a possibility that it is substantially different

Low certainty: Our confidence in the effect estimate is limited: The true effect may be substantially different from the estimate of the effect

Very low certainty: We have very little confidence in the effect estimate: The true effect is likely to be substantially different from the estimate of effect

${ }^{1}$ There were insufficient studies for a funnel plot, but publication bias was strongly suspected as this important outcome could be expected to be more widely reported. Downgraded by one level.

2Downgraded by one level for imprecision due to confidence interval that included both null effect and appreciable benefit/harm.

${ }^{3}$ Although there were technically too few studies for a funnel plot (nine rather than 10 ), the tentative funnel plot was asymmetric and suggestive of publication bias. This important outcome was not reported by as many studies as would be expected, so we have downgraded by one level for strongly suspected publication bias.

${ }^{4}$ Downgraded by one level for risk of bias; some concerns over blinding, random sequence generation and allocation concealment.

${ }^{5}$ Downgraded by one level for publication bias; funnel plot asymmetric.

${ }^{6}$ Although there were too few studies for a funnel plot (eight rather than 10), the tentative funnel plot was asymmetric and suggestive of publication bias. This important outcome was not reported by as many studies as would be expected, so we have downgraded by one level for strongly suspected publication bias.

${ }^{7}$ Downgraded by one level for indirectness, as the only study reporting adverse events had a mixed population.

8 Downgraded by one level for imprecision, due to very low number of participants. 


\section{B A C K G R O U N D}

\section{Description of the condition}

Cardiovascular disease is a leading cause of mortality and morbidity worldwide (AHA Statistical Update 2017; European Heart Network 2017). An estimated 17.7 million people die of cardiovascular disease each year (2015 figures) (WHO 2016). Primary and secondary prophylaxis aims to modify major risk factors. Antiplatelet therapy improves the survival of people with manifest cardiovascular disease (Patrono 2011).

Aspirin (acetylsalicylic acid) as antiplatelet therapy is the drug of choice due to its good cost-effectiveness profile (Gaspoz 2002). Based on one meta-analysis, the Antithrombotic Trialists' Collaboration (ATC) concluded that aspirin is protective in most people at risk of cardiovascular events. In this analysis, people at risk were those with acute myocardial infarction or ischaemic stroke, unstable or stable angina, previous myocardial infarction, stroke or cerebral ischaemia, peripheral arterial disease or atrial fibrillation (ATC 2009)

\section{Description of the intervention}

Several molecules that inhibit platelet aggregation are currently available in clinical practice, in particular the old (ticlopidine, clopidogrel) and the new (prasugrel, ticagrelor) P2Y12 inhibitors (ACCP 2012). Previously published reviews and protocols in the Cochrane Library discussed the importance of antiplatelet drugs and their limits in the prevention of cardiovascular disease, mainly in peripheral artery disease (Bedenis 2014; Bedenis 2015; Cosmi 2001; Dorffler-Melly 2003a; Dorffler-Melly 2003b; DorfflerMelly 2005; Geraghty 2011; Hankey 2004; Robertson 2012; Robless 2003; Robless 2007; Sudlow 2009; Valentine 2012; Wong 2011). Adding a second antiplatelet drug to aspirin may produce additional benefits in some clinical circumstances (ATC 2009) by inhibiting platelets by two different mechanisms. Aspirin has an antiplatelet effect by inhibiting the production of thromboxane, whereas other antiplatelet drugs are adenosine diphosphate (ADP) receptor/P2Y12 inhibitors. Worldwide, clopidogrel is the most frequently used P2Y12 inhibitor for cardiovascular disease prevention. Clopidogrel has been clinically compared with aspirin (CAPRIE 1996), and combined with aspirin (CREDO 2002; CURE 2001), and demonstrated a good safety profile in these studies.

\section{How the intervention might work}

The combination treatment of clopidogrel plus aspirin could be a potential strategy to reduce cardiovascular disease because, although the relative risk reduction of death, myocardial infarction and stroke in people receiving aspirin was approximately $20 \%$ (ATC 2009), the protection with a single antiplatelet therapy in people with a high risk of cardiovascular disease remains unsatisfactory in absolute terms. Moreover, low compliance and adverse effects limit the cost effectiveness of aspirin alone (Morant 2003). As confirmed by one systematic review and economic evaluation conducted on behalf of the UK National Institute for Health and Care Excellence (NICE), it was suggested that people with non-ST segment elevation acute coronary syndrome benefit from aspirin in combination with clopidogrel compared to treatment with aspirin alone (Main 2004; NICE 2004). Given that the antiplatelet effect is consistent in different populations, any age, sex and risk subgroups could derive benefit from the combination therapy.

\section{Why it is important to do this review}

Clopidogrel has a good safety profile but it has several adverse effects that should be balanced with the potential beneficial effects. Besides bleeding associated with combined antiplatelet use, additional adverse effects for clopidogrel include diarrhoea, abdominal pain and dyspepsia, which are common. Moreover, some rare, but potentially severe complications need to be considered. Indeed, thienopyridines can provoke potentially severe neutropenia (Hankey 2004), although the risk is lower with clopidogrel compared to ticlopidine (CAPRIE 1996). Finally, clopidogrel-associated thrombotic thrombocytopenic purpura (TTP), albeit rare, is associated with high mortality if not treated promptly (Zakarija 2004).

The aim of this systematic review, an update of a previously published Cochrane Review (Squizzato 2011), was to assess the effects of the combination of clopidogrel and aspirin compared with aspirin alone in the primary and secondary prevention of cardiovascular disease.

\section{OB JECTIVES}

To review the benefit and harm of adding clopidogrel to aspirin therapy for preventing cardiovascular events in people who have coronary disease, ischaemic cerebrovascular disease, peripheral arterial disease, or were at high risk of atherothrombotic disease, but do not have a coronary stent.

\section{METHODS}

\section{Criteria for considering studies for this review \\ Types of studies}

Randomized controlled trials (RCTs) comparing the use of aspirin plus clopidogrel with aspirin plus placebo or aspirin alone. Studies on the optimal duration of clopidogrel plus aspirin therapy in people with coronary drug-eluting stent (DES) or non-DES (or both) were excluded, because this was beyond the aim of this review. Moreover, the clinical decision after coronary stenting is not focused on whether or not adding clopidogrel to aspirin (i.e. regularly performed for an initial variable period), but on the optimal timing of clopidogrel interruption.

\section{Types of participants}

Participants with coronary disease, ischaemic cerebrovascular disease, peripheral arterial disease, or were at high risk of atherothrombotic disease (e.g. due to having hypertension, metabolic syndrome or high-risk lifestyle factors). We excluded people who had a coronary stent.

\section{Types of interventions}

Aspirin plus clopidogrel versus aspirin plus placebo or aspirin alone, administered for more than 30 days. No other platelet aggregation inhibitors as co-intervention were accepted.

\section{Types of outcome measures}

The observation and follow-up period had to be at least 30 days.

\section{Primary outcomes}

- Cardiovascular mortality. 
- All-cause mortality.

- Fatal and non-fatal myocardial infarction.

- Fatal and non-fatal ischaemic stroke.

- Adverse events (i.e. renal failure, thrombotic thrombocytopenic purpura (TTP), neutropenia, low platelets, gastric complaints, diarrhoea, skin rash).

\section{Secondary outcomes}

- Major bleeding (fatal bleeding, haemorrhagic stroke, gastric bleeding, any bleeding requiring blood transfusion, any bleeding causing a haemoglobin level drop of greater than $2 \mathrm{mg}$ / $\mathrm{dL}$, or hospitalization).

- Minor bleeding (all non-major bleeds were considered minor bleeds).

- Heart failure.

\section{Additional outcomes}

A post-hoc decision was made to report:

- repeated revascularization;

- saphenous vein graft (SVG) patency;

- amputation;

as these were reported by some studies and were thought to be relevant in terms of quality of life.

We considered any RCTs with at least one of the above clinical outcomes for this review. We extracted only data that occurred during the randomization period. We excluded RCTs with only laboratory outcomes.

We contacted investigators to obtain unpublished data when necessary.

\section{Search methods for identification of studies}

\section{Electronic searches}

We searched the following databases on 4 July 2017 to identify reports of relevant RCTs published since the last review:

- Cochrane Central Register of Controlled Trials (CENTRAL, 2017, Issue 6) in the Cochrane Library;

- MEDLINE (Ovid, 1946 to 4 July 2017);

- Embase Classic and Embase (Ovid, 1947 to 3 July 2017).

The search strategies used previously (Appendix 1 and Appendix 2) were updated for the search in July 2017 (Appendix 3). In particular, the sensitivity-maximizing RCT filter was updated for MEDLINE and Embase (Lefebvre 2011).

We applied no language restrictions.

\section{Searching other resources}

We searched the Database of Abstracts of Reviews of Effects (DARE, 2016 , Issue 3) in the Cochrane Library in July 2017. We also searched www.clinicaltrials.gov for recent or ongoing trials in July 2017; and the World Health Organization (WHO) International Clinical Trials Registry Platform (ICTRP) in October 2017. For both, we used the search terms: "aspirin", "clopidogrel" and "prevention." In addition, we performed an extensive manual search, checking references from original articles and pertinent reviews.

\section{Data collection and analysis}

\section{Selection of studies}

We selected studies on the basis of guidelines given in Chapter 7 of the Cochrane Handbook for Systematic Reviews of Interventions (Higgins 2011a). Two review authors (TK and AS in the first version, MPD and MB in this updated version) independently selected potentially eligible references from the search. They rejected references if it could be determined from the title or abstract (or both) that the study was not suitable for inclusion in this review. We obtained the full text of the study when an article could not be excluded with certainty. We compared excluded studies and resolved disagreements through discussion.

A third review author (SM in the first version and AS in this updated version) checked assessments for the included studies.

\section{Data extraction and management}

We extracted data using a predefined extraction form. We extracted no combined endpoints.

We contacted authors to request additional unpublished data. We extracted data for all groups and subgroups together: coronary disease, ischaemic cerebrovascular disease, peripheral arterial disease, or people at high risk of atherothrombotic disease.

Extracted data included:

- general information: published/unpublished, title, authors, source, country, year of publication, duplicate publications;

- trial characteristics: design, duration, randomisation (and method), allocation concealment (and method), blinding (outcome assessors), checking of blinding;

- intervention: loading dose, dosage, duration of treatment;

- participants: exclusion criteria, total number and number in comparison groups, gender/age, similarity of groups at baseline, withdrawals/losses to follow-up;

- outcome: mortality from myocardial infarction, non-fatal myocardial infarction, unstable angina, heart failure, mortality from stroke, non-fatal stroke, revascularizations, all-cause mortality, major bleeding (haemorrhagic stroke, gastric bleeding, any bleeding requiring blood transfusion, any bleeding causing haemoglobin level drop of greater than $2 \mathrm{mg} /$ $\mathrm{dL}$ ), minor bleeding, all adverse events (i.e. renal failure, TTP, neutropenia, low platelets, gastric complains, diarrhoea, skin rash).

Revascularization procedures were excluded from the primary outcome to reduce the potential for bias. Many episodes of acute coronary events would have been followed by revascularization, leading to double counting of outcomes.

\section{Assessment of risk of bias in included studies}

We assessed the methodological quality of selected studies on the basis of guidelines in Chapter 8 of the Cochrane Handbook for Systematic Reviews of Interventions (Higgins 2011b). We scored each of the following points as 'low,' 'high' or 'unclear' (where 'low' indicated that the study was less open to bias) and reported them in a 'Risk of bias' table (Characteristics of included studies table):

- method of randomisation (selection bias); 
- concealment of allocation (selection bias);

- blinding of investigators and participants (performance bias);

- blinding of outcome assessment (detection bias);

- incomplete outcome data (attrition bias);

- selective reporting (reporting bias);

- other possible bias. In particular, if study was pharmaceutical industry funded.

A study was judged at low risk of bias if all key domains were judged at low risk of bias; a study was judged at high risk of bias if one or more key domains were judged at high risk of bias; a study was judged at unclear risk of bias if one or more key domains were at unclear risk and none at high risk. 'Pharmaceutical industry funded' was not a sufficient criterion to judge a study at high risk of overall bias, so sensitivity analysis was based on the overall assessment of randomization, concealment of allocation, blinding, incomplete outcome data and selective reporting.

To avoid selection bias, we did not reject studies because of methodological characteristics or any subjective quality criteria, except non-randomized studies. However, we planned to examine differences in study methods in sensitivity analyses.

\section{Measures of treatment effect}

We analyzed data of selected studies on the basis of guidelines from Chapter 9 of the Cochrane Handbook for Systematic Reviews of Interventions (Deeks 2011). We used risk ratios (RR) with 95\% confidence intervals $(\mathrm{Cl})$ to analyse dichotomous data. None of our included studies reported continuous data.

We used the Cochrane Review Manager 5 software to analyse the data (RevMan 2014). We based quantitative analysis of outcome on the intention-to-treat (ITT) principle.

\section{Unit of analysis issues}

We planned to manage data with non-standard designs according to guidelines from the Cochrane Handbook for Systematic Reviews of Interventions (Higgins 2011a). None of the included studies were cluster randomized trials, and the only multiarm study had only one intervention arm that used a recommended dose (Zuo 2017). Therefore, we excluded the non-standard dose arm.

\section{Dealing with missing data}

We contacted study investigators to request additional information about missing data, but only three authors provided extra data (CREDO 2002; CRYSSA 2012; ONSET/OFFSET 2010). We decided to analyse only available outcomes for all studies, as imputing the missing data with replacement values would have provided misleading information.

\section{Assessment of heterogeneity}

As trials were carried out according to different protocols, we planned to assess statistical heterogeneity of trial data by using the Mantel-Haenszel $\mathrm{Chi}^{2}$ test of heterogeneity and the $1^{2}$ statistic of heterogeneity (Deeks 2011). For the first method, trial data were considered to be heterogeneous if $P$ was less than 0.10 . As significant heterogeneity may have occurred, we planned to attempt to explain the differences as they related to types of participants and study design. The 12 method is expressed as a percentage of total variation across studies with an uncertainty interval. We used the guidelines on interpretation from the Cochrane Handbook for Systematic Reviews of Interventions (Deeks 2011), which suggest that an 12 statistic of $0 \%$ to $40 \%$ might not be important, $30 \%$ to $60 \%$ may represent moderate heterogeneity, $50 \%$ to $90 \%$ substantial heterogeneity and $75 \%$ to $100 \%$ considerable heterogeneity. In considering the 12 value, we took into account the magnitude and direction of effect, and the strength of evidence for heterogeneity.

\section{Assessment of reporting biases}

We assessed publication bias by using funnel plots when there were more than 10 studies reporting the outcome (Egger 1997).

\section{Data synthesis}

We only undertook meta-analyses where the treatments, participants and underlying clinical questions were similar enough for pooling to be meaningful. The overall treatment effect was estimated by the pooled RR with $95 \% \mathrm{Cl}$ using a fixed-effect model (Mantel-Haenszel). Each test for significance was two-tailed. A random-effects model was used in cases of moderate or severe heterogeneity $(12 \geq 30 \%)$.

\section{Subgroup analysis and investigation of heterogeneity}

The main value of this review is in examining whether administration of clopidogrel has a consistency of effect across all participants, but subgroup analyses were performed to assess the benefit in particular predefined subgroups. The following subgroups analyses were planned:

- male and female;

- elderly (65 years of age or over);

- population - people with the following conditions:

* acute coronary syndrome with or without ST elevation;

* coronary artery bypass grafting;

* ischaemic stroke;

* transient ischaemic attack (TIA);

* peripheral arterial disease undergoing or not undergoing revascularization procedures;

* mixed population.

We retrieved sufficient data to perform only four predefined subgroup analyses: acute coronary syndrome without ST elevation, coronary artery bypass grafting, peripheral arterial disease undergoing revascularization procedures and ischaemic stroke.

\section{Sensitivity analysis}

We reanalyzed data using a random-effects model instead of a fixed-effect model. A random-effects model was prevalently used in case of moderate or severe heterogeneity $\left(1^{2} \geq 30 \%\right)$.

We also conducted a sensitivity analysis restricting the analysis to just those studies assessed to be at overall low risk of bias in the key domains, as described in Assessment of risk of bias in included studies.

\section{'Summary of findings' table}

We used the five GRADE considerations (risk of bias, inconsistency, imprecision, indirectness and publication bias) to assess the quality of the studies that contributed data to the meta-analyses 
for key outcomes, with two review authors agreeing decisions to downgrade. We presented the quality of evidence concerning the main findings of the review results for primary and secondary outcomes in Summary of findings for the main comparison, according to the GRADE principles as described by Higgins 2011b and Atkins 2004. We used GRADEprofiler (GRADEpro) software to assist in the preparation of the 'Summary of findings' table.

\section{RE S U L T S}

\section{Description of studies}

\section{Results of the search}

In the previous search of May 2006, we found 1927 references and of September 2009, we found 3120 references. Based on title or abstract (or both), we excluded 4798 references because they were not RCTs, were duplicates or investigated different topics, 55 references that tested a non-eligible intervention, 129 references that tested a non-eligible population and 35 references that included only data on acute administration (less than 30 days).

In the updated search in July 2017, we identified 8772 references (Figure 1) through databases searching and three extra papers by using other resources (Searching other resources) (PRODIGY 2012; RESET 2012). We retrieved full-text copies of 82 articles. We excluded 38 because they did not meet the inclusion criteria (Characteristics of excluded studies table), and 13 because they were sub-analyses of four excluded studies (CARESS 2005; CHANCE 2013; CLAIR 2010; CREDO 2002). One ongoing study, which was potentially eligible, was identified from a search of the online trial registry (Characteristics of ongoing studies table). Of the 30 included papers, 15 were sub-analyses of four included and analysed studies (CASCADE 2010; CHARISMA 2006; CURE 2001; MIRROR 2012). 
Figure 1. Study flow diagram (PRISMA).

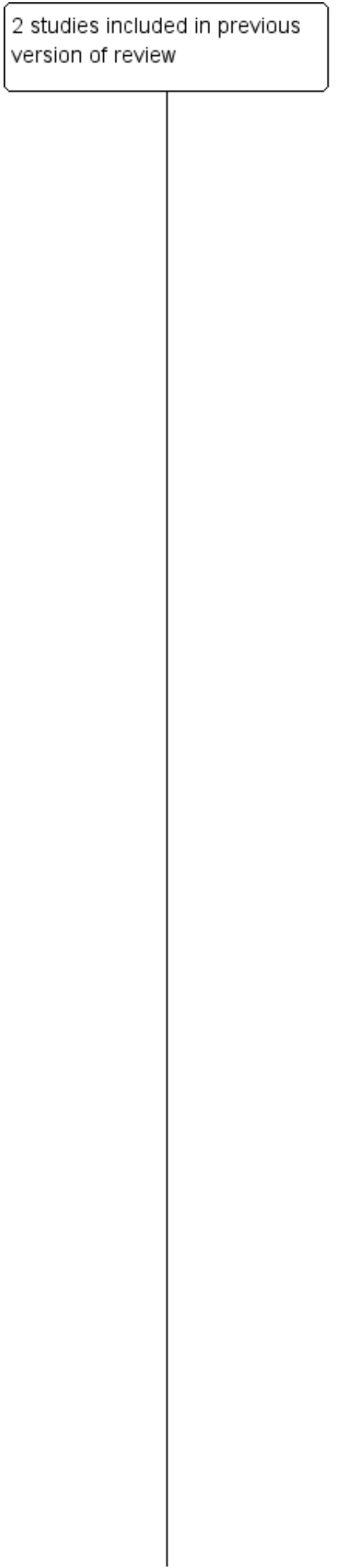

3 additional records identified

\section{through other sources}

searching

(2009-2017)

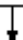

6421 records after duplicates removed

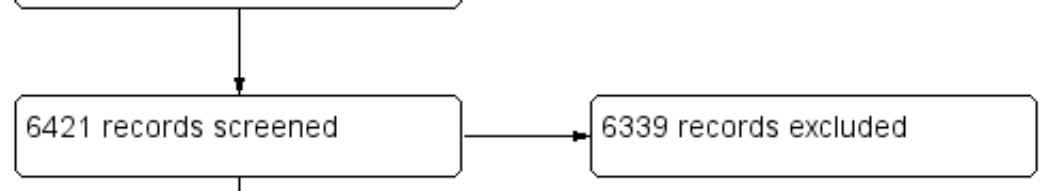

51 full-text articles excluded for not fulfilling the inclusion criteria:

- 10 did not report clinical data;

- 5 included only people with coronary stents;

- 15 had a short ( $<30$ days $)$ duration;

- 2 included only people with transcatheter aortic valve implantation:

- 2 were abstract with only partial data on included participants;

- 4 had no a proper study design;

- 13 were subanalyses. assessed for 1 ongoing study. 
Figure 1. (Continued)

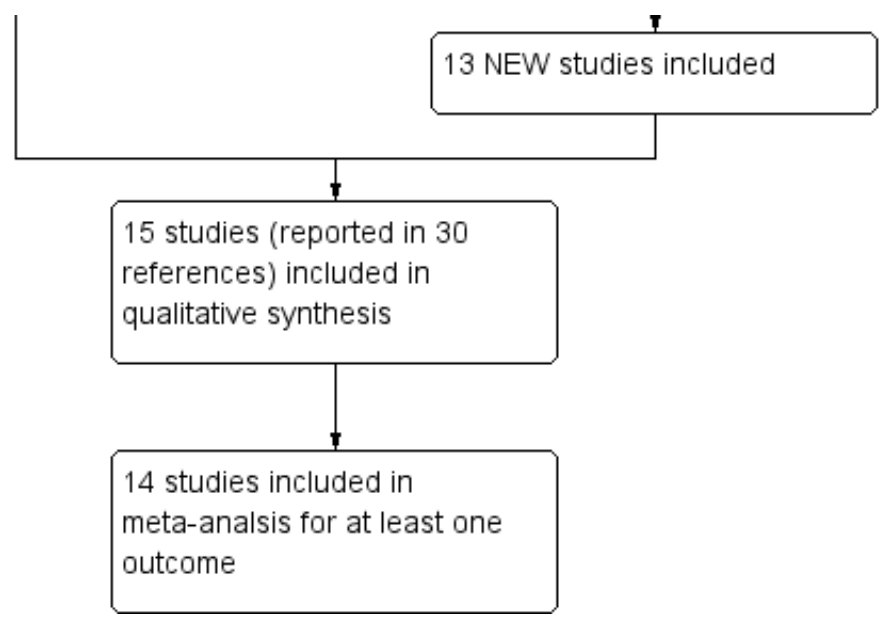

The review included 15 RCTs (ASAP-CABG 2016; CASCADE 2010; CASPAR 2010; CHARISMA 2006; CRYSSA 2012; CURE 2001; FASTER 2007; Gao 2010; Gasparovic 2014; MIRROR 2012; PROCLAIM 2009; SPS3 2012; TEG-CABG; Vavuranakis 2006; Zuo 2017). Therefore, we pooled 12 new studies and a previously excluded study (FASTER 2007) with the two RCTs (CHARISMA 2006; CURE 2001) included in the previous version of our systematic review (Squizzato 2011). The FASTER study was previously excluded because it did not provide enough data to be meta-analysed with the other included studies and included only people with an acute cerebrovascular event (FASTER 2007). It has now been included in the metaanalysis as other trials now report data for people with an acute cerebrovascular event.

We contacted all authors, but only $\mathrm{Dr}$ Mannacio provided additional data (CRYSSA 2012). As only the CHARISMA study randomised people with multiple risk factors but without evidence of cardiovascular disease, as part of a mixed population that also included people with clinically evident atherothrombosis, we could not compare the efficacy of treatment in primary versus secondary prevention.

\section{Included studies}

\section{Year and country}

Studies were published between 2001 and 2017 (CURE 2001; TEG CABG). Seven studies were monocentric: they were conducted in Italy (CRYSSA 2012), China (Gao 2010; Zuo 2017), Greece (Vavuranakis 2006), Croatia (Gasparovic 2014), Texas (USA) (ASAPCABG 2016), and Denmark (TEG-CABG). Three studies were multicentre but were conducted in a single nation: Canada (CASCADE 2010), Germany (MIRROR 2012), and the USA (PROCLAIM 2009). The other studies were both multicentre and international (CASPAR 2010; CHARISMA 2006; CURE 2001; FASTER 2007; SPS3 2012).

\section{Population}

Total numbers of participants in each study range from 20 (ASAPCABG 2016) to 15,603 (CHARISMA 2006). The CHARISMA study included people at high risk of cardiovascular event (CHARISMA 2006); the PROCLAIM study included people with metabolic syndrome and a previous cardiovascular event (PROCLAIM 2009); the CURE and Vavuranakis and collaborators' study included people with a non-ST elevation acute coronary syndrome (CURE
2001; Vavuranakis 2006); the FASTER, SPS3, and Zuo and collaborators' studies included people with a recent ischaemic stroke (FASTER 2007; SPS3 2012; Zuo 2017); the ASAP-CABG, CASCADE, CRYSSA, Gao and collaborators, Gasparovic and collaborators and TEG-CABG study included people undergoing a coronary bypass surgery (ASAP-CABG 2016; CASCADE 2010; CRYSSA 2012; Gao 2010; Gasparovic 2014; TEG-CABG); the CASPAR and MIRROR studies included people with peripheral arterial disease undergoing a revascularization procedure (CASPAR 2010; MIRROR 2012).

\section{Clopidogrel and aspirin dosage}

The daily dose of clopidogrel was $75 \mathrm{mg}$, except for one study at $100 \mathrm{mg}$ (Vavuranakis 2006). We excluded the $50 \mathrm{mg}$ arm of the Zuo and collaborators' study from the analysis as this is not the recommended dose (Zuo 2017). Aspirin daily doses varied from 70 mg (CHARISMA 2006) to 325 mg (ASAP-CABG 2016; CURE 2001; SPS3 2012). Six studies had no placebo in the control group (CRYSSA 2012; Gao 2010; Gasparovic 2014; TEG-CABG; Vavuranakis 2006; Zuo 2017).

Therapy was for a minimum of six weeks (PROCLAIM 2009) to a maximum of 3.4 years (mean; range 0 to 8.2 years) (SPS3 2012). In addition to the SPS3 study, only the CHARISMA study had a treatment duration of more than year (median 28 months) (CHARISMA 2006).

\section{Detailed description}

A summary of the included studies is shown in Characteristics of included studies table and a full description is provided in Appendix 4.

\section{Excluded studies}

The reasons for exclusion are specified in the Characteristics of excluded studies table. Ten RCTs did not report relevant clinical data, five included only people with coronary stents, 15 had a short (less than 30 days) duration, four had improper study design, two included only people undergoing a transcatheter aortic valve implantation (TAVI) procedure and two were conference abstracts that lacked data (unable to contact authors for further information). 


\section{Risk of bias in included studies}

See Characteristics of included studies table; Figure 2; and Figure 3.

Figure 2. Risk of bias summary: review authors' judgements about each risk of bias item for each included study.

\begin{tabular}{|c|c|c|c|c|c|c|}
\hline & 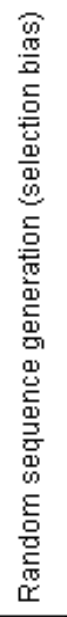 & 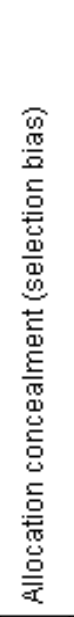 & 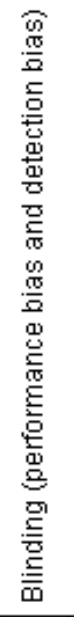 & 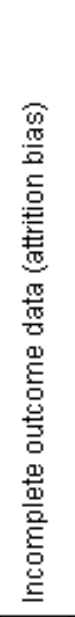 & 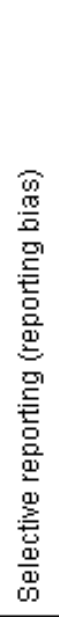 & 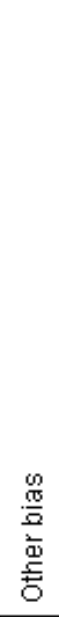 \\
\hline ASAP-CABG 2016 & $?$ & $?$ & + & + & $\oplus$ & 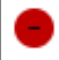 \\
\hline CASCADE 2010 & $\odot$ & $\odot$ & $\odot$ & + & $\oplus$ & $\Theta$ \\
\hline CASPAR 2010 & $\odot$ & $\odot$ & $\odot$ & + & $\oplus$ & $\odot$ \\
\hline CHARISMA 2006 & $\odot$ & + & + & + & $?$ & 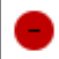 \\
\hline CRYSSA 2012 & + & + & $O$ & + & $?$ & $?$ \\
\hline CURE 2001 & + & + & + & + & $\oplus$ & $\odot$ \\
\hline FASTER 2007 & + & + & + & + & $\oplus$ & + \\
\hline Gao 2010 & $?$ & $?$ & $\theta$ & $\odot$ & $?$ & $\odot$ \\
\hline Gasparovic 2014 & + & + & $O$ & + & + & $?$ \\
\hline MIRROR 2012 & + & $?$ & + & + & + & + \\
\hline PROCLAIM 2009 & + & $?$ & + & + & $?$ & $\odot$ \\
\hline SPS3 2012 & + & + & + & + & $?$ & + \\
\hline TEG-CABG & $?$ & + & - & + & + & + \\
\hline Vavuranakis 2006 & $?$ & $?$ & 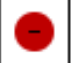 & + & $?$ & + \\
\hline Zuo 2017 & $?$ & $?$ & $\odot$ & + & $?$ & + \\
\hline
\end{tabular}


Figure 3. Risk of bias graph: review authors' judgements about each risk of bias item presented as percentages across all included studies.

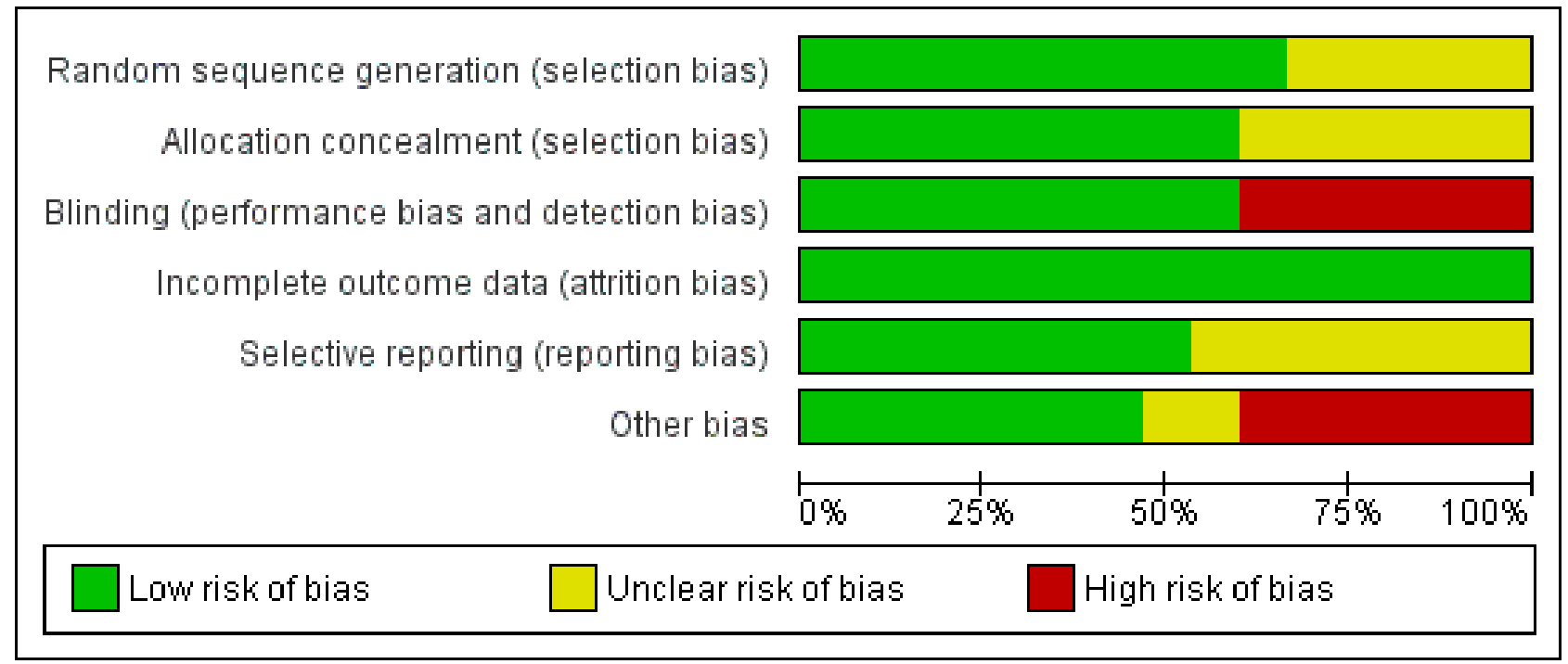

Based on the available data, only the FASTER 2007 trial was at low risk of bias for all domains. The CASCADE 2010, CASPAR 2010, and CURE 2001 studies were potentially at low risk of bias but were trials funded by the pharmaceutical industry. The CRYSSA 2012, Gao 2010, Gasparovic 2014, TEG-CABG, Vavuranakis 2006, and Zuo 2017 studies were at higher risk of bias compared to the other included studies. The ASAP-CABG 2016, MIRROR 2012, and PROCLAIM 2009 studies were judged at unclear risk of bias; with the ASAP-CABG 2016 and PROCLAIM 2009 studies being funded by the pharmaceutical industry.

\section{Allocation}

Ten studies used a random sequence generation was used in 10 studies (CASCADE 2010; CASPAR 2010; CHARISMA 2006; CRYSSA 2012; CURE 2001; FASTER 2007; Gasparovic 2014; MIRROR 2012; PROCLAIM 2009; SPS3 2012). Five studies had insufficient data to judge randomisation (ASAP-CABG 2016; Gao 2010; TEG-CABG; Vavuranakis 2006; Zuo 2017).

Nine studies used adequate allocation concealment (CASCADE 2010; CASPAR 2010; CHARISMA 2006; CRYSSA 2012; CURE 2001; FASTER 2007; Gasparovic 2014; SPS3 2012; TEG-CABG); six studies had insufficient data to judge allocation concealment (ASAP-CABG 2016; Gao 2010; MIRROR 2012; PROCLAIM 2009; Vavuranakis 2006; Zuo 2017).

\section{Blinding}

Nine included studies were double-blinded (ASAP-CABG 2016; CASCADE 2010; CASPAR 2010; CHARISMA 2006; CURE 2001; FASTER 2007; MIRROR 2012; PROCLAIM 2009; SPS3 2012). Six studies had no placebo in the control group (CRYSSA 2012; Gao 2010; Gasparovic 2014; TEG-CABG; Vavuranakis 2006; Zuo 2017).

\section{Incomplete outcome data}

All 15 included trials clearly reported reasons for withdrawals, dropouts, protocol deviations and losses to follow-up.

\section{Selective reporting}

Eleven studies were listed on www.ClinicalTrials.gov so it was possible to compare preplanned outcomes with those reported in the trial publications (ASAP-CABG 2016; CASCADE 2010; CASPAR 2010; CHARISMA 2006; CURE 2001; FASTER 2007; Gao 2010; Gasparovic 2014; MIRROR 2012; SPS3 2012; TEG-CABG). Of these, eight reported results as expected based on available protocol information, so were at low risk of bias (ASAP-CABG 2016; CASCADE 2010; CASPAR 2010; CURE 2001; FASTER 2007; Gasparovic 2014; MIRROR 2012; TEG-CABG). CHARISMA 2006 was at unclear risk of bias as although the primary outcomes were reported as per protocol, the secondary outcomes in the published paper included hospitalisation for unstable angina, TIA or revascularization). Gao 2010 was at unclear risk of bias because the incidence of major bleeding was not reported despite this being a planned outcome. SPS3 2012 was at unclear risk because it was terminated early, so outcomes were not necessarily reported as planned.

We could not find trial protocols for four studies, so these were at unclear risk of bias (CRYSSA 2012; PROCLAIM 2009; Vavuranakis 2006; Zuo 2017).

\section{Other potential sources of bias}

Six studies were funded by the pharmaceutical industry (ASAPCABG 2016; CASCADE 2010; CASPAR 2010; CHARISMA 2006; CURE 2001; PROCLAIM 2009). Two studies had insufficient data available to assess funding bias (CRYSSA 2012; Gasparovic 2014). Three studies, even if partially funded by pharmaceutical industry, were at low risk of bias concerning funding (FASTER 2007; MIRROR 2012; SPS3 2012); four studies did not receive funds from pharmaceutical companies (Gao 2010; TEG-CABG; Vavuranakis 2006; Zuo 2017).

\section{Effects of interventions}

See: Summary of findings for the main comparison clopidogrel plus aspirin compared to aspirin alone for preventing cardiovascular events 
See Summary of findings for the main comparison for the comparison of aspirin plus clopidogrel versus aspirin alone for preventing cardiovascular events in people at high risk of cardiovascular disease and in people with established cardiovascular disease without a coronary stent.

\section{Primary outcomes}

\section{Cardiovascular mortality}

There was no difference between groups in effect on cardiovascular mortality (RR 0.98, 95\% Cl 0.88 to 1.10; participants $=31,903$; studies = 7; moderate quality evidence; Analysis 1.1). One study did not contribute to the meta-analysis as there were no deaths in either group (Zuo 2017; participants $=134$ ). As there was no evidence of heterogeneity, we used a fixed-effect model.

\section{All-cause mortality}

There was no evidence of a difference between groups in effect on all-cause mortality (RR $1.05,95 \% \mathrm{Cl} 0.87$ to 1.25 ; participants $=32,908$; studies = 9; $1^{2}=40 \%$; Analysis 1.2). We used a randomeffects model since the $\mathrm{I}^{2}$ statistic of $40 \%$ may represent moderate heterogeneity. Two studies did not contribute to the meta-analysis as there were no deaths in either treatment group (PROCLAIM 2009, participants $=181$; Zuo 2017, participants $=134)$. Although there were only nine studies rather than the required 10 , a tentative forest plot was suggestive of publication bias (Figure 4).

Figure 4. Funnel plot of comparison: 1 Clopidogrel (Clo) plus aspirin (ASA) versus aspirin alone, outcome: 1.2 Allcause mortality. CABG: coronary artery bypass graft.

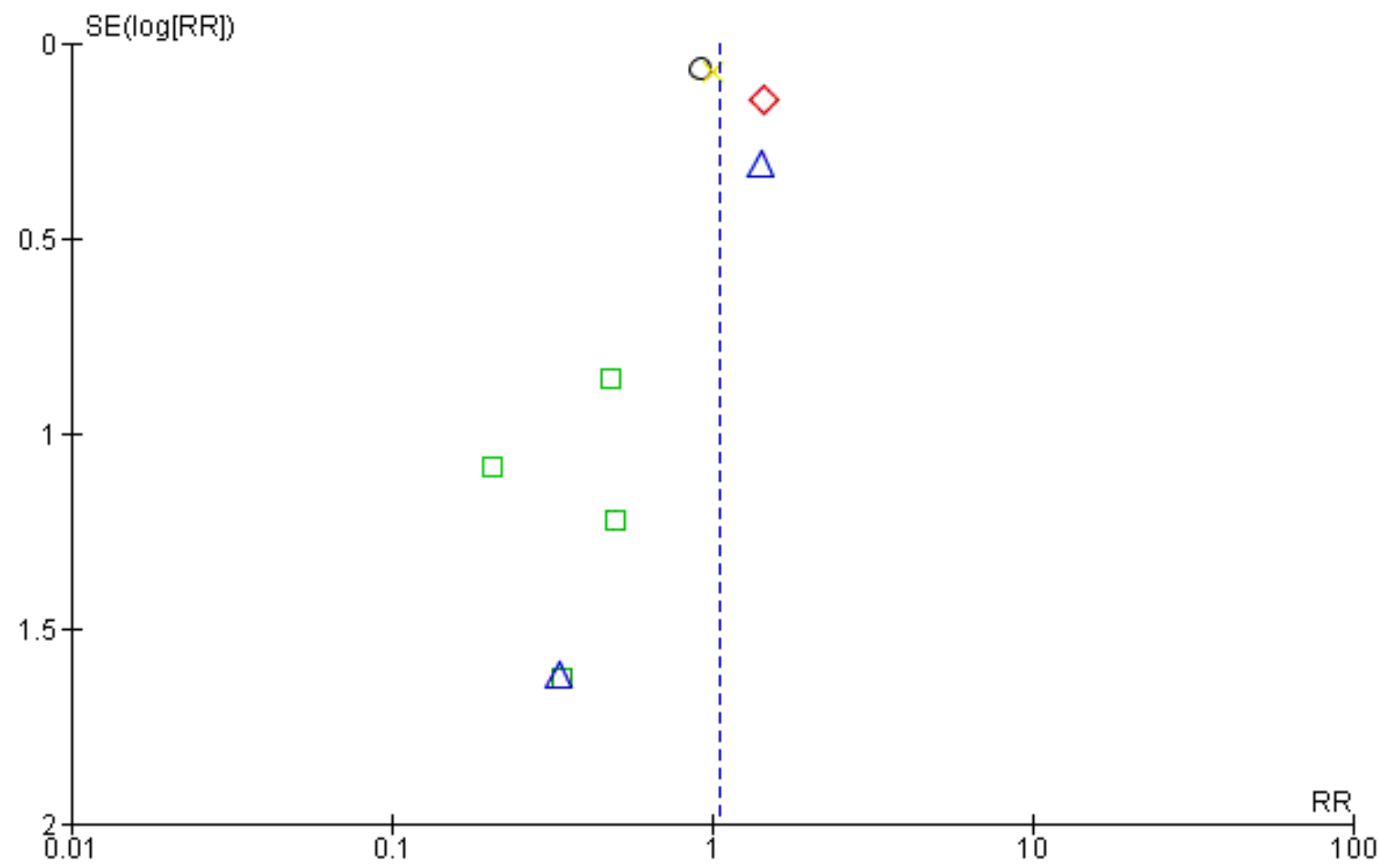

Subgroups

Acute coronary syndrome without ST elevation

Ischaemic stroke

CABG

Peripheral arterial disease (PAD)

Mixed population

\section{Fatal and non-fatal myocardial infarction}

The pooled findings showed that, compared with aspirin alone, clopidogrel plus aspirin was associated with a reduced risk of fatal and non-fatal myocardial infarction (RR $0.78,95 \% \mathrm{Cl} 0.69$ to 0.90 ; participants $=16,175$; studies $=6 ; 1^{2}=0 \%$; moderate quality evidence; Analysis 1.3). As there was no evidence of heterogeneity, we used a fixed-effect model for this meta-analysis. The number needed to treat for an additional beneficial outcome (NNTB) for fatal and non-fatal myocardial infarction was 77 : this means that out of 77 people who take clopidogrel in addition to aspirin, on average one fewer person would be expected to experience a myocardial infarction compared to taking aspirin alone.

\section{Fatal and non-fatal ischaemic stroke}

There was some evidence that the risk of fatal and non-fatal stroke was lower in people taking clopidogrel in addition to aspirin compared with taking aspirin alone (RR $0.73,95 \% \mathrm{Cl} 0.59$ to 
$0.91 ;$ participants $=4006 ;$ studies $=5 ; 1^{2}=20 \%$; moderate quality evidence; Analysis 1.4).

\section{Adverse events}

There was insufficient data (i.e. only one study reporting data) to perform meta-analysis for adverse events (PROCLAIM 2009). In the PROCLAIM study, approximately half of the participants in each study arm experienced an adverse event; gastrointestinal disorders and infections were the most commonly reported $17 \%$ in the clopidogrel group and $9 \%$ in the placebo group). Minor adverse events reported in the clopidogrel plus aspirin group included immune hypersensitivity, seasonal allergy, haematuria and renal failure; in the placebo plus aspirin group included peripheral oedema, cardiac palpitations, dyslipidaemia and spinal stenosis (PROCLAIM 2009). This outcome was assessed as having very low quality of evidence according to GRADE criteria.

\section{Secondary outcomes}

\section{Major bleeding}

There was an increase in major bleeding in people treated with clopidogrel plus aspirin. Compared with aspirin alone, the risk of having major bleeding was $44 \%$ higher in the clopidogrel plus aspirin group (RR 1.44, 95\% Cl 1.25 to 1.64; participants = 33,300; studies $=10 ; 12=0 \%$; moderate quality evidence; Analysis 1.5$)$. Three studies could not be included in the meta-analysis due to having no events in either treatment group (ASAP-CABG 2016: participants = 20; PROCLAIM 2009: participants = 181; Zuo 2017: participants = 134). The number needed to treat to prevent one harmful outcome (NNTH) for major bleeding was 111: this means that for every 111 people taking clopidogrel with aspirin, one extra person could be expected to experience major bleeding compared with people taking aspirin alone. The funnel plot was slightly asymmetric, suggesting publication bias (Figure 5).

Figure 5. Funnel plot of comparison: 1 Clopidogrel (Clo) plus aspirin (ASA) versus aspirin alone, outcome: 1.5 Major bleeding. CABG: coronary artery bypass graft; PAD: peripheral arterial disease.

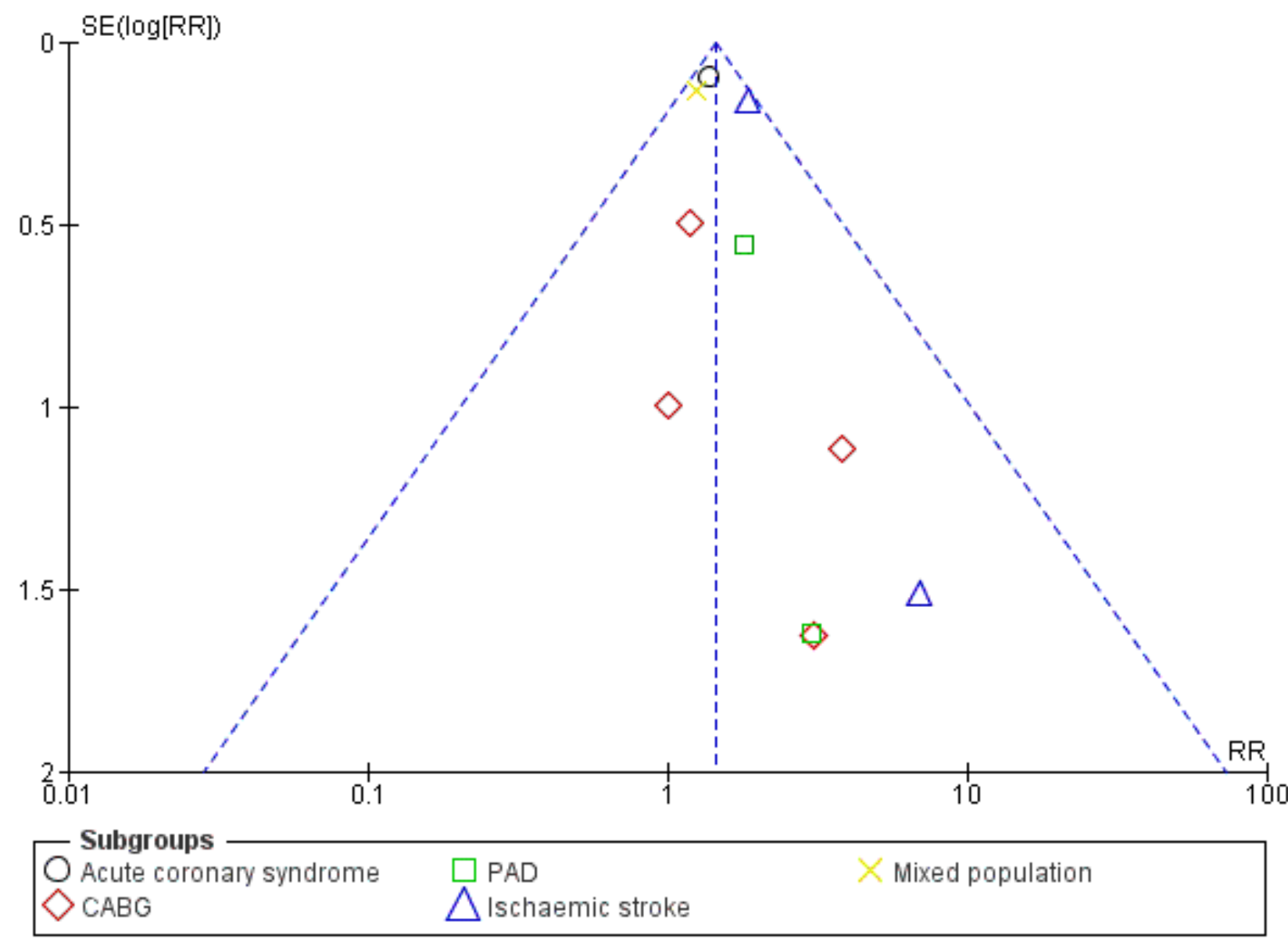

\section{Minor bleeding}

The risk of minor bleeding in people with clopidogrel plus aspirin therapy compared to aspirin alone was increased (RR 2.03, 95\% Cl 1.75 to 2.36 ; participants $=14,731$; studies $=8 ; 12=0 \%$; moderate quality evidence; Analysis 1.6). One study could not be included in the meta-analysis due to having zero events in both arms (ASAP-CABG 2016: participants $=20$ ). Although there were too few studies for a funnel plot, a tentative plot was suggestive of possible publication bias (Figure 6). 
Figure 6. Funnel plot of comparison: 1 Clopidogrel (Clo) plus aspirin (ASA) versus aspirin alone, outcome: 1.6 Minor bleeding. CABG: coronary artery bypass graft; PAD: peripheral arterial disease.

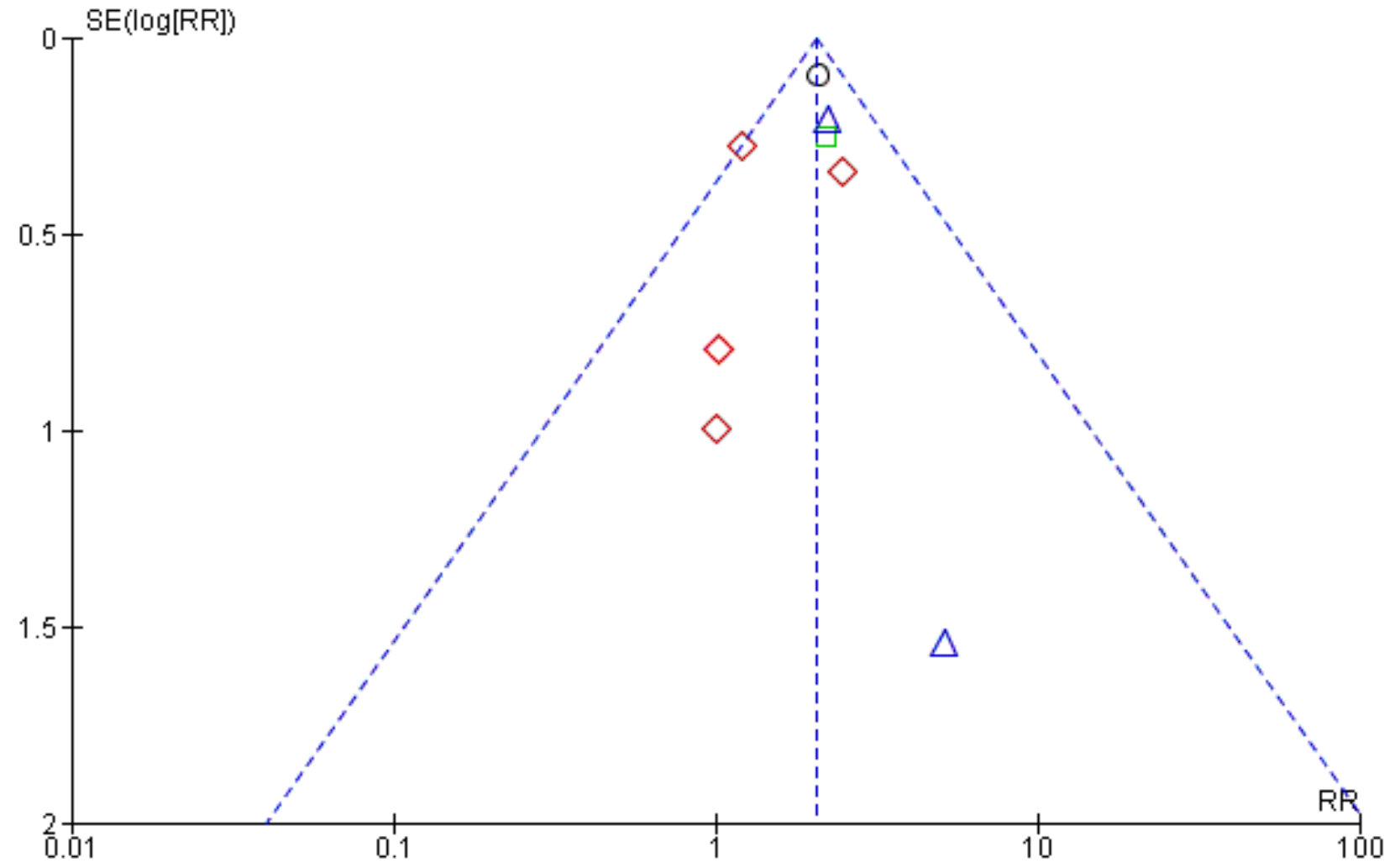

\begin{tabular}{ll} 
Subgroups & \\
\hdashline Acute coronary syndrome & $\square$ PAD \\
$\triangleright$ CABG & $\triangle$ Ischaemic stroke
\end{tabular}

\section{Heart failure}

There were insufficient data available (i.e. only one study reporting data) to perform a meta-analysis for heart failure (CURE 2001). In the CURE study, there was a mild reduction in heart failure in the clopidogrel plus aspirin group (3.7\%) compared with aspirin plus placebo (4.4\%) (CURE 2001).

\section{Subgroup analyses}

Tests for differences between subgroups indicated that there was no evidence for a difference between subgroups for any of the outcomes except all-cause mortality. For this outcome, clopidogrel appeared to have a beneficial effect on people who had had an ischaemic stroke (RR 1.45, 95\% $\mathrm{Cl} 1.10$ to 1.93; participants $=3154$; studies $=2$ but zero events in both arms of one study meant that the RR was calculated from one study only (participants $=3020$, Analysis 1.2.2). The overall analysis for this outcome found no effect, and although the test for a difference in subgroups gave moderate evidence of a difference $(P=0.02)$, this result should be viewed with caution due to the low power of this statistical test and the early stopping of the included trial due (SPS3 2012).

Subgroups where at least two studies could be pooled are discussed below.

\section{Subgroup: acute non-ST elevation coronary syndrome Cardiovascular mortality}

There was no evidence of a difference between groups in effect on cardiovascular mortality in the subgroup of participants with acute non-ST elevation coronary syndrome (RR $0.93,95 \% \mathrm{Cl} 0.80$ to 1.08 ; studies $=2$; participants $=12,648$; Analysis 1.1.1) .

\section{Subgroup: coronary artery bypass grafting}

\section{Cardiovascular mortality}

There was no evidence of a difference between groups in effect on cardiovascular mortality in the subgroup of participants undergoing coronary artery bypass grafting ( $\mathrm{RR} 0.55,95 \% \mathrm{Cl} 0.12$ to 2.57; studies $=3$, participants $=632$; Analysis 1.1.2).

\section{All-cause mortality}

There was no evidence of an effect on all-cause mortality in the subgroup of participants undergoing coronary artery bypass grafting (RR $0.37,95 \% \mathrm{Cl} 0.13$ to 1.10 ; studies $=4$, participants $=792$; Analysis 1.2.3). 


\section{Fatal and non-fatal myocardial infarction}

There was no evidence of a difference between groups in effect on fatal and non-fatal myocardial infarction in the subgroup of participants undergoing coronary artery bypass grafting (RR 0.89 , $95 \% \mathrm{Cl} 0.41$ to 1.92 ; studies $=4$; participants $=593$; Analysis 1.3.2).

\section{Fatal and non-fatal ischaemic stroke}

There was no evidence of an effect on fatal and non-fatal ischaemic stroke in the subgroup of participants undergoing coronary artery bypass grafting ( $\mathrm{RR} 0.89,95 \% \mathrm{Cl} 0.33$ to 2.40 ; studies $=2$; participants $=460$; Analysis 1.4.1).

\section{Major bleeding}

There was no evidence of a difference between groups in effect on major bleeding in the subgroup of participants undergoing coronary artery bypass grafting ( $\mathrm{RR} 1.49,95 \% \mathrm{Cl} 0.69$ to 3.19 ; studies = 4; participants = 792; Analysis 1.5.2). In addition, the small ASAPCABG 2016 study (participants $=20$ ) reported no major bleeding events in either treatment group so could not be included in the meta-analysis.

\section{Minor bleeding}

There was no evidence of a difference between groups in effect on minor bleeding in the subgroup of participants undergoing coronary artery bypass grafting ( $\mathrm{RR} 1.54,95 \% \mathrm{Cl} 1.04$ to 2.28 ; studies = 4; participants = 792; Analysis 1.6.2). In addition, the small ASAPCABG 2016 study (participants $=20$ ) reported no minor bleeding events in either treatment group so could not be included in the meta-analysis.

\section{Repeated revascularization}

There was no evidence of a difference between groups in effect on repeated revascularization in the subgroup of participants undergoing coronary artery bypass grafting (RR $0.50,95 \% \mathrm{Cl} 0.09$ to 2.72; participants $=413$; studies $=2$; Analysis 1.7) .

\section{Saphenous vein graft patency}

SVG patency was more common in the subgroup of participants taking clopidogrel plus aspirin after a coronary artery bypass graft surgery $(\mathrm{RR} 1.06,95 \% \mathrm{Cl} 1.01$ to 1.12; participants = 662; studies = 3; Analysis 1.8).

\section{Subgroup: ischaemic stroke}

\section{Fatal and non-fatal ischaemic stroke}

The risk of fatal and non-fatal stroke was lower in the subgroup of participants with previous ischaemic stroke who were taking clopidogrel plus aspirin compared with aspirin alone (RR 0.73, 95\% $\mathrm{Cl} 0.58$ to 0.91 ; studies = 3, participants = 3546; Analysis 1.4.2).

\section{Major bleeding}

Major bleeding was more common in the subgroup of participants with previous ischaemic stroke taking clopidogrel plus aspirin (RR $1.90,95 \% \mathrm{Cl} 1.39$ to 2.60 ; studies $=2$; participants $=3412$; Analysis 1.5.4). The study by Zuo 2017 had no events in either treatment group, so could not be included in this meta-analysis.

\section{Minor bleeding}

Minor bleeding was more common in the subgroup of participants with previous ischaemic stroke taking clopidogrel plus aspirin (RR $2.27,95 \% \mathrm{Cl} 1.51$ to 3.39 ; studies $=2$; participants $=526$; Analysis 1.6.4).

\section{Subgroup: peripheral arterial disease undergoing a revascularization procedure}

\section{All-cause mortality}

There was no evidence of a difference between groups in effect on all-cause mortality in the subgroup of participants undergoing a revascularization procedure for peripheral arterial disease (RR 1.34, $95 \% \mathrm{Cl} 0.74$ to 2.44; studies = 2, participants = 931; Analysis 1.2.4).

\section{Major bleeding}

There was no evidence of a difference between groups in effect on major bleeding in the subgroup of participants taking clopidogrel plus aspirin after a revascularization procedure for peripheral arterial disease (RR 1.91, $95 \% \mathrm{Cl} 0.69$ to 5.32; studies $=2$, participants $=931$; Analysis 1.5.3).

\section{Amputation}

There was no evidence of a difference between groups in effect on amputation in the subgroup of participants undergoing a revascularization procedure for peripheral arterial disease (RR 0.68, $95 \% \mathrm{Cl} 0.44$ to 1.05 ; studies = 2; participants = 931; Analysis 1.9).

\section{Sensitivity analysis}

\section{Random-effects model}

We reanalyzed data using a random-effects model instead of a fixed-effect model for all outcomes except all-cause mortality (where a random-effects model was used in the main analysis due to heterogeneity). The random-effects models were broadly similar to the fixed-effect models, and did not change interpretation of results. The sensitivity analyses are shown in Analysis 1.10; Analysis 1.11; Analysis 1.12; Analysis 1.13; Analysis 1.14; Analysis 1.15; Analysis 1.16; Analysis 1.17.

\section{Studies at low risk of bias}

Four studies were at overall low risk of bias for domains other than industry funding (CASCADE 2010; CASPAR 2010; CURE 2001; FASTER 2007). Sensitivity analysis for all main outcomes reported by at least two of these studies were broadly similar to the main results (Analysis 1.18; Analysis 1.19; Analysis 1.20; Analysis 1.21; Analysis 1.22).

\section{DISCUSSION}

\section{Summary of main results}

This systematic review of RCTs on the effect of more than 30 days' administration of clopidogrel plus low-dose aspirin compared with low-dose aspirin alone for preventing cardiovascular disease in people at high risk and in people with established cardiovascular disease without a coronary stent included 15 RCTs. We extracted data for five primary outcomes (cardiovascular mortality, all-cause mortality, fatal and non-fatal myocardial infarction, fatal and nonfatal ischaemic stroke, and adverse events) and three secondary outcomes (major bleeding, minor bleeding and heart failure). Data 
for the five primary outcomes and two secondary outcomes (major bleeding and minor bleeding) are shown in Summary of findings for the main comparison.

We found a beneficial effect of clopidogrel plus aspirin in reducing risk of myocardial infarction and ischaemic stroke, but this was also associated with an increased risk of major and minor bleeding. For other outcomes, there was no evidence for a difference between the effect of clopidogrel with aspirin compared with aspirin alone or aspirin with placebo.

\section{Overall completeness and applicability of evidence}

For a correct interpretation of these data, some comments are necessary. Several single secondary outcomes were not available in the published papers, and could not be obtained from the trial investigators. This means that the overall treatment effect may be estimated with bias as published results from particular outcomes may be correlated with the size of the effect.

The CURE study enrolled people with a recent non-ST segment elevation acute coronary syndrome and showed strong evidence of benefit for the primary outcome of fatal and non-fatal myocardial infarction. By contrast, the data from the CHARISMA 2006, PROCLAIM 2009, and Vavuranakis 2006 studies showed a benefit of clopidogrel plus aspirin compared with aspirin alone, suggesting insufficient evidence to support the use of treatment with clopidogrel plus aspirin in non-acute people at high risk of cardiovascular disease. Data from the CURE 2001 study suggested that the main benefit of clopidogrel plus aspirin therapy was in the initial period. Therefore, it is probable that clopidogrel plus aspirin was associated with an even smaller reduction in the risk of having a cardiovascular event during long-term follow-up to a mean of nine months. Given that we excluded trials with less than 30 days of treatment, a definitive conclusion on the early effects of treatment and the optimal duration of treatment were not possible. In a CURE subgroup analysis, the authors reported data between 30 days and one year after randomisation (CURE 2001). The exclusion of people who had an event in the first 30 days may have undermined the balance achieved by randomisation in the groups. For this reason, these data are potentially biased and any interpretation is difficult.

We also retrieved sufficient data to perform four predefined subgroup analyses: acute coronary syndrome without ST elevation, coronary artery bypass grafting, ischaemic stroke and peripheral arterial disease undergoing revascularization procedures. Available data on three subgroup populations (i.e. coronary artery bypass grafting, ischaemic stroke and peripheral arterial disease undergoing revascularization procedure) suggested that bleeding events were increased in each subgroup. In particular, the subanalysis on participants with ischaemic stroke suggested that clopidogrel plus aspirin increased major bleeding and minor bleeding. The only study that included post-stroke patients (SPS3 2012) reported higher all-cause mortality among people taking clopidogrel in addition to aspirin. This would indicate that this treatment option should be very carefully assessed in people who have had a stroke.

In addition, SVG patency was more common in the group of participants undergoing coronary artery bypass grafting taking clopidogrel plus aspirin.

\section{Quality of the evidence}

Offsetting the beneficial antithrombotic effect of clopidogrel is the clear increased risk of major and minor bleeding that was demonstrated during use of clopidogrel plus aspirin compared with aspirin alone (Analysis 1.5; Analysis 1.6). In addition, it should be considered that people at high risk of bleeding were excluded in all trials. For example, in the CURE study, people with contraindications to antithrombotic/antiplatelet therapy, at high risk of bleeding or ongoing long-term need for oral anticoagulants were excluded (CURE protocol).

Based on the available data, four of the 15 included studies was assessed at overall low risk of bias for domains other than industry funding (CASCADE 2010; CASPAR 2010; CURE 2001; FASTER 2007; Figure 2; Figure 3).

According to the GRADE system, quality of evidence was generally moderate for all outcomes except all-cause mortality (low quality) and adverse events (very low quality evidence) (see Summary of findings for the main comparison) (Atkins 2004).

\section{Risk of bias}

Only one outcome (fatal and non-fatal stroke) was downgraded due to concerns about a serious risk of bias. This was based on concerns over random sequence generation, blinding and allocation concealment of the studies reporting this outcome.

\section{Inconsistency}

No outcomes were downgraded for inconsistency. Although heterogeneity affected the outcome all-cause mortality $(12=40 \%)$, inspection of the forest plot showed that the two largest studies had a similar effect, and although a number of small studies had different directions of effect their Cls were extremely wide and all overlapped.

\section{Indirectness}

Only one study reported adverse events, and this had a mixed population which included people at high risk of heart disease. Therefore, results may not apply to the whole population of interest, so this outcome was downgraded for indirectness.

\section{Imprecision}

Two outcomes were downgraded for imprecision. All-cause mortality had very wide Cls that included both no effect and the possibility of appreciable benefit or harm. We downgraded adverse events for imprecision due to the low number of participants in the only study that reported this outcome.

\section{Publication bias}

Although only major bleeding had sufficient studies for a funnel plot, publication bias was strongly suspected for cardiovascular mortality, all-cause mortality, myocardial infarction, and major and minor bleeding as these important outcomes were not reported as widely as would be expected.

\section{Potential biases in the review process}

We developed search strategies, performed study selection and data collection, and assessed risk of bias for this review in 
accordance with Cochrane guidelines (Higgins 2011a; Higgins 2011b).

We conducted unplanned analyses on two subgroups of participants (see Differences between protocol and review) because all collected outcomes had a significant impact on quality of life, morbidity and mortality. For people undergoing coronary artery bypass grafting, we analysed data on the risk of repeating revascularization procedures and the rate of postoperative SVG patency. For people undergoing a revascularization procedure for peripheral arterial disease, we analysed data on the risk of amputation. The results of these unplanned analyses of additional outcomes for particular groups should be viewed with caution as they may be affected by publication bias towards positive findings, and because the decision to include them was made after seeing the results.

Several included studies were funded by the pharmaceutical companies who developed and sold clopidogrel. This is a potential limitation and, therefore, data should be interpreted with caution. Both Sanofi-Aventis and Bristol-Myers Squibb did not provide us with additional information. We obtained additional data only for the CREDO 2002, CRYSSA 2012, and ONSET/OFFSET 2010 studies. We identified one ongoing RCT that will potentially fit with our inclusion/exclusion criteria (POINT). Ongoing studies will increase the available evidence. However, it is unknown if ongoing studies will provide sufficient data to modify current evidence.

\section{Agreements and disagreements with other studies or reviews}

To the best of our knowledge, other published systematic reviews are mainly focused on specific subgroups of participants, are not specifically designed to assess the efficacy and safety of adding clopidogrel to aspirin, and are not updated (Bowry 2008; Zhang 2015).

\section{AUTHORS' CONCLUSIONS}

\section{Implications for practice}

In acute non-ST coronary syndrome, it is unclear whether the beneficial effect is largely due to the administration of the combination therapy early after the acute event combination therapy or whether the beneficial effect is consistent and relevant in the long term.

Given current data available, and until new data are published, there is no evidence of a net benefit on routinely adding clopidogrel to standard aspirin therapy for preventing cardiovascular events in people at high risk of cardiovascular disease and in people with established cardiovascular disease without a coronary stent. According to GRADE criteria, the quality of evidence was very low to moderate. In particular, use of combination therapy is associated with an increased risk of all-cause mortality, major bleeding and minor bleeding in people with a previous ischaemic stroke. In people with acute non-ST coronary syndromes, combination treatment from one to 12 months after acute event could be of benefit in people at low-risk of bleeding.

\section{Implications for research}

From a public health perspective, given the high prevalence of atherothrombosis, even a small benefit may be desirable. At this time, additional data are needed to identify a subgroup of people at very high risk of cardiovascular events and at very low risk of bleeding in which the combination of clopidogrel plus aspirin may be of clinical benefit. Before starting a new randomised controlled trial (RCT), it is advisable that reliable clinical or laboratory (or both) prognostic markers be available to select people for inclusion. Finally, forthcoming trials should uniformly present outcomes to avoid many of the problems we have experienced in being unable to get the relevant data and to permit easier systematic reviewing of the RCTs.

\section{ACK N O WLEDGEMENTS}

The authors thank Dr SR Steinhubl, Dr RF Storey and Dr VA Mannacio for providing additional information of the CREDO 2002, ONSET/OFFSET 2010, and CRYSSA 2012 study, respectively. We also thank Erica Romualdi and Tymen Keller as co-authors of the previous version of this review. 


\section{R E F E R E N C E S}

\section{References to studies included in this review}

ASAP-CABG 2016 \{published data only\}

Slim AM, Fentanes E, Thomas DM, Slim JN, Triana T, Ahmadian HR, et al. ASpirin and Plavix Following Coronary Artery Bypass Grafting (ASAP-CABG): a randomized, doubleblind, placebo-controlled pilot trial. British Journal of Medicine and Medical Research 2016; Vol. 14(3):1-10.

\section{CASCADE 2010 \{published data only\}}

* Kulik A, Le May MR, Voisine P, Tardif JC, Delarochelliere R, Naidoo S, et al. Aspirin plus clopidogrel versus aspirin alone after coronary artery bypass grafting: the clopidogrel after surgery for coronary artery disease (CASCADE) trial. Circulation 2010;122:2680-7.

Une D, Al-Atassi T, Kulik A, Voisine P, Le May M, Ruel M. Impact of clopidogrel plus aspirin versus aspirin alone on the progression of native coronary artery disease after bypass surgery: analysis from the Clopidogrel After Surgery for Coronary Artery DiseasE (CASCADE) randomized trial. Circulation 2014;130 (suppl 1):S12-8.

Une D, Kulik A, Voisine P, Le May M, Ruel M. Correlates of saphenous vein graft hyperplasia and occlusion 1 year after coronary artery bypass grafting: analysis from the CASCADE randomized trial. Circulation 2013;128 (suppl 1):S213-8.

\section{CASPAR 2010 \{published data only\}}

Belch JJ, Dormandy J, Biasi GM, Cairols M, Diehm C, Eikelboom B, et al. Results of the randomized, placebocontrolled clopidogrel and acetylsalicylic acid in bypass surgery for peripheral arterial disease (CASPAR) trial. Journal of Vascular Surgery 2010;52:825-33.

\section{CHARISMA 2006 \{published data only\}}

Berger JS, Bhatt DL, Steg PG, Steinhubl SR, Montalescot G, Shao M, et al. Bleeding, mortality, and antiplatelet therapy: results from the Clopidogrel for High Atherothrombotic Risk and Ischemic Stabilization, Management, and Avoidance (CHARISMA) trial. American Heart Journal 2011;162:98-105.

Berger PB, Bhatt DL, Fuster V, Steg PG, Fox KA, Shao M, et al. Bleeding complications with dual antiplatelet therapy among patients with stable vascular disease or risk factors for vascular disease: results from the Clopidogrel for High Atherothrombotic Risk and Ischemic Stabilization, Management, and Avoidance (CHARISMA) trial. Circulation 2010;121:2575-83.

* Bhatt DL, Fox KA, Hacke W, Berger PB, Black HR, Boden WE, et al. Clopidogrel and aspirin versus aspirin alone for the prevention of atherothrombotic events. New England Journal of Medicine 2006;354:1706-17.

Hankey GJ, Johnston SC, Easton JD, Hacke W, Mas JL, Brennan D, et al. Effect of clopidogrel plus ASA vs. ASA early after TIA and ischaemic stroke: a substudy of the CHARISMA trial. International Journal of Stroke 2011;6:3-9.

Steinhubl SR, Bhatt DL, Brennen DM, Montalescot G, Hankey GJ, Eikelboom JW, et al. Aspirin prevent cardiovascular disease: the association aspirin dose and clopidogrel with thrombosis and bleeding. Annals of Internal Medicine 2009;150:379-86.

\section{CRYSSA 2012 \{published data only\}}

Mannacio VA, Di Tommaso L, Antignan A, De Amicis V, Vosa C. Aspirin plus clopidogrel for optimal platelet inhibition following off-pump coronary artery bypass surgery: results from the CRYSSA (prevention of Coronary arteRY bypaSS occlusion After off-pump procedures) randomised study. Heart 2012;98:1710-5.

\section{CURE 2001 \{published data only\}}

Anand SS, Xie CC, Mehta S, Franzosi MG, Joyner C, Chrolavicius S, et al. Differences in the management and prognosis of women and men who suffer from acute coronary syndromes. Journal of the American College of Cardiology 2005;46:1845-51.

Budaj A, Yusuf S, Mehta SR, Fox KA, Tognoni G, Zhao F, et al. Benefit of clopidogrel in patients with acute coronary syndromes without ST-segment elevation in various risk groups. Circulation 2002;106(13):1622-6.

Fox KA, Mehta SR, Peters R, Zhao F, Lakkis N, Gersh BJ, et al. Benefits and risks of the combination of clopidogrel and aspirin in patients undergoing surgical revascularization for non-STelevation acute coronary syndrome: the Clopidogrel in Unstable angina to prevent Recurrent ischemic Events (CURE) Trial. Circulation 2004;110(10):1202-8.

Lewis BS, Mehta SR, Fox KAA, Halon DA, Zhao F, Peters RJG, et al. Benefit of clopidogrel according to timing of percutaneous coronary intervention in patients with acute coronary syndromes: further results from the Clopidogrel in Unstable angina to prevent Recurrent Events (CURE) study. American Heart Journal 2005;150:1177-84.

Mahoney EM, Mehta S, Yuan Y, Jackson J, Chen R, Gabriel S, et al. Long-term cost-effectiveness of early and sustained clopidogrel therapy for up to 1 year in patients undergoing percutaneous coronary intervention after presenting with acute coronary syndromes without ST-segment elevation. American Heart Journal 2006;151:219-27.

Mehta SR, Yusuf S, Peters RJ, Bertrand ME, Lewis BS, Natarajan MK, et al. Effects of pretreatment with clopidogrel and aspirin followed by long-term therapy in patients undergoing percutaneous coronary intervention: the $\mathrm{PCI}-\mathrm{CURE}$ study. Lancet 2001;358:527-33.

Peters RJG, Mehta SR, Fox KAA, Zhao F, Lewis BS, Kopecky SL, et al. Effects of aspirin dose when used alone or in combination with clopidogrel in patients with acute coronary syndromes: observations from the Clopidogrel in Unstable angina to prevent Recurrent Events (CURE) study. Circulation 2003;108(14):1682-7.

Yusuf S, Mehta SR, Zhao F, Gersh BJ, Commerford PJ, Blumenthal M, et al. Early and late effects of clopidogrel in patients with acute coronary syndromes. Circulation 2003;107(7):966-72. 
* Yusuf S, Zhao F, Mehta SR, Chrolavicius S, Tognoni G, Fox KK. Effects of clopidogrel in addition to aspirin in patients with acute coronary syndromes without ST-segment elevation. New England Journal of Medicine 2001;345:494-502.

\section{FASTER 2007 \{published data only\}}

Kennedy J, Hill MD, Ryckborst KJ, Eliasziw M, Demchuk, Buchan AM. Fast assessment of stroke and transient ischemic attack to prevent early recurrence (FASTER): a randomised controlled pilot trial. Lancet Neurology 2007;6:961-9.

\section{Gao 2010 \{published data only\}}

Gao G, Zheng Z, Pi Y, Lu B, Lu J, Hu S. Aspirin plus clopidogrel therapy increases early venous graft patency after coronary artery bypass surgery: a single-center, randomized, controlled trial. Journal of the American College of Cardiology 2010;56:1639-43.

\section{Gasparovic 2014 \{published data only\}}

Gasparovic H, Petricevic M, Kopjar T, Djuric Z, Svetina L, Biocina B. Impact of dual antiplatelet therapy on outcomes among aspirin-resistant patients following coronary artery bypass grafting. American Journal of Cardiology 2014;113:1660-7.

\section{MIRROR 2012 \{published data only\}}

Strobl FF, Brechtel K, Schmehl J, Zeller T, Reiser MF, Claussen CD, et al. Twelve-month results of a randomized trial comparing mono with dual antiplatelet therapy in endovascularly treated patients with peripheral artery disease. Journal of Endovascular Therapy 2013;20:699-706.

* Tepe G, Bantleon R, Brechtel K, Schmehl J, Zeller T, Claussen $C D$, et al. Management of peripheral arterial interventions with mono or dual antiplatelet therapy - the MIRROR study: a randomised and double-blinded clinical trial. European Journal of Radiology 2012;22:1998-2006.

\section{PROCLAIM 2009 \{published data only\}}

Willerson JT, Cable G, Yeh ET, PROCLAIM Investigators. PROCLAIM: pilot study to examine the effects of clopidogrel on inflammatory markers in patients with metabolic syndrome receiving low-dose aspirin. Texas Heart Institute Journal 2009;36:530-9.

\section{SPS3 2012 \{published data only\}}

Benavente OR, Hart RG, McClure LA, Szychowski JM, Coffey CS, Pearce LA. Effects of clopidogrel added to aspirin in patients with recent lacunar stroke. New England Journal of Medicine 2012;367:817-25.

\section{TEG-CABG \{published data only\}}

Rafiq S, Johansson PI, Kofoed KF, Lund JT, Olsen PS, Bentsen S, et al. Thrombelastographic hypercoagulability and antiplatelet therapy after coronary artery bypass surgery (TEG-CABG trial): a randomized controlled trial. Platelets 2017; Vol. 22:1-8.

\section{Vavuranakis 2006 \{published data only\}}

Vavuranakis M, Latsios G, Aggelis D, Bosinakou I, Karambelas I, Tousoulis D, et al. Randomized comparison of the effects of ASA plus clopidogrel versus ASA alone on early platelet activation in acute coronary syndromes with elevated high-sensitivity C-reactive protein and soluble CD40 ligand levels. Clinical Therapeutics 2006;28:860-71.

\section{Zuo 2017 \{published data only\}}

Zuo FT, Liu H, Wu HJ, Su N, Liu JQ, Dong AQ. The effectiveness and safety of dual antiplatelet therapy in ischemic cerebrovascular disease with intracranial and extracranial arteriostenosis in Chinese patients. Medicine 2017;96(1):e5497.

\section{References to studies excluded from this review}

\section{Akbulut 2004 \{published data only\}}

Akbulut M, Ozbay Z, Karaca I, Ilkay E, Gundogdu O, Arslan N. The effect of long-term clopidogrel use on neointimal formation after percutaneous coronary intervention. Coronary Artery Disease 2004;15:347-52.

\section{ARTE \{published data only\}}

NCT01559298. Aspirin versus aspirin + clopidogrel following transcatheter aortic valve implantation: the ARTE trial. clinicaltrials.gov/ct2/show/NCT01559298 Date first received: 21 March 2012

\section{Azar 2006 \{published data only\}}

Azar RR, Kassab R, Zoghbi A, Aboujaoudé S, El-Osta H, Ghorra P, et al. Effects of clopidogrel on soluble CD40 ligand and on highsensitivity C-reactive protein in patients with stable coronary artery disease. American Heart Journal 2006;151:521.e1-e4.

\section{Azcona 2012 \{published data only\}}

Azcona L, Lopez Farre' AJ, Jimenez Mateos-Caceres P, Segura A, Rodriguez P, Modrego J, et al. Impact of clopidogrel and aspirin treatment on the expression of proteins in platelets from type-2 diabetic patients with stable coronary ischemia. Journal of Pharmaceutical Sciences 2012;101:2821-32.

\section{Bernardi 2007 \{published data only\}}

Bernardi V, Szarfer J, Summay G, Mendiz O, Sarmiento R, Alemparte MR,', et al. Long-term versus short-term clopidogrel therapy in patients undergoing coronary stenting (from the Randomized Argentine Clopidogrel Stent [RACS] Trial). American Journal of Cardiology 2007;99:349-52.

\section{CARESS 2005 \{published data only\}}

Dittrich R, Ritter MA, Kaps M, Siebler M, Lees K, Larrue V, et al. The use of embolic signal detection in multicenter trials to evaluate antiplatelet efficacy signal analysis and quality control mechanisms in the CARESS (clopidogrel and aspirin reduction emboli symptomatic carotid stenosis). Stroke 2006;37:1065-9.

* Markus HS, Droste DW, Kaps M, Larrue V, Lees KR, Siebler M, et al. Dual antiplatelet therapy with clopidogrel and aspirin in symptomatic carotid stenosis evaluated using doppler embolic signal detection. The clopidogrel and aspirin for reduction of emboli in symptomatic carotid stenosis (CARESS) trial. Circulation 2005;111:2233-40.

\section{Cassar 2005 \{published data only\}}

Cassar K, Ford I, Greaves M, Bachoo P, Brittenden J. Randomized clinical trial of the antiplatelet effects of aspirin-clopidogrel 
combination versus aspirin alone after low limb angioplasty. British Journal of Surgery 2005;92:159-65.

\section{CHANCE 2013 \{published data only\}}

Li Z, Wang Y, Zhao X, Liu L, Wang D, Wang C, et al. Treatment effect of clopidogrel plus aspirin within 12 hours of acute minor stroke or transient ischemic attack. JAMA 2016;5(3):e003038.

Liu L, Wong KS, Leng X, Pu Y, Wang Y, Jing J, et al. Dual antiplatelet therapy in stroke and ICAS. Subgroup analysis of CHANCE. Neurology 2015;85:1154-62.

Pan Y, Jing J, Chen W, Meng X, Li H, Zhao X, et al. Risks and benefits of clopidogrel-aspirin in minor stroke or TIA: time course analysis of CHANCE. Neurology 2017;88(20):1906-11.

Wang X, Zhao X, Johnston SC, Xian Y, Hu B, Wang C, et al. Effect of clopidogrel with aspirin on functional outcome in TIA or minor stroke: CHANCE substudy. Neurology 2015;85:573-9.

Wang Y, Pan Y, Zhao X, Li H, Wang D, Johnston SC, et al. Clopidogrel with aspirin in acute minor stroke or transient ischemic attack (CHANCE) trial. One-year outcomes. Circulation 2015;132:40-6.

Wang Y, Wang Y, Zhao X, Liu L, Wang D, Wang C, et al. Clopidogrel with aspirin in acute minor stroke or transient ischemic attack. New England Journal of Medicine 2013;368:11-9.

Wang Z, Xu C, Wang P, Wang Y, Xin H. Combined clopidogrelaspirin treatment for high risk TIA or minor stroke does not increase cerebral microbleeds. Neurological Research 2015;37(11):993-7.

\section{CLAIR 2010 \{published data only\}}

Deng QQ, Tang J, Chen C, Markus H, Huang YN, Zhao H, et al. The curative effect comparison of two kinds of therapeutic regimens on decreasing the relative intensity of microembolic signal in CLAIR trial. Journal of the Neurological Sciences 2016;367:18-21.

Lau AY, Zhao Y, Chen C, Leung TW, Fu J, Huang Y, et al. Dual antiplatelets reduce microembolic signals in patients with transient ischemic attack and minor stroke: subgroup analysis of CLAIR study. International Journal of Stroke 2014;Suppl A100:127-32.

Wang X, Lin WH, Zhao YD, Chen XY, Leung TW, Chen C, et al. The effectiveness of dual antiplatelet treatment in acute ischemic stroke patients with intracranial arterial stenosis: a subgroup analysis of CLAIR study. International Journal of Stroke 2013;8:663-8.

Wong KS, Chen C, Fu J, Chang HM, Suwanwela NC, Huang YN, et al. Clopidogrel plus aspirin versus aspirin alone for reducing embolisation in patients with acute symptomatic cerebral or carotid artery stenosis (CLAIR study): a randomised, open-label, blinded-endpoint trial. Lancet Neurology 2010;9(5):489-97.

\section{CLARITY-TIMI 282005 \{published data only\}}

Sabatine MS, Cannon CP, Gibson CM, Lopez-Sendon JL, Montalescot G, Theroux P, et al. Addition of clopidogrel to aspirin and fibrinolytic therapy for myocardial infarction with ST-segment elevation. New England Journal of Medicine 2005;352:1179-89.

\section{COMMIT 2005 \{published data only\}}

COMMIT (ClOpidogrel and Metoprolol in Myocardial Infarction Trial) collaborative group. Addition of clopidogrel to aspirin in 45852 patients with acute myocardial infarction: randomised placebo-controlled trial. Lancet 2005;366:1607-21.

\section{CREDO 2002 \{published data only\}}

Kelly RV, Hsu A, Topol E, Steinhubl S. The influence of body mass index on outcomes and the benefit of antiplatelet therapy following percutaneous coronary intervention. Journal of Invasive Cardiology 2006;18:115-9.

Mukherjee D, Topol EJ, Moliterno DJ, Brennan DM, Ziada K, Cho $L$, et al. Extracardiac vascular disease and effectiveness of sustained clopidogrel treatment. Heart 2006;92:49-51.

Saw J, Topol EJ, Steinhubl SR, Brennan D, Berger PB, Moliterno DJ, et al. Comparison of long-term usefulness of clopidogrel therapy after the first percutaneous coronary intervention or coronary artery bypass grafting versus that after the second or repeat intervention. American Journal of Cardiology 2004;94:623.

* Steinhubl SR, Berger PB, Mann JTIII, Fry ET, DeLago A, Wilmer $\mathrm{C}$, et al. Early and sustained dual oral antiplatelet therapy following percutaneous coronary intervention: a randomized controlled trial. JAMA 2002;288:2411-20.

\section{Eriksson 2009 \{published data only\}}

Eriksson AC, Jonasson L, Lindahl TL, Hedbäck B, Whiss PA. Static platelet adhesion, flow cytometry and serum TXB2 levels for monitoring platelet inhibiting treatment with ASA and clopidogrel in coronary artery disease: a randomised cross-over study. Journal of Translational Medicine 2009;7:42.

\section{EXCELLENT 2012 \{published data only\}}

Gwon HC, Hahn JY, Park KW, Song YB, Chae IH, Lim DS, et al. Six-month versus 12-month dual antiplatelet therapy after implantation of drug-eluting stents: the Efficacy of Xience/ Promus Versus Cypher to Reduce Late Loss After Stenting (EXCELLENT) randomised, multicenter study. Circulation 2012;125:505-13.

\section{Geraghty 2010 \{published data only\}}

Geraghty OC, Kennedy J, Chandratheva A, Marquardt L, Buchan AM, Rothwell PM. Preliminary evidence of a high risk of bleeding on aspirin plus clopidogrel in aspirin-naïve patients in the acute phase after TIA or minor ischaemic stroke. Cerebrovascular Disorders 2010;29:460-7.

\section{Hong 2016 \{published data only\}}

Hong KS, Lee SH, Kim EG, Cho KH, Chang DI, Rha JH, et al. Recurrent ischemic lesions after acute atherothrombotic stroke: clopidogrel plus aspirin versus aspirin alone. Stoke 2016;47(9):2323-30. 


\section{Hui 2016 \{published data only\}}

Hui Y. The clinical efficacy research for the treatment among intravenous unfractionated heparin, two antiplatelet agents (clopidogrel and aspirin) and single antiplatelet agent (aspirin) to acute cerebral infarction and transient ischemic attack (TIA). www.chictr.org.cn/showprojen.aspx?proj=11770 Date first registered: 16 February 2016.

\section{Jagroop 2004 \{published data only\}}

Jagroop IA, Matsagas MI, Geroulakos G, Mikhailidis DP. The effect of clopidogrel, aspirin and both antiplatelet drugs on platelet function in patients with peripheral arterial disease. Platelets 2004;15:117-25.

\section{Kayacioglu 2008 \{published data only\}}

Kayacioglu I, Gunay R, Saskin H, Idiz M, Sensoz Y, Ates M, et al. The role of clopidogrel and acetylsalicylic acid in the prevention of early-phase graft occlusion due to reactive thrombocytosis after coronary artery bypass operation. Heart Surgery Forum 2008;11:E152-7.

\section{MATCH 2004 \{published data only\}}

Diener HC, Bogousslavsky J, Brass LM, Cimminiello C, Csiba L, Kaste M, et al. Aspirin and clopidogrel compared with clopidogrel alone after recent ischaemic stroke or transient ischaemic attack in high-risk patients (MATCH): randomised, double-blind, placebo-controlled trial. Lancet 2004;364:331-7.

\section{Mujanovic 2009 \{published data only\}}

Mujanovic E, Nurkic M, Caluk J, Terzic I, Kabil E, Bergsland J. The effect of combined clopidogrel and aspirin therapy after offpump coronary surgery. A pilot study. Innovations 2009;4:265-8.

\section{ONSET/OFFSET 2010 \{published data only\}}

Storey RF, Bliden KP, Patil SB, Karunakaran A, Ecob R, Butler K, et al. Incidence of dyspnea and assessment of cardiac and pulmonary function in patients with stable coronary artery disease receiving ticagrelor, clopidogrel, or placebo in the ONSET/OFFSET study. Journal of the American College of Cardiology 2010;56:185-93.

\section{Pal 2016 \{published data only\}}

Pal M, Prasad O, Fatima A, Bakki C, Ahmed M. Assessment of secondary recurrence of stroke in aspirin-clopidogrel combination therapy and aspirin monotherapy in transient ischemic attack patients in South India: a comparative study. Value in Health 2016;19(7):A863.

\section{Pekdemir 2003 \{published data only\}}

Pekdemir H, Cin VG, Camsari A, Cicek D, Akkus NM, Doven O, et al. A comparison of 1-month and 6-month clopidogrel therapy on clinical and angiographic outcome after stent implantation. Heart and Vessels 2003;18(3):123-9.

\section{PRODIGY 2012 \{published data only\}}

Valgimigli M, Campo G, Monti M, Vranckx P, Percoco G, Tumscitz C, et al. Short- versus long-term duration of dualantiplatelet therapy after coronary stenting. Circulation 2012;125:2015-26.

\section{REAL-LATE/ZEST-LATE 2010 \{published data only\}}

Park SJ, Park DW, Kim YH, Kang SJ, Lee SW, Lee CW, et al. Duration of dual antiplatelet therapy after implantation of drug-eluting stents. New England Journal of Medicine 2010;362:1374-82.

\section{RESET 2012 \{published data only\}}

Kim BK, Hong MK, Shin DH, Nam CM, Kim JS, Ko YG, et al. A new strategy for discontinuation of dual antiplatelet therapy. Journal of the American College of Cardiology 2012;60:1340-8

\section{Steinhubl 2006 \{published data only\}}

SteinhubI SR, Berger PB, Brennan DM, Topol EJ, for the CREDO Investigators. Optimal timing for the initiation of pre-treatment with 300 mg clopidogrel before percutaneous coronary intervention. Journal of the American College of Cardiology 2006;47:939-43.

\section{Suh 2011 \{published data only\}}

Suh JW, Seung KB, Kwak CH, Kim KS, Hong SJ, Park TH, et al. Comparison of antiplatelet effect and tolerability of clopidogrel resinate with clopidogrel bisulfate in patients with coronary heart disease (CHD) or CHD-equivalent risks: a phase IV, prospective, double-dummy, parallel-group, 4-week noninferiority trial. Clinical Therapeutics 2011;33:1057-68.

\section{Thopte 2014 \{published data only\}}

Thopte OS, Patil SP, Deshmukh RS. A study of aspirin plus clopidogrel versus aspirin alone on saphenous vein graft patency after coronary artery bypass graft surgery - an angiographic follow-up after three months. Indian Heart Journal 2014;66:S22.

\section{Undas 2009 \{published data only\}}

Undas A, Stepień E, Branicka A, Wołkow P, Zmudka K, Tracz W. Thrombin formation and platelet activation at the site of vascular injury in patients with coronary artery disease treated with clopidogrel combined with aspirin. Kardiologia Polska (Polish Heart Journal) 2009;67(6):591-8.

\section{Ussia 2011 \{published data only\}}

Ussia GP, Scarabelli M, Mulè M, Barbanti M, Sarkar K, Cammalleri V, et al. Dual antiplatelet therapy versus aspirin alone in patients undergoing transcatheter aortic valve implantation. American Journal of Cardiology 2011;108(12):1772-6.

\section{Wang 2015 \{published data only\}}

Wang C, Yi X, Zhang B, Liao D, Lin J, Chi L. Clopidogrel plus aspirin prevents early neurologic deterioration and improves 6-Month outcome in patients with acute large artery atherosclerosis stroke. Clinical and Applied Thrombosis/ hemostasis 2015;21(5):453-461.

\section{Willoughby 2014 \{published data only\}}

Willoughby SR, Luu L, Cameron JD, Nelson AJ, Schultz CD, Worthley SG, et al. Clopidogrel improves microvascular endothelial function in subjects with stable coronary artery disease. Heart, Lung and Circulation 2014;23:534-41. 
Wilson 2009 \{published data only\}

Wilson AM, Brittenden J, Bachoo P, Ford I, Nixon GF. Randomized controlled trial of aspirin and clopidogrel versus aspirin and placebo on markers of smooth muscle proliferation before and after peripheral angioplasty. Journal of Vascular Surgery 2009;50(4):861-9.

\section{Xydakis 2004 \{published data only\}}

Xydakis D, Papadogiannakis A, Sfakianaki M, Vakouti E, Papachristoforou K. The combination of clopidogrel and acetylsalicylic acid inhibits more effective the platelet activation in haemodialysis patients with acute coronary syndromes and high $\mathrm{C}$ reactive protein. 41st Congress of the European Renal Association. European Dialysis and Transplantation Association; 2004 May 15-18; Lisbon, Portugal. 2004.

\section{Yi 2014 \{published data only\}}

Yi X, Lin J, Wang C, Zhang B, Chi W. A comparative study of dual versus mono-antiplatelet therapy in patients with acute large-artery atherosclerosis stroke. Journal of Stroke and Cerebrovascular Diseases 2014;23:1975-81.

\section{Zhao 2003 \{published data only\}}

Zhao L, Fletcher S, Weaver C, Leonardi-Bee J, May J, Fox S, et al. The effects of three anti-platelet drugs (aspirin, clopidogrel, dipyridamole) given singly or together on platelet and leucocyte function in healthy subjects and patients with previous ischemic stroke. Journal of Thrombosis \& Haemostasis 2003;1(Suppl 1):P1010.

\section{References to ongoing studies}

POINT \{published data only\}

NCT00991029. Platelet-oriented inhibition in new TIA and minor ischemic stroke (POINT) trial: rationale and design. clinicaltrials.gov/ct2/show/NCT00991029 Date first received: 7 October 2009.

\section{Additional references}

\section{ACCP 2012}

Eikelboom JW, Hirsh J, Spencer FA, Baglin TP, Weitz JI. Antiplatelet drugs. Antithrombotic therapy and prevention of thrombosis, 9th ed: American College of Chest Physicians evidence-based clinical practice guidelines. Chest 2012;141(2):e89S-119S.

\section{AHA Statistical Update 2017}

Benjamin EJ, Blaha MJ, Chiuve SE, Cushman M, Das SR, Deo R, et al. American Heart Association Statistics Committee and Stroke Statistics Subcommittee. Heart disease and stroke statistics - 2017 update: a report from the American Heart Association. Circulation 2017;135:e146-603.

\section{ATC 2009}

Antithrombotic Trialists' (ATT) Collaboration. Aspirin in the primary and secondary prevention of vascular disease: collaborative meta-analysis of individual participant data from randomised trials. Lancet 2009;373:1849-60.

\section{Atkins 2004}

Atkins D, Best D, Briss PA, Eccles M, Falck-Ytter Y, Flottorp S, et al. GRADE Working Group. Grading quality of evidence and strength of recommendations. BMJ 2004;328:1490-4.

\section{BARC 2011}

Mehran R, Rao SV, Bhatt DL, Gibson CM, Caixeta A, Eikelboom J, et al. Standardized bleeding definitions for cardiovascular clinical trials: a consensus report from the Bleeding Academic Research Consortium. Circulation 2011;123:2736e2747.

\section{Bedenis 2014}

Bedenis R, Stewart M, Cleanthis M, Robless P, Mikhailidis DP, Stansby G. Cilostazol for intermittent claudication. Cochrane Database of Systematic Reviews 2014, Issue 10. [DOI: 10.1002/14651858.CD003748.pub4]

\section{Bedenis 2015}

Bedenis R, Lethaby A, Maxwell H, Acosta S, Prins MH. Antiplatelet agents for preventing thrombosis after peripheral arterial bypass surgery. Cochrane Database of Systematic Reviews 2015, Issue 2. [DOI: 10.1002/14651858.CD000535.pub3]

\section{Bowry 2008}

Bowry AD, Brookhart MA, Choudhry NK. Meta-analysis of the efficacy and safety of clopidogrel plus aspirin as compared to antiplatelet monotherapy for the prevention of vascular events. American Journal of Cardiology 2008;101:960-6.

\section{CAPRIE 1996}

CAPRIE Steering Committee. A randomised, blinded, trial of clopidogrel versus aspirin in patients at risk of ischaemic events (CAPRIE). Lancet 1996;348:1329-39.

\section{Cosmi 2001}

Cosmi B, Rubboli A, Castelvetri C, Milandri M. Ticlopidine versus oral anticoagulation for coronary stenting. Cochrane Database of Systematic Reviews 2001, Issue 4. [DOI: 10.1002/14651858.CD002133]

\section{CURE protocol}

CURE Study Investigators. The Clopidogrel in Unstable angina to prevent Recurrent Events (CURE) trial programme: rationale, design and baseline characteristics including a meta-analysis of the effects of thienopyridines in vascular disease. European Heart Journal 2000;21:2033-41.

\section{Deeks 2011}

Deeks JJ, Higgins JPT, Altman DG. Chapter 9: Analysing data and undertaking meta-analyses. In: Higgins JP, Green S, editor(s). Cochrane Handbook for Systematic Reviews of Interventions Version 5.1.0 (updated March 2011). The Cochrane Collaboration, 2011. Available from handbook.cochrane.org.

\section{Dorffler-Melly 2003a}

Dorffler-Melly J, Buller HR, Koopman MM, Prins MH. Antiplatelet agents for preventing thrombosis after peripheral arterial bypass surgery. Cochrane Database of Systematic Reviews 2003, Issue 3. [DOI: 10.1002/14651858.CD000535] 


\section{Dorffler-Melly 2003b}

Dorffler-Melly J, Buller HR, Koopman MM, Prins MH. Antithrombotic agents for preventing thrombosis after infrainguinal arterial bypass surgery. Cochrane Database of Systematic Reviews 2003, Issue 2. [DOI: 10.1002/14651858.CD000536]

\section{Dorffler-Melly 2005}

Dorffler-Melly J, Koopman MMW, Prins MH, Buller HR. Antiplatelet and anticoagulant drugs for prevention of restenosis/reocclusion following peripheral endovascular treatment. Cochrane Database of Systematic Reviews 2005, Issue 1. [DOI: 10.1002/14651858.CD002071.pub2]

\section{Egger 1997}

Egger M, Smith GD, Schneider M, Minder C. Bias in meta-analysis detected by a simple, graphical test. BMJ 1997;315:629-34.

\section{European Heart Network 2017}

Wilkins E, Wilson L, Wickramasinghe K, Bhatnagar P, Leal J, Luengo-Fernandez R, et al. European Cardiovascular Disease Statistics 2017. Brussels (Belgium): European Heart Network, 2017.

\section{Gaspoz 2002}

Gaspoz JM, Coxson PG, Goldman PA, Williams LW, Kuntz KM, Hunink MGM, et al. Cost effectiveness of aspirin, clopidogrel, or both for secondary prevention of coronary heart disease. New England Journal of Medicine 2002;346:1800-6.

\section{Geraghty 2011}

Geraghty AJ, Welch K. Antithrombotic agents for preventing thrombosis after infrainguinal arterial bypass surgery. Cochrane Database of Systematic Reviews 2011, Issue 6. [DOI: 10.1002/14651858.CD000536.pub2]

\section{GUSTO 1993}

The GUSTO Investigators. An international randomized trial comparing four thrombolytic strategies for acute myocardial infarction. New England Journal of Medicine 1993;329:673-82.

\section{Hankey 2004}

Hankey GJ, Sudlow CLM, Dunbabin DW. Thienopyridine derivatives (ticlopidine, clopidogrel) versus aspirin for preventing stroke and other serious vascular events in high vascular risk patients. Cochrane Database of Systematic Reviews 2004, Issue 2. [DOI: 10.1002/14651858.CD001246]

\section{Higgins 2011a}

Higgins JPT, Deeks JJ. Chapter 7: Selecting studies and collecting data. In: Higgins JP, Green S, editor(s). Cochrane Handbook for Systematic Reviews of Interventions Version 5.1.0 (updated March 2011). The Cochrane Collaboration, 2011. Available from handbook.cochrane.org.

\section{Higgins 2011b}

Higgins JPT, Altman DG. Chapter 8: Assessing risk of bias in included studies. In: Higgins JP, Green S, editor(s). Cochrane Handbook for Systematic Reviews of Interventions Version 5.1.0 (updated March 2011). The Cochrane Collaboration, 2011. Available from handbook.cochrane.org.

\section{Lefebvre 2011}

Lefebvre C, Manheimer E, Glanville J. Chapter 6: Searching for studies. In: Higgins JP, Green S, editor(s). Cochrane Handbook for Systematic Reviews of Interventions Version 5.1.0 (updated March 2011). The Cochrane Collaboration, 2011. Available from handbook.cochrane.org.

\section{Main 2004}

Main C, Palmer S, Griffin S, Jones L, Orton V, Sculpher M. Clopidogrel used in combination with aspirin compared with aspirin alone in the treatment of non-ST-segment-elevation acute coronary syndromes: a systematic review and economic evaluation. Health Technology Assessment 2004;40:1-56.

\section{Morant 2003}

Morant SV, McMahon AD, Cleland JGF, Davey PG, MacDonald TM. Cardiovascular prophylaxis with aspirin: costs of supply and management of upper gastrointestinal and renal toxicity. British Journal of Clinical Pharmacology 2003;57:188-98.

\section{NICE 2004}

Main C, Palmer S, Griffin S, Jones L, Orton V, Sculpher M, et al. A rapid and systematic review on clinical effectiveness and costeffectiveness of clopidogrel used in combination with aspirin compared to aspirin alone in the treatment of non-ST-segmentelevation acute coronary syndromes (ACS) (assessment report). www.nice.org.uk/guidance/ta80/documents/acute-coronarysyndromes-clopidogrel-assessment-report2 (accessed prior to 28 November 2017).

\section{Patrono 2011}

Patrono C, Andreotti F, Arnesen H, Badimon L, Baigent C, Collet JP, et al. Antiplatelet agents for the treatment and prevention of atherothrombosis. European Heart Journal 2011;32:2922-32.

\section{PRISMA}

Moher D, Liberati A, Tetzlaff J, Altman DG, PRISMA Group. Preferred reporting items for systematic reviews and meta-analyses: the PRISMA statement. Journal of Clinical Epidemiology 2009;62:1006-12.

\section{RevMan 2014 [Computer program]}

The Nordic Cochrane Centre, The Cochrane Collaboration. Review Manager (RevMan). Version 5.3. Copenhagen: The Nordic Cochrane Centre, The Cochrane Collaboration, 2014.

\section{Robertson 2012}

Robertson L, Ghouri MA, Kovacs F. Antiplatelet and anticoagulant drugs for prevention of restenosis/reocclusion following peripheral endovascular treatment. Cochrane Database of Systematic Reviews 2012, Issue 8. [DOI: 10.1002/14651858.CD002071.pub3]

\section{Robless 2003}

Robless P, Mikhailidis D, Stansby G. Cilostazol for peripheral arterial disease. Cochrane Database of Systematic Reviews 2003, Issue 4. [DOI: 10.1002/14651858.CD001272] 


\section{Robless 2007}

Robless P, Mikhailidis D, Stansby GP. Antiplatelet agents for intermittent claudication. Cochrane Database of Systematic Reviews 2007, Issue 1. [DOI: 10.1002/14651858.CD003748.pub2]

\section{Sudlow 2009}

Sudlow CL, Mason G, Maurice JB, Wedderburn CJ, Hankey GJ. Thienopyridine derivatives versus aspirin for preventing stroke and other serious vascular events in high vascular risk patients. Cochrane Database of Systematic Reviews 2009, Issue 4. [DOI: 10.1002/14651858.CD001246.pub2]

\section{Valentine 2012}

Valentine N, van de Laar FA, van Driel ML. Adenosinediphosphate (ADP) receptor antagonists for the prevention of cardiovascular disease in type 2 diabetes mellitus. Cochrane Database of Systematic Reviews 2012, Issue 11. [DOI: 10.1002/14651858.CD005449.pub2]

\section{WHO 2016}

World Health Organization. Global Health Estimates 2015: Deaths by Cause, Age, Sex, by Country and by Region, 2000-2015. World Health Reports. Geneva (Switzerland): World Health Organization, 2016.

\section{Wong 2011}

Wong PF, Chong LY, Mikhailidis DP, Robless P, Stansby G. Antiplatelet agents for intermittent claudication. Cochrane
Database of Systematic Reviews 2011, Issue 11. [DOI: 10.1002/14651858.CD001272.pub2]

\section{Zakarija 2004}

Zakarija A, Bandarenko N, Pandey DK, Auerbach A, Raisch DW, Kim B, et al. Clopidogrel-associated TTP: an update of pharmacovigilance efforts conducted by independent researchers, pharmaceutical suppliers, and the Food and Drug Administration. Stroke 2004;35:533-7.

\section{Zhang 2015}

Zhang Q, Wang C, Zheng M, Li Y, Li J, Zhang L, et al. Aspirin plus clopidogrel as secondary prevention after stroke or transient ischemic attack: a systematic review and meta-analysis. Cerebrovascular Diseases (Basel, Switzerland) 2015;39:13-22.

\section{References to other published versions of this review Squizzato 2011}

Squizzato A, Keller T, Romualdi E, Middeldorp S. Clopidogrel plus aspirin versus aspirin alone for preventing cardiovascular disease. Cochrane Database of Systematic Reviews 2011, Issue 1. [DOI: 10.1002/14651858.CD005158.pub3]

* Indicates the major publication for the study

\section{CHARACTERISTICS OF STUDIES}

Characteristics of included studies [ordered by study ID]

\section{ASAP-CABG 2016}

\begin{tabular}{|c|c|c|}
\hline Methods & \multicolumn{2}{|c|}{ Randomized controlled trial. } \\
\hline Participants & \multicolumn{2}{|c|}{ People undergoing CABG with or without cardiopulmonary bypass. } \\
\hline Interventions & \multicolumn{2}{|c|}{$\begin{array}{l}\text { Clopidogrel } 75 \mathrm{mg} \text { daily plus aspirin } 81 \mathrm{mg}(\mathrm{n}=12) \text {. } \\
\text { Aspirin } 81 \mathrm{mg} \text { and placebo }(\mathrm{n}=8) \text {. } \\
\text { For all participants, the first } 30 \text { days consisted of aspirin } 325 \mathrm{mg} \text { daily, after which the dose was de- } \\
\text { creased to } 81 \mathrm{mg} \text { daily. }\end{array}$} \\
\hline Outcomes & \multicolumn{2}{|c|}{$\begin{array}{l}\text { Primary: incidence of } \geq 50 \% \text { stenosis in any graft at } 2 \text { weeks and } 52 \text { weeks after surgery. } \\
\text { Secondary: major adverse cardiovascular events at } 6 \text { months and } 1 \text { year. } \\
\text { Primary safety endpoint: incidence of TIMI major and minor bleeding at } 52 \text { weeks' follow-up. }\end{array}$} \\
\hline \multicolumn{3}{|l|}{ Notes } \\
\hline \multicolumn{3}{|l|}{ Risk of bias } \\
\hline Bias & Authors' judgement & Support for judgement \\
\hline $\begin{array}{l}\text { Random sequence genera- } \\
\text { tion (selection bias) }\end{array}$ & Unclear risk & $\begin{array}{l}\text { "After successful surgery, subjects were randomized to aspirin } 81 \mathrm{mg} \text { daily plus } \\
\text { placebo or aspirin } 81 \mathrm{mg} \text { daily plus clopidogrel } 75 \mathrm{mg} \text { daily." }\end{array}$ \\
\hline
\end{tabular}


ASAP-CABG 2016 (Continued)

$\begin{aligned} & \text { Allocation concealment } \\ & \text { (selection bias) }\end{aligned} \quad$ Unclear risk
placebo or aspirin $81 \mathrm{mg}$ daily plus clopidogrel $75 \mathrm{mg}$ daily."
(selection bias)

Blinding (performance

bias and detection bias)

All outcomes

\begin{tabular}{|c|c|c|}
\hline $\begin{array}{l}\text { Incomplete outcome data } \\
\text { (attrition bias) } \\
\text { All outcomes }\end{array}$ & Low risk & $\begin{array}{l}\text { "Adherence to treatment at } 2 \text { weeks was } 100 \% \text { for each arm and at } 1 \text { year was } \\
50 \% \text { in the DAPT [dual antiplatelet therapy] arm and } 62 \% \text { in the aspirin and } \\
\text { placebo arm." "A treatment compliance analysis was performed restricting the } \\
\text { treatment group to those that completed a full } 12 \text { months of therapy." }\end{array}$ \\
\hline
\end{tabular}

\begin{tabular}{lll}
\hline $\begin{array}{l}\text { Selective reporting (re- } \\
\text { porting bias) }\end{array}$ & Low risk & Outcomes reported as per protocol. \\
\hline Other bias & High risk & $\begin{array}{l}\text { Pharmaceutical industry funded: the study was partially funded for providing } \\
\text { active therapy and placebo only. }\end{array}$ \\
\hline
\end{tabular}

\section{CASCADE 2010}

\begin{tabular}{|c|c|c|}
\hline Methods & \multicolumn{2}{|c|}{ Randomized controlled trial. } \\
\hline Participants & \multicolumn{2}{|c|}{$\begin{array}{l}\text { People undergoing primary multivessel CABG with } \geq 2 \text { SVGs, with or without the use of cardiopul- } \\
\text { monary bypass. }\end{array}$} \\
\hline Interventions & \multicolumn{2}{|c|}{$\begin{array}{l}\text { Clopidogrel } 75 \mathrm{mg} \text { daily plus aspirin } 162 \mathrm{mg}(\mathrm{n}=56 \text {; mean age }( \pm \mathrm{SD}) 64.9 \pm 7.5 \text { years; ma } \\
\text { Aspirin } 162 \mathrm{mg} \text { plus placebo }(n=57 \text {; mean age }( \pm \text { SD) } 68.1 \pm 7.4 \text { years; male sex } 87.7 \%) \text {. }\end{array}$} \\
\hline Outcomes & \multicolumn{2}{|c|}{$\begin{array}{l}\text { Primary: mean SVG intimal area per participant. } \\
\text { Secondary: angiographic SVG patency, major adverse cardiovascular events (cardiovascular death, } \\
\text { MI, cerebrovascular accident, hospitalisation for coronary ischaemia, need for coronary intervention), } \\
\text { episodes of major and minor bleeding. }\end{array}$} \\
\hline \multicolumn{3}{|l|}{ Notes } \\
\hline \multicolumn{3}{|l|}{ Risk of bias } \\
\hline Bias & Authors' judgement & Support for judgement \\
\hline $\begin{array}{l}\text { Random sequence genera- } \\
\text { tion (selection bias) }\end{array}$ & Low risk & $\begin{array}{l}\text { "Randomization was stratified according to the surgical center, the presence } \\
\text { or absence of diabetes mellitus, and the use or nonuse of cardiopulmonary by- } \\
\text { pass during CABG [coronary artery bypass graft]. A block randomization sched- } \\
\text { ule was generated by use of SAS } 9.1 \text { software (SAS, Cary, NC)." }\end{array}$ \\
\hline $\begin{array}{l}\text { Allocation concealment } \\
\text { (selection bias) }\end{array}$ & Low risk & $\begin{array}{l}\text { "Treatment assignment was coordinated by the hospital pharmacies, and all } \\
\text { patients and study personnel were blinded to the treatment assignment. The } \\
\text { extent of platelet inhibition was not assessed in the present study to avoid un- } \\
\text { masking the patients' assigned treatment regimen." }\end{array}$ \\
\hline $\begin{array}{l}\text { Blinding (performance } \\
\text { bias and detection bias) } \\
\text { All outcomes }\end{array}$ & Low risk & $\begin{array}{l}\text { "... we conducted a double-blind, placebo-controlled trial." "Patients ... were } \\
\text { randomly assigned to receive either clopidogrel } 75 \text { mg or an identical-looking } \\
\text { placebo once daily." }\end{array}$ \\
\hline
\end{tabular}


CASCADE 2010 (Continued)
Incomplete outcome data
Low risk
All randomised participants were analysed.
(attrition bias)

All outcomes

Selective reporting (re- Low risk $\quad$ Outcomes reported as per protocol.
porting bias)

\begin{tabular}{ll}
\hline Other bias $\quad$ High risk $\quad$ Pharmaceutical industry funded. \\
\hline
\end{tabular}

\section{CASPAR 2010}

\begin{tabular}{ll}
\hline Methods & Randomized controlled trial. \\
\hline Participants & $\begin{array}{l}851 \text { people receiving a unilateral below knee bypass graft (venous or prosthetic) for the treatment of } \\
\text { peripheral arterial disease. }\end{array}$ \\
\hline Interventions & Clopidogrel $75 \mathrm{mg}(\mathrm{n}=425 ;$ mean age $( \pm \mathrm{SD}) 66.5 \pm 8.7$ years, male sex $75.5 \%)$ daily plus aspirin $75-100$ \\
& Pg daily for $6-24$ months. \\
& Placebo ( $\mathrm{n}=426$; mean age $( \pm \mathrm{SD}) 65.6 \pm 8.5$ years, male sex $75.8 \%)$ plus aspirin $75-100$ mg daily for $6-24$ \\
& $\begin{array}{l}\text { Median duration of follow-up: clopidogrel group: } 364 \text { days (range: } 1-598) ; \text { placebo group: } 364 \text { days } \\
\text { (range: } 2-598) .\end{array}$ \\
\hline Outcomes & $\begin{array}{l}\text { Primary: first occurrence over the duration of follow-up of the following cluster of events: occlusion of } \\
\text { the index bypass graft documented by any imaging procedure (e.g. duplex ultrasonography scan in- } \\
\text { cluding B-mode imaging and Doppler ultrasound scan); or any surgical or endovascular revasculariza- } \\
\text { tion procedure on the index bypass graft or para-anastomotic region; or amputation above the ankle of } \\
\text { the index limb; or death. }\end{array}$ \\
\hline
\end{tabular}

Notes

\section{Risk of bias}

\begin{tabular}{|c|c|c|}
\hline Bias & Authors' judgement & Support for judgement \\
\hline $\begin{array}{l}\text { Random sequence genera- } \\
\text { tion (selection bias) }\end{array}$ & Low risk & $\begin{array}{l}\text { "... using a pre-established randomization scheme, stratified according to the } \\
\text { graft type (venous or prosthetic, with the latter class including any composite } \\
\text { graft in which prosthetic material was used)." }\end{array}$ \\
\hline $\begin{array}{l}\text { Allocation concealment } \\
\text { (selection bias) }\end{array}$ & Low risk & $\begin{array}{l}\text { "Study-drug assignment was performed centrally by an interactive voice-re- } \\
\text { sponse system..." }\end{array}$ \\
\hline $\begin{array}{l}\text { Blinding (performance } \\
\text { bias and detection bias) } \\
\text { All outcomes }\end{array}$ & Low risk & "... randomized, double-blind, placebo-controlled..." \\
\hline $\begin{array}{l}\text { Incomplete outcome data } \\
\text { (attrition bias) } \\
\text { All outcomes }\end{array}$ & Low risk & $\begin{array}{l}\text { Several participants permanently discontinued treatment or were withdrawn } \\
\text { from the study but these were reported in a flow-diagram (Figure } 2 \text { of the pa- } \\
\text { per) and the intention-to-treat analysis included all the } 851 \text { randomised partic- } \\
\text { ipants. }\end{array}$ \\
\hline $\begin{array}{l}\text { Selective reporting (re- } \\
\text { porting bias) }\end{array}$ & Low risk & Outcomes reported as per protocol. \\
\hline
\end{tabular}


CASPAR 2010 (Continued)

Other bias High risk Pharmaceutical industry funded.

\section{CHARISMA 2006}

\begin{tabular}{ll} 
Methods & Randomized controlled trial. \\
\hline Participants & 15,603 people at high risk of a cardiovascular event (both primary and secondary prevention); aged $\geq$ \\
& 45 years and had 1 of the following conditions: multiple atherothrombotic risk factors (to meet the cri- \\
& terion for enrolment on the basis of multiple risk factors, people were required to have 2 major or 3 mi- \\
nor or 1 major and 2 minor atherothrombotic risk factors), documented coronary disease, documented \\
cerebrovascular disease or documented symptomatic peripheral arterial disease.
\end{tabular}

Interventions

Clopidogrel $75 \mathrm{mg}$ daily plus aspirin $70-162 \mathrm{mg}$ daily $(\mathrm{n}=7802$; mean age 64.0 years, range 39.0-95.0 years; female sex $29.7 \%$ ) for a median of 28 months.

Placebo plus aspirin 70-162 mg daily ( $n=7801$; mean age 64.0 years, range 45.0-93.0; female sex $29.8 \%$ ) for a median of 28 months.

Primary efficacy endpoint: composite of the first occurrence of MI, stroke (of any cause) or death from
cardiovascular causes (including haemorrhage).
Secondary efficacy endpoint: composite of first occurrence of the primary endpoint, or hospitalization
for unstable angina, a TIA or a revascularization procedure (coronary, cerebral, peripheral).
Primary safety endpoint: severe bleeding, which included fatal bleeding and intracranial haemorrhage,
or bleeding that caused haemodynamic compromise requiring blood or fluid replacement, inotropic
support or surgical intervention.

Notes

\section{Risk of bias}

\begin{tabular}{|c|c|c|}
\hline Bias & Authors' judgement & Support for judgement \\
\hline $\begin{array}{l}\text { Random sequence genera- } \\
\text { tion (selection bias) }\end{array}$ & Low risk & $\begin{array}{l}\text { "Study-drug assignment was performed centrally by an interactive voice-re- } \\
\text { sponse system on the basis of a pre-established randomization scheme, strati- } \\
\text { fied according to site." }\end{array}$ \\
\hline $\begin{array}{l}\text { Allocation concealment } \\
\text { (selection bias) }\end{array}$ & Low risk & $\begin{array}{l}\text { "Study-drug assignment was performed centrally by an interactive voice-re- } \\
\text { sponse system on the basis of a pre-established randomization scheme, strati- } \\
\text { fied according to site." }\end{array}$ \\
\hline $\begin{array}{l}\text { Blinding (performance } \\
\text { bias and detection bias) } \\
\text { All outcomes }\end{array}$ & Low risk & $\begin{array}{l}\text { "The CHARISMA trial was a prospective, multicenter, randomized, dou- } \\
\text { ble-blind, placebo-controlled study." }\end{array}$ \\
\hline $\begin{array}{l}\text { Incomplete outcome data } \\
\text { (attrition bias) } \\
\text { All outcomes }\end{array}$ & Low risk & $\begin{array}{l}\text { "Treatment was permanently discontinued by } 20.4 \text { percent of the patients in } \\
\text { the clopidogrel group, as compared with } 18.2 \text { percent in the placebo group } \\
(\mathrm{P}<0.001) \text {. A total of } 4.8 \text { percent of the patients in the clopidogrel group and } 4.9 \\
\text { percent of those in the placebo group discontinued treatment because of an } \\
\text { adverse event }(\mathrm{P}=0.67) . " \text { "Follow-up with respect to the primary efficacy end } \\
\text { point ... was complete in } 99.5 \text { percent of the patients randomly assigned to re- } \\
\text { ceive clopidogrel and aspirin and } 99.6 \text { percent of those randomly assigned to } \\
\text { receive placebo and aspirin." }\end{array}$ \\
\hline
\end{tabular}


CHARISMA 2006 (Continued)

\begin{tabular}{|c|c|c|}
\hline $\begin{array}{l}\text { Selective reporting (re- } \\
\text { porting bias) }\end{array}$ & risk & $\begin{array}{l}\text { Primary outcomes reported as per protocol, but secondary outcomes now in- } \\
\text { clude hospitalization for unstable angina, TIA or revascularization. }\end{array}$ \\
\hline
\end{tabular}

porting bias)

Other bias

High risk

Pharmaceutical industry funded.

\section{CRYSSA 2012}

\begin{tabular}{ll}
\hline Methods & Randomized controlled trial. \\
\hline Participants & $\begin{array}{l}300 \text { consecutive people undergoing isolated off-pump CABG for stable coronary artery disease who re- } \\
\text { ceived } \geq 1 \text { SVG. }\end{array}$ \\
\hline Interventions & $\begin{array}{l}\text { Clopidogrel } 75 \mathrm{mg} \text { plus aspirin } 100 \mathrm{mg}(\mathrm{n}=150 \text {; mean age }( \pm \mathrm{SD}) 59.4 \pm 7.7 \text { years; male sex } 73.3 \%) \text { for } 12 \\
\text { months. }\end{array}$ \\
\hline Aspirin $100 \mathrm{mg}(\mathrm{n}=150 ;$ mean age $( \pm \mathrm{SD}) 58.9 \pm 8.3$ years; male sex $75.3 \%)$ for 12 months. \\
\hline Putcomes & $\begin{array}{l}\text { Secondary: graft occlusion at } 12 \text { months; major and minor bleeding (defined according to the CURE tri- } \\
\text { al); and incidence of MACCEs (composite endpoint including cardiac deaths, any repeat revasculariza- } \\
\text { tion (percutaneous coronary interventions or CABG), cerebrovascular accident and documented MI). }\end{array}$
\end{tabular}

\section{Notes}

\section{Risk of bias}

\begin{tabular}{|c|c|c|}
\hline Bias & Authors' judgement & Support for judgement \\
\hline $\begin{array}{l}\text { Random sequence genera- } \\
\text { tion (selection bias) }\end{array}$ & Low risk & $\begin{array}{l}\text { "Patients ... were randomly assigned to aspirin alone or double antiplatelet } \\
\text { treatment by a computer-generated algorithm and antiplatelet therapy was } \\
\text { initiated." }\end{array}$ \\
\hline $\begin{array}{l}\text { Allocation concealment } \\
\text { (selection bias) }\end{array}$ & Low risk & $\begin{array}{l}\text { "Randomisation was fully blinded without taking account of clinical or demo- } \\
\text { graphic features." }\end{array}$ \\
\hline $\begin{array}{l}\text { Blinding (performance } \\
\text { bias and detection bias) } \\
\text { All outcomes }\end{array}$ & High risk & $\begin{array}{l}\text { "The CRYSSA trial is a prospective randomised controlled study." No placebo } \\
\text { used. }\end{array}$ \\
\hline $\begin{array}{l}\text { Incomplete outcome data } \\
\text { (attrition bias) } \\
\text { All outcomes }\end{array}$ & Low risk & The principal investigator (Dr Mannacio) provided additional data. \\
\hline $\begin{array}{l}\text { Selective reporting (re- } \\
\text { porting bias) }\end{array}$ & Unclear risk & No protocol available. \\
\hline Other bias & Unclear risk & No data on funds. \\
\hline
\end{tabular}

\section{CURE 2001}

Methods Randomized controlled trial.


CURE 2001 (Continued)

Participants 12,562 people with acute coronary syndromes without ST-segment elevation.

Interventions Clopidogrel loading dose $300 \mathrm{mg}$ followed by $75 \mathrm{mg}$ daily plus aspirin $75-325 \mathrm{mg}$ daily $(\mathrm{n}=6259)$ for
3-12 months.

Placebo plus aspirin $75-325 \mathrm{mg}$ daily $(\mathrm{n}=6303)$ for $3-12$ months.

Outcomes Primary outcomes: composite of death from cardiovascular causes, non-fatal MI or stroke; composite of the first primary outcome or refractory ischaemia.

Secondary outcomes: severe ischaemia, heart failure and need for revascularization.

Safety-related outcomes: bleeding complications, categorized as life-threatening, major ( $\geq 2$ units of blood), or minor.

\section{Notes}

\section{Risk of bias}

\begin{tabular}{lll}
\hline Bias & Authors' judgement & Support for judgement \\
\hline $\begin{array}{ll}\text { Random sequence genera- } \\
\text { tion (selection bias) }\end{array}$ & Low risk & $\begin{array}{l}\text { "Patients were randomly assigned to either the clopidogrel group or the place- } \\
\text { bo group by a central, 24-hour, computerized randomization service. Permut- } \\
\text { ed-block randomization, stratified according to clinical center, was used." }\end{array}$
\end{tabular}

\begin{tabular}{ll}
\hline $\begin{array}{l}\text { Allocation concealment } \\
\text { (selection bias) }\end{array}$ & "Patients were randomly assigned to either the clopidogrel group or the place- \\
& bo group by a central, 24-hour, computerized randomization service. Permut- \\
& ed-block randomization, stratified according to clinical center, was used."
\end{tabular}

\begin{tabular}{|c|c|c|}
\hline $\begin{array}{l}\text { Blinding (performance } \\
\text { bias and detection bias) } \\
\text { All outcomes }\end{array}$ & Low risk & "We undertook a randomized, double-blind, placebo-controlled trial ..." \\
\hline $\begin{array}{l}\text { Incomplete outcome data } \\
\text { (attrition bias) } \\
\text { All outcomes }\end{array}$ & Low risk & $\begin{array}{l}\text { "All unrefuted events that occurred up to the end of the scheduled follow-up } \\
\text { period on December } 6,2000 \text {, are included in the analyses. Vital status was as- } \\
\text { certained for } 12,549 \text { of the } 12,562 \text { patients who underwent randomization } \\
\text { (99.9 percent), with } 6 \text { patients in the clopidogrel group and } 7 \text { in the placebo } \\
\text { group lost to follow-up ... A total of } 21.1 \text { percent of the patients in the clopido- } \\
\text { grel group discontinued the study medication permanently, as compared with } \\
18.8 \text { percent in the placebo group." }\end{array}$ \\
\hline
\end{tabular}

Selective reporting (re- Low risk $\quad$ Outcomes reported as per protocol.
porting bias)

\begin{tabular}{lll}
\hline Other bias & High risk & Pharmaceutical industry funded. \\
\hline
\end{tabular}

\section{FASTER 2007}

\begin{tabular}{|c|c|}
\hline Methods & $\begin{array}{l}\text { Randomized controlled trial with } 2 \times 2 \text { factorial design. Participants assigned to clopidogrel or placebo, } \\
\text { and to placebo or simvastatin. }\end{array}$ \\
\hline Participants & $\begin{array}{l}392 \text { people with TIA or a minor ischaemic stroke (defined by a NIHSS score } \leq 3 \text { ), who were randomised } \\
\text { to double placebo or to simvastatin plus placebo. }\end{array}$ \\
\hline & $\begin{array}{l}\text { Baseline characteristics: clopidogrel only: } n=98 \text {, mean age }( \pm \text { SD) } 68.9 \pm 13.0 \text { years, female } 46.9 \% \text {; sim- } \\
\text { vastatin and clopidogrel: } n=100 \text {, mean age }( \pm \text { SD) } 67.1 \pm 12.9 \text { years, female } 39 \% \text {; double placebo: } n=\end{array}$ \\
\hline
\end{tabular}


FASTER 2007 (Continued)

95, mean age $( \pm$ SD) $69.8 \pm 12.3$ years, female $55.8 \%$; simvastatin only: $n=99$, mean age $( \pm$ SD) $66.6 \pm$ 14.2 years, female $47.5 \%$.
Aspirin $81 \mathrm{mg}$ daily (with a loading dose of $162 \mathrm{mg}$ if they were naive to aspirin before study enrolment) plus clopidogrel $300 \mathrm{mg}$ loading dose immediately followed by clopidogrel $75 \mathrm{mg}$ daily $(\mathrm{n}=198)$ for 3 months.

Placebo $(n=194)$ for 3 months.

\section{Outcomes \\ Primary efficacy outcome: stroke (ischaemic or haemorrhagic) within 90 days of randomisation. Stroke severity measured by NIHSS, mRS, and Barthel index scores 90 days after stroke. \\ Secondary outcomes: combination of any stroke, MI and vascular death; combination of any stroke, TIA, acute coronary syndrome or all-cause death.}

Notes Trial stopped early due to failure to recruit participants at the prespecified minimum enrolment rate.

\section{Risk of bias}

\begin{tabular}{lll}
\hline Bias & Authors' judgement & Support for judgement \\
\hline $\begin{array}{l}\text { Random sequence genera- } \\
\text { tion (selection bias) }\end{array}$ & Low risk & $\begin{array}{l}\text { "A blocked randomization procedure generated by the trial biostatistician } \\
\text { was used by the central trial pharmacist to produce identical numbered study } \\
\text { treatment kits containing active drug or matched placebo." }\end{array}$
\end{tabular}

\begin{tabular}{ll}
\hline $\begin{array}{l}\text { Allocation concealment } \\
\text { (selection bias) }\end{array}$ & Low risk \\
& $\begin{array}{l}\text { "A blocked randomization procedure generated by the trial biostatistician } \\
\text { treatment kits containing active drug or matched placebo ... The central phar- } \\
\text { macist, who played no role in the care of the patients, was the only person } \\
\text { aware of treatment allocation." }\end{array}$ \\
\hline
\end{tabular}

\begin{tabular}{|c|c|c|}
\hline $\begin{array}{l}\text { Blinding (performance } \\
\text { bias and detection bias) } \\
\text { All outcomes }\end{array}$ & Low risk & $\begin{array}{l}\text { "The trial was blinded (patients, treating physicians, nurses and study site co- } \\
\text { ordinators). The central pharmacist, who played no role in the care of the pa- } \\
\text { tients, was the only person aware of treatment allocation." }\end{array}$ \\
\hline
\end{tabular}

\begin{tabular}{lll}
\hline $\begin{array}{l}\text { Incomplete outcome data } \\
\text { (attrition bias) } \\
\text { All outcomes }\end{array}$ & Low risk & $\begin{array}{l}\text { Extensively described. "Seven patients (1.8\%) were lost to follow-up and are } \\
\text { assumed not to have had outcome events for the purposes of the analysis." }\end{array}$ \\
\hline $\begin{array}{l}\text { Selective reporting (re- } \\
\text { porting bias) }\end{array}$ & Low risk & Lutcomes reported as per protocol. \\
\hline Other bias & Low risk & $\begin{array}{l}\text { Partially pharmaceutical industry funded. "The clopidogrel placebo was pro- } \\
\text { vided by Sanofi-Aventis; both simvastatin and placebo were provided by Mer- } \\
\text { ck-Frosst Canada. Peer review by the Canadian Institutes of Health Research } \\
\text { mandated the pilot phase of this trial design to determine feasibility. Other } \\
\text { than this aspect of the trial design, none of the trial sponsors played any role } \\
\text { in the trial design, data collection, analysis, interpretation, or in the writing } \\
\text { of the report. The corresponding author had full access to all the data in the } \\
\text { study and had final responsibility for the decision to submit it for publication." }\end{array}$
\end{tabular}

\begin{tabular}{ll}
\hline Methods $\quad$ Randomized controlled trial. \\
\hline
\end{tabular}


Gao 2010 (Continued)

Participants 249 people undergoing primary isolated CABG, with or without cardiopulmonary bypass who received $\geq 1$ SVG.

Interventions

Aspirin $100 \mathrm{mg}$ plus clopidogrel $75 \mathrm{mg}(\mathrm{n}=124$; mean age $( \pm$ SD) $57.9 \pm 8.25$ years, female sex $17.7 \%)$ for 3 months.

Aspirin $100 \mathrm{mg}(\mathrm{n}=125$; mean age $( \pm \mathrm{SD}) 59.8 \pm 7.92$ years, female sex $16.2 \%)$ for 3 months.

Outcomes

Primary: MSCT angiography.

Secondary: MACEs, defined as: cardiogenic death; MI (hospital visit for MI reported by participant or hospital admission for MI reported by cardiologist); and need for revascularization (repeat operation or angioplasty reported by participant or cardiologist) through 3 months after CABG.

\section{Notes}

\section{Risk of bias}

\begin{tabular}{|c|c|c|}
\hline Bias & Authors' judgement & Support for judgement \\
\hline $\begin{array}{l}\text { Random sequence genera- } \\
\text { tion (selection bias) }\end{array}$ & Unclear risk & "Patients with successful CABG surgery were randomly assigned to 2 groups." \\
\hline $\begin{array}{l}\text { Allocation concealment } \\
\text { (selection bias) }\end{array}$ & Unclear risk & "Patients with successful CABG surgery were randomly assigned to 2 groups." \\
\hline $\begin{array}{l}\text { Blinding (performance } \\
\text { bias and detection bias) } \\
\text { All outcomes }\end{array}$ & High risk & $\begin{array}{l}\text { "The current trials were carried out in a single center without placebo con- } \\
\text { trol ... In addition to the MSCTA [multislice computed tomography angiogra- } \\
\text { phy] observers, the investigator and patients were not blinded to the random- } \\
\text { ized allocation." }\end{array}$ \\
\hline $\begin{array}{l}\text { Incomplete outcome data } \\
\text { (attrition bias) } \\
\text { All outcomes }\end{array}$ & Low risk & $\begin{array}{l}\text { "Two-hundred forty-nine cardiac surgery candidates were randomized to } \\
\text { group A [aspirin alone] ( } \mathrm{n}=125) \text { or group AC [aspirin plus clopidogrel] ( } \mathrm{n}=124) \text {. } \\
\text { Of the } 249 \text { participants, } 1(0.4 \%) \text { (from group A) died at } 6 \text { weeks after CABG } \\
\text { surgery. Of the remaining } 248 \text { patients, } 239(96.4 \%) \text { completed a 3-month fol- } \\
\text { low-up, and } 224(90.3 \%) \text { underwent MSCTA. Deaths, numbers and reasons for } \\
\text { loss to follow-up, and numbers contributing to analyses are shown in Figure } \\
\text { 1." }\end{array}$ \\
\hline
\end{tabular}

\begin{tabular}{lll}
\hline $\begin{array}{l}\text { Selective reporting (re- } \\
\text { porting bias) }\end{array}$ & Unclear risk & Mostly reported as per protocol, but major bleeding not reported. \\
\hline Other bias & Low risk & $\begin{array}{l}\text { "This study was supported by the Key Project in the National Science \& Tech- } \\
\text { nology Pillar Program during the 11th 5-Year Plan Period (2006BAI01A09)." }\end{array}$ \\
\hline
\end{tabular}

\section{Gasparovic 2014}

\begin{tabular}{ll}
\hline Methods & Randomized controlled trial. \\
\hline Participants & $\begin{array}{l}\text { Adults scheduled to elective primary CABG. On postoperative day 4, people underwent an aggregome- } \\
\text { try-based assessment of their on-aspirin platelet reactivity. People found to be aspirin-resistant were } \\
\text { randomised into either the control or intervention group. }\end{array}$
\end{tabular}

Interventions Clopidogrel $75 \mathrm{mg}$ plus aspirin $300 \mathrm{mg}(\mathrm{n}=112$; mean age $( \pm \mathrm{SD}) 65 \pm 8$ years; male sex $83 \%)$ for 6 months. 
Gasparovic 2014 (Continued)

Aspirin 300 mg ( $n=110$; mean age $( \pm$ SD) $65 \pm 9$ years; male sex $82 \%)$ for 6 months.

Outcomes Primary: MACCEs at 6 months (composite outcome including all-cause mortality, non-fatal MI, cerebrovascular accident and cardiovascular rehospitalization). Secondary: bleeding events components (Bleeding Academic Research Consortium definitions) and individual MACCE components (BARC type 3, 4 and 5 bleeding events as major bleeding, BARC type 1 and 2 as minor bleeding).

Notes

Prospective randomised study that selectively implemented DAPT after CABG in people with aggregometry-documented aspirin resistance.

\section{Risk of bias}

\begin{tabular}{lll}
\hline Bias & Authors' judgement & Support for judgement \\
\hline $\begin{array}{l}\text { Random sequence genera- } \\
\text { tion (selection bias) }\end{array}$ & Low risk & $\begin{array}{l}\text { Randomization software used for participant allocation into the control or in- } \\
\text { tervention arms. }\end{array}$ \\
\hline $\begin{array}{l}\text { Allocation concealment } \\
\text { (selection bias) }\end{array}$ & Low risk & $\begin{array}{l}\text { Randomization software used for participant allocation into the control or in- } \\
\text { tervention arms. }\end{array}$ \\
\hline $\begin{array}{l}\text { Blinding (performance } \\
\text { bias and detection bias) }\end{array}$ & High risk & Prospective randomised study. Single centre without placebo control. \\
\hline $\begin{array}{l}\text { Incomplete outcome data } \\
\text { (attrition bias) } \\
\text { All outcomes }\end{array}$ & Low risk & $\begin{array}{l}\text { 6-month follow-up completed in 107 (97\%) participants in aspirin monothera- } \\
\text { py group and 112 (98\%) in DAPT group. }\end{array}$ \\
\hline $\begin{array}{l}\text { Selective reporting (re- } \\
\text { porting bias) }\end{array}$ & Low risk & Reported as per protocol. \\
\hline \begin{tabular}{l} 
Other bias \\
\hline
\end{tabular} & Unclear risk & No data on funds. \\
\hline
\end{tabular}

MIRROR 2012

\begin{tabular}{ll}
\hline Methods & Randomized controlled trial. \\
\hline Participants & 80 people with peripheral arterial disease which required PTA alone or PTA with additional stenting of \\
the femoropopliteal lesion if required. Stents used if clinically indicated after primary PTA either be- \\
cause of stenosis of $>30 \%$ after primary PTA or because of flow-limiting dissection after primary PTA. \\
All used stents were Nitinol stents.
\end{tabular}

Interventions $\quad$ Clopidogrel plus aspirin $(n=40$; mean age $( \pm$ SD) $69.8 \pm 8.8$ years, male 19 , female 21$)$ for 6 months.

Placebo plus aspirin ( $n=40$; mean age $( \pm$ SD) $70.2 \pm 11.4$ years, male 23 , female 17$)$ for 6 months.

Outcomes

Primary: concentration of platelet activation markers using the Chandler-Loop vessel model.

Secondary: clinical development of the participants 6 months after the intervention including TLR, restenosis, ankle-brachial index, Rutherford class, serious adverse events and days in hospital because of TLR.

Notes

\section{Risk of bias}


MIRROR 2012 (Continued)

\begin{tabular}{lll} 
Bias & Authors' judgement & Support for judgement \\
\hline $\begin{array}{l}\text { Random sequence genera- } \\
\text { tion (selection bias) }\end{array}$ & Low risk & $\begin{array}{l}\text { "... they were randomised to one of the two treatment groups according to a } \\
\text { lot-generated random list ..." }\end{array}$ \\
\hline $\begin{array}{l}\text { Allocation concealment } \\
\text { (selection bias) }\end{array}$ & Unclear risk & No description. \\
\hline $\begin{array}{l}\text { Blinding (performance } \\
\text { bias and detection bias) } \\
\text { All outcomes }\end{array}$ & Low risk & $\begin{array}{l}\text { "... Medication was given in the form of blister packs to the patients; true and } \\
\text { placebo medication was indistinguishable. The patients were supplied with } \\
\text { the blinded medication for the whole duration of the trial. The patients and in- } \\
\text { vestigators were not informed about the assigned study medication..." }\end{array}$
\end{tabular}

\begin{tabular}{lll}
\hline $\begin{array}{l}\text { Incomplete outcome data } \\
\text { (attrition bias) } \\
\text { All outcomes }\end{array}$ & Low risk & All randomised participants were analysed. \\
\hline $\begin{array}{l}\text { Selective reporting (re- } \\
\text { porting bias) }\end{array}$ & Low risk & Reported as per protocol. \\
\hline Other bias & Low risk & $\begin{array}{l}\text { Investigator-initiated study supported by a pharmaceutical company. "...The } \\
\text { sponsors had no involvement in the design of the trial, collection and analysis } \\
\text { of the data, or writing of the report..." }\end{array}$ \\
\hline
\end{tabular}

\section{PROCLAIM 2009}

\begin{tabular}{ll}
\hline Methods & Randomized controlled trial. \\
\hline Participants & 181 people with metabolic syndrome, an atherothrombotic vascular event or cardiovascular interven- \\
tion $\geq 6$ months earlier, and an $\mathrm{hsCRP}$ level $2-10 \mathrm{mg} / \mathrm{L}$ at screening. Diagnostic criteria for metabolic \\
syndrome included having $\geq 3$ of the 5 National Cholesterol Education Program criteria for metabolic \\
syndrome: triglycerides $\geq 150 \mathrm{mg} / \mathrm{dL}$, systolic blood pressure $\geq 130 \mathrm{mmHg}$ and diastolic blood pressure \\
$>85 \mathrm{mmHg}$, fasting blood glucose $\geq 110 \mathrm{mg} / \mathrm{dL}$, waist circumference $>101.6 \mathrm{~cm}(40$ inches) for men and \\
$>88.9 \mathrm{~cm}$ (35 inches) for women, and high-density lipoprotein cholesterol $<40 \mathrm{mg} / \mathrm{dL}$ for men and $<50$ \\
$\mathrm{mg} / \mathrm{dL}$ for women.
\end{tabular}

Interventions $\quad$ Clopidogrel $75 \mathrm{mg}$ daily plus aspirin $81 \mathrm{mg}$ daily $(\mathrm{n}=89$; mean age $( \pm$ SD) $55.9 \pm 12$ years; range $18.3-82.4$ years; male 43.8\%) for 6 weeks.

Placebo plus aspirin $81 \mathrm{mg}$ daily $(n=92$; mean age $( \pm S D)$ 56.3 \pm 12 years; range 24.4-32.3 years; male $41.3 \%$ ) for 6 weeks.

Outcomes Change from baseline in the levels of high-sensitivity C-reactive protein, CD40 ligand, P-selectin and Nterminal pro-brain natriuretic peptide at 6 weeks.

Notes

Enrolment criteria amended after publication of the CHARISMA study (CHARISMA 2006), which showed that asymptomatic people with multiple atherothrombotic risk factors did not benefit from the addition of clopidogrel to aspirin. The amended enrolment criteria allowed only symptomatic people with a history of an atherothrombotic vascular event or a cardiovascular intervention $>6$ months earlier to be included. Because enrolment proceeded at an extremely slow pace, a decision was made to terminate enrolment early in the study, at 181 participants instead of the initially estimated 360 participants.

\section{Risk of bias}


PROCLAIM 2009 (Continued)

Random sequence genera- Low risk "Randomization to the 2 study arms occurred in a 1:1 ratio using permuted tion (selection bias) blocks of size 4, and subjects were assigned unique identification numbers."

Allocation concealment $\quad$ Unclear risk
(selection bias)

(selection bias)

Blinding (performance Low risk

bias and detection bias)

All outcomes

Incomplete outcome data Low risk

(attrition bias)

All outcomes

Selective reporting (re- Unclear risk No protocol available.
porting bias)

Other bias High risk Pharmaceutical industry funded.

Figure 2 depicted the flow of participants from enrolment to final disposition, including the number and reasons for discontinuation in each group.

SPS3 2012

Methods Randomized controlled trial with $2 \times 2$ factorial design. Eligible people underwent simultaneous randomisation to the antiplatelet intervention (in which both participants and practitioners were unaware of group assignments) and to 1 of 2 groups defined by target levels for systolic blood pressure $(<130$ $\mathrm{mmHg}$ vs $130-149 \mathrm{mmHg}$ ) (with participants and practitioners aware of group assignments).

Participants 3020 participants with recent (<180 days) symptomatic, MRI-confirmed lacunar stroke.

Interventions $\quad$ Aspirin $325 \mathrm{mg}$ enteric-coated daily plus clopidogrel $75 \mathrm{mg}$ daily ( $\mathrm{n}=1517$; mean age 63 years; male sex $62 \%$ ) for mean 3.4 years (range $0-8.2$ years).

Placebo ( $n=1503$; mean age 63 years; male sex 64\%) for mean 3.4 years (range 0-8.2 years).

Outcomes Primary: any ischaemic stroke or intracranial haemorrhage, including subdural hematomas.

Secondary: acute MI and death, classified as having a vascular, non-vascular or unknown cause.

Primary safety: major extracranial haemorrhage, defined as serious or life-threatening bleeding requiring transfusion of red cells or surgery or resulting in permanent functional sequelae or death.

Notes At the recommendation of the data and safety monitoring committee, the antiplatelet component of the trial was stopped by the sponsor 10 months before the planned end date, after completion of the second planned interim analysis, because of futility with respect to the primary outcome coupled with evidence of harm. The component of the trial involving blood-pressure targets is ongoing, and no significant interactions between the 2 interventions have been found with regard to the primary outcome.

\section{Risk of bias}

\begin{tabular}{lll}
\hline Bias & Authors' judgement & Support for judgement \\
\hline $\begin{array}{l}\text { Random sequence genera- } \\
\text { tion (selection bias) }\end{array}$ & Low risk & $\begin{array}{l}\text { "Randomized assignments, stratified according to clinical center and baseline } \\
\text { hypertensive status, were generated with the use of a permuted-block design } \\
\text { (with a variable block size) and protected from previewing." }\end{array}$ \\
\hline
\end{tabular}




\section{SPS3 2012 (Continued)}

Allocation concealment Low risk (selection bias)

"Randomized assignments, stratified according to clinical center and baseline hypertensive status, were generated with the use of a permuted-block design (with a variable block size) and protected from previewing."

$\begin{array}{ll}\begin{array}{l}\text { Blinding (performance } \\ \text { bias and detection bias) }\end{array} & \text { Low risk } \\ \begin{array}{ll}\text { All outcomes } & \text { "Eligible patients underwent simultaneous randomization to the antiplatelet } \\ \text { intervention (in which both patients and practitioners were unaware of group } \\ \text { assignments." }\end{array}\end{array}$

Incomplete outcome data Low risk

(attrition bias)

"Among participants who did not complete the study, $2 \%$ were lost to fol-

All outcomes

low-up, $7 \%$ withdrew consent, $5 \%$ left because of site closure, $1 \%$ withdrew at the physician's request, and $1 \%$ withdrew for other reasons."

\begin{tabular}{|c|c|c|}
\hline $\begin{array}{l}\text { Selective reporting (re- } \\
\text { porting bias) }\end{array}$ & Unclear risk & $\begin{array}{l}\text { Study terminated early due to higher rates of bleeding and mortality in clopi- } \\
\text { dogrel arm. }\end{array}$ \\
\hline
\end{tabular}

porting bias)

Other bias Low risk

\begin{abstract}
Partially pharmaceutical industry funded. "SPS3 was an investigator-initiated trial funded by a cooperative agreement with the National Institute of Neurological Disorders and Stroke (NINDS). Clopidogrel and the matching placebo were donated by Sanofi-Aventis and Bristol-Myers Squibb, but neither company had any involvement in the design or execution of the trial or in the analysis or reporting of the data. There were no confidentiality agreements between the study sponsor (NINDS) and investigators."
\end{abstract}

\section{TEG-CABG}

\begin{tabular}{ll}
\hline Methods & Prospective, open-label randomised controlled trial. \\
\hline Participants & 165 participants randomised. Participants undergoing CABG procedure were preoperatively identi- \\
& $\begin{array}{l}\text { fied with a hypercoagulable state by TEG. People were eligible if they were undergoing an isolated elec- } \\
\text { tive or urgent CABG procedure, TEG maximum amplitude } \geq 69 \mathrm{~mm}, \text { aged } \geq 18 \text { years and able to give in- } \\
\text { formed consent. }\end{array}$
\end{tabular}

Interventions Aspirin $75 \mathrm{mg}$ (started within 6-24 hours after surgery) plus clopidogrel bolus dose $300 \mathrm{mg}$ (day 2 postoperatively) follow by $75 \mathrm{mg}(\mathrm{n}=79$, mean age $( \pm$ SD) $65.2 \pm 10.3$ years, female sex 26$)$, for 3 months.

Aspirin $75 \mathrm{mg}(\mathrm{n}=81$, mean age $( \pm \mathrm{SD}) 66.6 \pm 8.5$ years, female sex 25$)$ for 3 months.

Outcomes Primary: graft patency assessed at 3 months by MSCT.

Secondary: thromboembolic events and death; postprocedural day 4 coagulability itself as an independent factor of graft occlusion, thromboembolic events or death; platelet inhibition and its relation to graft patency, thromboembolic events and death.

All outcomes evaluated 3 months after surgery.

Based on the sample size calculation, they decided to enrol 2 groups of 125 participants each, but
study committee decided to terminate the study before completion, after 165 participants had been
randomised (66\%).

\section{Risk of bias}

\begin{tabular}{lll}
\hline Bias & Authors' judgement & Support for judgement \\
\hline $\begin{array}{l}\text { Random sequence genera- } \\
\text { tion (selection bias) }\end{array}$ & Unclear risk & $\begin{array}{l}\text { Prospective, open-label, randomised controlled trial. Participants were ran- } \\
\text { domised (ratio 1:1) to } 1 \text { of } 2 \text { groups utilizing sequentially numbered randomly } \\
\text { sequenced opaque sealed envelopes on day before surgery. }\end{array}$ \\
\hline
\end{tabular}


TEG-CABG (Continued)

\begin{tabular}{|c|c|c|}
\hline $\begin{array}{l}\text { Allocation concealment } \\
\text { (selection bias) }\end{array}$ & Low risk & $\begin{array}{l}\text { Prospective, open-label, randomised controlled trial. Participants were ran- } \\
\text { domised (ratio } 1: 1 \text { ) to } 1 \text { of } 2 \text { groups utilizing sequentially numbered randomly } \\
\text { sequenced opaque sealed envelopes on day before surgery. }\end{array}$ \\
\hline
\end{tabular}

\begin{tabular}{|c|c|c|}
\hline $\begin{array}{l}\text { Blinding (performance } \\
\text { bias and detection bias) } \\
\text { All outcomes }\end{array}$ & High risk & "...open-label design." \\
\hline $\begin{array}{l}\text { Incomplete outcome data } \\
\text { (attrition bias) } \\
\text { All outcomes }\end{array}$ & Low risk & $\begin{array}{l}165 \text { participants randomised. Data from } 133 \text { participants available for analysis } \\
\text { of all outcomes, and data from } 160 \text { participants available for analysis of sec- } \\
\text { ondary outcome of thromboembolic complications and death. }\end{array}$ \\
\hline $\begin{array}{l}\text { Selective reporting (re- } \\
\text { porting bias) }\end{array}$ & Low risk & Reported as per protocol. \\
\hline Other bias & Low risk & $\begin{array}{l}\text { Author received a non-restricted partial resident research grant for this study } \\
\text { from the Danish Heart Foundation. }\end{array}$ \\
\hline
\end{tabular}

Vavuranakis 2006

\begin{tabular}{|c|c|c|}
\hline Methods & \multicolumn{2}{|c|}{ Randomized controlled trial. } \\
\hline Participants & \multicolumn{2}{|c|}{$\begin{array}{l}86 \text { people with acute non-ST elevation coronary syndrome (mean age ( } \pm \text { SD) } 68 \pm 3 \text { years, } 71 \text { men, } 15 \\
\text { women). People eligible if they had ECG changes suggestive of ischaemia or positive serum markers of } \\
\text { cardiac damage (troponin I concentration, }>0.4 \mathrm{ng} / \mathrm{mL} \text { ) (or both), or without new ECG changes on se- } \\
\text { rial ECGs but with a history of coronary artery disease (defined as a history of acute MI, CABG surgery, } \\
\text { coronary angioplasty, coronary artery stenosis }>50 \% \text { on coronary angiography, or a combination of } \\
\text { these). }\end{array}$} \\
\hline Interventions & \multicolumn{2}{|c|}{$\begin{array}{l}\text { Aspirin } 325 \mathrm{mg} \text { daily for } 1 \text { week, followed by aspirin } 100 \mathrm{mg} \text { daily plus clopidogrel } 300 \mathrm{mg} \text { loading dose } \\
\text { followed by } 100 \mathrm{mg} \text { daily for } 36 \text { weeks }(n=43)\end{array}$} \\
\hline & \multicolumn{2}{|c|}{ Aspirin 325 mg daily for 1 week, followed by aspirin $75 \mathrm{mg}$ daily for 36 weeks $(n=43$ ). } \\
\hline Outcomes & \multicolumn{2}{|c|}{ Primary: plasma P-selectin level. } \\
\hline & \multicolumn{2}{|c|}{$\begin{array}{l}\text { Secondary: MACEs (which included nonfatal MI, recurrent ischaemia and cardiovascular-related death) } \\
\text { and relationship between P-selectin and hsCRP and SCD40L levels. }\end{array}$} \\
\hline \multicolumn{3}{|l|}{ Notes } \\
\hline \multicolumn{3}{|l|}{ Risk of bias } \\
\hline Bias & Authors' judgement & Support for judgement \\
\hline $\begin{array}{l}\text { Random sequence genera- } \\
\text { tion (selection bias) }\end{array}$ & Unclear risk & $\begin{array}{l}\text { Eligible people were randomised using a computer-derived randomisation } \\
\text { schedule with a } 4 \times 2 \text { permuted block to ensure equal distribution between } \\
\text { groups. }\end{array}$ \\
\hline $\begin{array}{l}\text { Allocation concealment } \\
\text { (selection bias) }\end{array}$ & Unclear risk & Not reported. \\
\hline $\begin{array}{l}\text { Blinding (performance } \\
\text { bias and detection bias) } \\
\text { All outcomes }\end{array}$ & High risk & Single-blind. \\
\hline
\end{tabular}


Vavuranakis 2006 (Continued)

Incomplete outcome data Low risk A similar proportion of patients in each arm (14\% of clopidogrel +aspirin vs. (attrition bias)

All outcomes

\begin{tabular}{lll}
$\begin{array}{l}\text { Selective reporting (re- } \\
\text { porting bias) }\end{array}$ & Unclear risk & No protocol available. \\
\hline Other bias & Low risk & No funds from pharmaceutical industry. \\
\hline
\end{tabular}

Zuo 2017

\begin{tabular}{|c|c|}
\hline Methods & Prospective, randomised (1:1:1), single-centre study. \\
\hline \multirow[t]{3}{*}{ Participants } & 200 participants included; median age 62 years, 79 (39.5\%) females. \\
\hline & $\begin{array}{l}\text { Inclusive criteria: aged } 45-80 \text { years; diagnosis of an acute cerebral infarction or TIA; > 50\% stenosis of } \\
\text { internal carotid artery, middle cerebral artery, vertebral artery, basilar artery and posterior cerebral } \\
\text { artery alone or in combination; unsuitable or reluctance to perform stent implantation. }\end{array}$ \\
\hline & $\begin{array}{l}\text { Among } 200 \text { participants, } 66 \text { received clopidogrel } 50 \mathrm{mg} \text { plus aspirin, } 66 \text { received clopidogrel } 75 \mathrm{mg} \text { plus } \\
\text { aspirin, } 68 \text { received aspirin alone. }\end{array}$ \\
\hline \multirow[t]{3}{*}{ Interventions } & Aspirin alone $100 \mathrm{mg}$ ( $\mathrm{n}=68$, median age 62.29 years, range $45-80$ years, 27 female) on days 1-90. \\
\hline & $\begin{array}{l}\text { Clopidogrel } 50 \mathrm{mg} \text { plus aspirin } 100 \mathrm{mg}(\mathrm{n}=66 \text {, median age } 61.58 \text { years, range } 45-80 \text { years, } 28 \text { female) on } \\
\text { days } 1-90 .\end{array}$ \\
\hline & $\begin{array}{l}\text { Clopidogrel } 75 \mathrm{mg} \text { plus aspirin } 100 \mathrm{mg}(\mathrm{n}=66 \text {, median age } 61.55 \text { years, range } 45-80 \text { years, } 24 \text { female) on } \\
\text { days } 1-90 .\end{array}$ \\
\hline
\end{tabular}

Outcomes

Recurrence of ischaemic stroke, death from any causes and death from cardiovascular causes (including haemorrhage) in the first 90 days after cerebral infarction or TIA.

Several haemorrhagic events monitored based on the GUSTO definition. Nasal and gum bleeding.

Notes

For our review, we considered only the 2 groups of participants taking aspirin $100 \mathrm{mg}$ plus clopidogrel

$75 \mathrm{mg}$ and aspirin $100 \mathrm{mg}$ alone because no other study in this review used aspirin plus low-dose clopi-

dogrel $(50 \mathrm{mg}$ ) as intervention group.

\section{Risk of bias}

\begin{tabular}{|c|c|c|}
\hline Bias & Authors' judgement & Support for judgement \\
\hline $\begin{array}{l}\text { Random sequence genera- } \\
\text { tion (selection bias) }\end{array}$ & Unclear risk & $\begin{array}{l}\text { Prospective, randomised, single-centre. "Patients were randomly assigned } \\
\text { (1:1:1) to receive aspirin alone (100mg), or clopidogrel (50mg) plus aspirin (100 } \\
\text { mg), or clopidogrel ( } 75 \mathrm{mg}) \text { plus aspirin (100mg)." }\end{array}$ \\
\hline $\begin{array}{l}\text { Allocation concealment } \\
\text { (selection bias) }\end{array}$ & Unclear risk & $\begin{array}{l}\text { "Patients were randomly assigned }(1: 1: 1) \text { to receive aspirin alone }(100 \mathrm{mg}) \text {, or } \\
\text { clopidogrel (50mg) plus aspirin }(100 \mathrm{mg}) \text {, or clopidogrel }(75 \mathrm{mg}) \text { plus aspirin } \\
\text { (100mg)." }\end{array}$ \\
\hline $\begin{array}{l}\text { Blinding (performance } \\
\text { bias and detection bias) } \\
\text { All outcomes }\end{array}$ & High risk & $\begin{array}{l}\text { Single centre without placebo control. Not specified if the investigator and } \\
\text { participants were blinded to the randomised allocation. }\end{array}$ \\
\hline $\begin{array}{l}\text { Incomplete outcome data } \\
\text { (attrition bias) }\end{array}$ & Low risk & $\begin{array}{l}90 \text { days' treatment and follow-up. All } 200 \text { participants completed the treat- } \\
\text { ment. }\end{array}$ \\
\hline
\end{tabular}


Zuo 2017 (Continued)

All outcomes

\begin{tabular}{lll}
\hline $\begin{array}{l}\text { Selective reporting (re- } \\
\text { porting bias) }\end{array}$ & Unclear risk & No protocol available. \\
\hline Other bias & Low risk & $\begin{array}{l}\text { Funding: study supported by a grant from the Science and Technology Bureau } \\
\text { of Cangzhou City, Hebei Province, China. }\end{array}$
\end{tabular}

CABG: coronary artery bypass graft; DAPT: dual antiplatelet therapy; ECG: electrocardiograph; GUSTO : Global Utilization of Streptokinase and Tissue Plasminogen Activator for Occluded Coronary Arteries; hSCRP: high sensitivity C-reactive protein; MACCE: major adverse cardiac and cerebrovascular event; MI: myocardial infarction; MRI: magnetic resonance imaging; mRS: modified Rankin Scale; MSCT: multislice computed tomography; n: number of participants; NIHSS: National Institutes of Health Stroke Scale; PTA: percutaneous transluminal angioplasty; SCD40L: soluble CD40-ligand; SD: standard deviation; SVG: saphenous vein graft; TEG: thrombelastography; TIA: transient ischaemic attack; TIMI: thrombolysis In myocardial infarction; TLR: target lesion revascularization.

\section{Characteristics of excluded studies [ordered by study ID]}

\begin{tabular}{|c|c|}
\hline Study & Reason for exclusion \\
\hline Akbulut 2004 & No clinical endpoints reported. \\
\hline ARTE & $\begin{array}{l}\text { Participants undergoing a TAVI procedure with the Edwards SAPIEN XT valve (transfemoral or } \\
\text { transapical) instead of people at high-risk of cardiovascular or cerebrovascular events. Ongoing tri- } \\
\text { al; estimated study completion date: January } 2017 .\end{array}$ \\
\hline Azar 2006 & No clinical endpoints reported. \\
\hline Azcona 2012 & No clinical endpoints reported. \\
\hline Bernardi 2007 & Only participants with coronary stents. \\
\hline CARESS 2005 & Clopidogrel and placebo administered for only 7 days. \\
\hline Cassar 2005 & Only data for the first 30 days of therapy administration. \\
\hline CHANCE 2013 & Clopidogrel plus aspirin administered for only 21 days. \\
\hline CLAIR 2010 & Clopidogrel plus aspirin administered for only 7 days; 7 -day study period. \\
\hline CLARITY-TIMI 282005 & Only data for the first 30 days of clopidogrel plus aspirin administration. \\
\hline COMMIT 2005 & Clopidogrel and placebo administered only until discharge or for up to 4 weeks in hospital. \\
\hline CREDO 2002 & Placebo group received clopidogrel for 1 month after $\mathrm{PCl}$. \\
\hline Eriksson 2009 & $\begin{array}{l}\text { Participants receiving clopidogrel plus aspirin were randomised to single clopidogrel or to single } \\
\text { aspirin in a cross-over study design. }\end{array}$ \\
\hline EXCELLENT 2012 & Only people with coronary stents. \\
\hline Geraghty 2010 & No proper study design. \\
\hline Hong 2016 & Clopidogrel plus aspirin was administered for only 30 days. 30 days' follow-up. \\
\hline Hui 2016 & $\begin{array}{l}\text { Ongoing study. In the dual antiplatelet drugs therapy group (aspirin plus clopidogrel), clopidogrel } \\
\text { was given only for the first } 14 \text { days. }\end{array}$ \\
\hline
\end{tabular}




\begin{tabular}{|c|c|}
\hline Study & Reason for exclusion \\
\hline Jagroop 2004 & No clinical endpoints reported. \\
\hline Kayacioglu 2008 & No clinical endpoints reported. \\
\hline MATCH 2004 & Clopidogrel plus aspirin compared to clopidogrel alone. \\
\hline Mujanovic 2009 & No clinical endpoints reported. \\
\hline ONSET/OFFSET 2010 & No clinical endpoints reported. Investigators stated that clinical endpoints were not collected. \\
\hline Pal 2016 & Lack of data (conference abstract). Investigators could not be contacted due to lack of detail. \\
\hline Pekdemir 2003 & Comparison of 1 month vs 6 months of clopidogrel after PCl. \\
\hline PRODIGY 2012 & Only people with coronary stents. \\
\hline REAL-LATE/ZEST-LATE 2010 & Only people with coronary stents. \\
\hline RESET 2012 & Only people with coronary stents. \\
\hline Steinhubl 2006 & Only data for the first 28 days of therapy and on different clopidogrel loading doses. \\
\hline Suh 2011 & Only data for the first 28 days of clopidogrel plus aspirin administration. \\
\hline Thopte 2014 & $\begin{array}{l}\text { Lack of data (conference abstract). Investigators could not be contacted due to lack of available } \\
\text { detail. }\end{array}$ \\
\hline Undas 2009 & No clinical endpoints reported. Clopidogrel plus aspirin administered for only 4 weeks. \\
\hline Ussia 2011 & People undergoing TAVI instead of people at high-risk of cardiovascular or cerebrovascular events. \\
\hline Wang 2015 & Clopidogrel plus aspirin administered for only 30 days. \\
\hline Willoughby 2014 & No clinical endpoints reported. \\
\hline Wilson 2009 & No clinical endpoints reported. Clopidogrel plus aspirin administered for only 30 days. \\
\hline Xydakis 2004 & Clopidogrel and placebo administered for only 5 days. \\
\hline Yi 2014 & $\begin{array}{l}\text { Clopidogrel plus aspirin administered for only } 30 \text { days; efficacy and safety outcomes reported dur- } \\
\text { ing } 30 \text { days of treatment. }\end{array}$ \\
\hline Zhao 2003 & Clopidogrel and placebo administered for only 2 weeks. \\
\hline
\end{tabular}

PCl: percutaneous coronary intervention; TAVI: transcatheter aortic valve implantation.

Characteristics of ongoing studies [ordered by study ID]

\section{POINT}

Trial name or title Platelet-Oriented Inhibition in New TIA and Minor Ischemic Stroke (POINT) Trial: Rationale and Design.

Methods Randomized controlled trial.


POINT (Continued)

Participants

People aged $\geq 18$ years with high-risk transient ischaemic attack, defined as an ABCD2 score $(23) \geq$ 4 , or minor ischaemic stroke, with a National Institutes of Health Stroke Scale (24) score $\leq 3$, who can be randomised within 12 hours of the time last known free of new ischaemic symptoms.

Interventions $\begin{aligned} & \text { Open-label aspirin } 50-325 \mathrm{mg} / \text { day (dose of } 162 \mathrm{mg} / \text { day for } 5 \text { days, then recommended } 81 \mathrm{mg} / \mathrm{day} \\ & \text { dose) plus clopidogrel } 600 \mathrm{mg} \text { loading dose followed by } 75 \mathrm{mg} / \text { day from day } 2 \text { to day } 90 \text { compared } \\ & \text { with aspirin plus placebo. Each participant is followed for } 90 \text { days from randomisation. }\end{aligned}$

Outcomes Composite of new ischaemic vascular events (ischaemic stroke, myocardial infarction or ischaemic vascular death) up to 90 days; major haemorrhage (definition adapted from International Society on Thrombosis and Haemostasis and PRoFESS (Prevention Regimen for Effectively Avoiding Second Strokes) trial). Secondary analyses: death (all-cause), intracerebral haemorrhage and minor haemorrhage.

\begin{tabular}{ll}
\hline Starting date & October 2009. \\
\hline Contact information & Mary Farrant; email: mary.farrant2@ucsf.edu. \\
\hline Notes & clinicaltrials.gov/ct2/show/NCT00991029. Estimated study completion date: December 2018. \\
\hline
\end{tabular}

DATA AND ANALYSES

\section{Comparison 1. Clopidogrel (Clo) plus aspirin (ASA) versus aspirin alone}

\begin{tabular}{|c|c|c|c|c|}
\hline Outcome or subgroup title & $\begin{array}{l}\text { No. of } \\
\text { studies }\end{array}$ & $\begin{array}{l}\text { No. of } \\
\text { partici- } \\
\text { pants }\end{array}$ & Statistical method & Effect size \\
\hline 1 Cardiovascular mortality & 7 & 31903 & Risk Ratio (M-H, Fixed, 95\% Cl) & $0.98[0.88,1.10]$ \\
\hline $\begin{array}{l}\text { 1.1 Acute coronary syndrome } \\
\text { without ST elevation }\end{array}$ & 2 & 12648 & Risk Ratio (M-H, Fixed, 95\% Cl) & $0.93[0.80,1.08]$ \\
\hline $\begin{array}{l}1.2 \text { Coronary artery bypass } \\
\text { graft (CABG) }\end{array}$ & 3 & 632 & Risk Ratio (M-H, Fixed, 95\% Cl) & $0.55[0.12,2.57]$ \\
\hline 1.3 Ischaemic stroke & 1 & 3020 & Risk Ratio (M-H, Fixed, 95\% Cl) & $1.41[0.79,2.52]$ \\
\hline 1.4 Mixed population & 1 & 15603 & Risk Ratio (M-H, Fixed, 95\% Cl) & $1.04[0.87,1.24]$ \\
\hline 2 All-cause mortality & 9 & 32908 & Risk Ratio (M-H, Random, 95\% Cl) & $1.05[0.87,1.25]$ \\
\hline $\begin{array}{l}2.1 \text { Acute coronary syndrome } \\
\text { without ST elevation }\end{array}$ & 1 & 12562 & Risk Ratio (M-H, Random, 95\% Cl) & $0.93[0.81,1.07]$ \\
\hline 2.2 Ischaemic stroke & 1 & 3020 & Risk Ratio (M-H, Random, 95\% Cl) & $1.45[1.10,1.93]$ \\
\hline $2.3 \mathrm{CABG}$ & 4 & 792 & Risk Ratio (M-H, Random, 95\% Cl) & $0.37[0.13,1.10]$ \\
\hline $\begin{array}{l}\text { 2.4 Peripheral arterial disease } \\
\text { (PAD) }\end{array}$ & 2 & 931 & Risk Ratio (M-H, Random, 95\% Cl) & $1.34[0.74,2.44]$ \\
\hline 2.5 Mixed population & 1 & 15603 & Risk Ratio (M-H, Random, 95\% Cl) & $0.99[0.86,1.14]$ \\
\hline
\end{tabular}




\begin{tabular}{|c|c|c|c|c|}
\hline Outcome or subgroup title & $\begin{array}{l}\text { No. of } \\
\text { studies }\end{array}$ & $\begin{array}{l}\text { No. of } \\
\text { partici- } \\
\text { pants }\end{array}$ & Statistical method & Effect size \\
\hline $\begin{array}{l}3 \text { Fatal and non-fatal myocar- } \\
\text { dial infarction }\end{array}$ & 6 & 16175 & Risk Ratio (M-H, Fixed, 95\% CI) & $0.78[0.69,0.90]$ \\
\hline $\begin{array}{l}\text { 3.1 Acute coronary syndrome } \\
\text { without ST elevation }\end{array}$ & 1 & 12562 & Risk Ratio (M-H, Fixed, 95\% Cl) & $0.78[0.68,0.90]$ \\
\hline 3.2 CABG & 4 & 593 & Risk Ratio (M-H, Fixed, 95\% Cl) & $0.89[0.41,1.92]$ \\
\hline 3.3 Ischaemic stroke & 1 & 3020 & Risk Ratio (M-H, Fixed, 95\% Cl) & $0.81[0.51,1.29]$ \\
\hline $\begin{array}{l}4 \text { Fatal and non-fatal is- } \\
\text { chaemic stroke }\end{array}$ & 5 & 4006 & Risk Ratio (M-H, Fixed, 95\% Cl) & $0.73[0.59,0.91]$ \\
\hline 4.1 CABG & 2 & 460 & Risk Ratio (M-H, Fixed, 95\% Cl) & $0.89[0.33,2.40]$ \\
\hline 4.2 Ischaemic stroke & 3 & 3546 & Risk Ratio (M-H, Fixed, 95\% Cl) & $0.73[0.58,0.91]$ \\
\hline 5 Major bleeding & 10 & 33300 & Risk Ratio (M-H, Fixed, 95\% Cl) & $1.44[1.25,1.64]$ \\
\hline 5.1 Acute coronary syndrome & 1 & 12562 & Risk Ratio (M-H, Fixed, 95\% Cl) & $1.38[1.13,1.67]$ \\
\hline 5.2 CABG & 4 & 792 & Risk Ratio (M-H, Fixed, 95\% Cl) & $1.49[0.69,3.19]$ \\
\hline 5.3 PAD & 2 & 931 & Risk Ratio (M-H, Fixed, 95\% CI) & $1.91[0.69,5.32]$ \\
\hline 5.4 Ischaemic stroke & 2 & 3412 & Risk Ratio (M-H, Fixed, 95\% Cl) & $1.90[1.39,2.60]$ \\
\hline 5.5 Mixed population & 1 & 15603 & Risk Ratio (M-H, Fixed, 95\% CI) & $1.25[0.97,1.61]$ \\
\hline 6 Minor bleeding & 8 & 14731 & Risk Ratio (M-H, Fixed, 95\% Cl) & $2.03[1.75,2.36]$ \\
\hline 6.1 Acute coronary syndrome & 1 & 12562 & Risk Ratio (M-H, Fixed, 95\% CI) & $2.08[1.72,2.51]$ \\
\hline $6.2 \mathrm{CABG}$ & 4 & 792 & Risk Ratio (M-H, Fixed, 95\% Cl) & $1.54[1.04,2.28]$ \\
\hline 6.3 PAD & 1 & 851 & Risk Ratio (M-H, Fixed, 95\% Cl) & $2.20[1.33,3.61]$ \\
\hline 6.4 Ischaemic stroke & 2 & 526 & Risk Ratio (M-H, Fixed, 95\% Cl) & $2.27[1.51,3.39]$ \\
\hline $\begin{array}{l}7 \text { Repeated revascularization } \\
\text { for CABG }\end{array}$ & 2 & 413 & Risk Ratio (M-H, Fixed, 95\% Cl) & $0.50[0.09,2.72]$ \\
\hline $\begin{array}{l}8 \text { Saphenous vein graft paten- } \\
\text { cy for CABG }\end{array}$ & 3 & 662 & Risk Ratio (M-H, Fixed, 95\% Cl) & $1.06[1.01,1.12]$ \\
\hline $\begin{array}{l}9 \text { Amputation for people with } \\
\text { PAD }\end{array}$ & 2 & 931 & Risk Ratio (M-H, Fixed, 95\% Cl) & $0.68[0.44,1.05]$ \\
\hline $\begin{array}{l}10 \text { Sensitivity analysis - ran- } \\
\text { dom-effects model: cardiovas- } \\
\text { cular mortality }\end{array}$ & 7 & 31903 & Risk Ratio (M-H, Random, 95\% Cl) & $0.98[0.88,1.10]$ \\
\hline $\begin{array}{l}\text { 10.1 Acute coronary syndrome } \\
\text { without ST elevation }\end{array}$ & 2 & 12648 & Risk Ratio (M-H, Random, 95\% Cl) & $0.93[0.80,1.08]$ \\
\hline
\end{tabular}




\begin{tabular}{|c|c|c|c|c|}
\hline Outcome or subgroup title & $\begin{array}{l}\text { No. of } \\
\text { studies }\end{array}$ & $\begin{array}{l}\text { No. of } \\
\text { partici- } \\
\text { pants }\end{array}$ & Statistical method & Effect size \\
\hline $10.2 \mathrm{CABG}$ & 3 & 632 & Risk Ratio (M-H, Random, 95\% Cl) & $0.56[0.12,2.70]$ \\
\hline 10.3 Ischaemic stroke & 1 & 3020 & Risk Ratio (M-H, Random, 95\% Cl) & $1.41[0.79,2.52]$ \\
\hline 10.4 Mixed population & 1 & 15603 & Risk Ratio (M-H, Random, 95\% Cl) & $1.04[0.87,1.24]$ \\
\hline $\begin{array}{l}11 \text { Sensitivity analysis - ran- } \\
\text { dom-effects model: fatal and } \\
\text { non-fatal myocardial infarc- } \\
\text { tion }\end{array}$ & 6 & 16175 & Risk Ratio (M-H, Random, 95\% Cl) & $0.78[0.68,0.89]$ \\
\hline $\begin{array}{l}\text { 11.1 Acute coronary syndrome } \\
\text { without ST elevation }\end{array}$ & 1 & 12562 & Risk Ratio (M-H, Random, 95\% Cl) & $0.78[0.68,0.90]$ \\
\hline $11.2 \mathrm{CABG}$ & 4 & 593 & Risk Ratio (M-H, Random, 95\% Cl) & $0.83[0.36,1.91]$ \\
\hline 11.3 Ischaemic stroke & 1 & 3020 & Risk Ratio (M-H, Random, 95\% Cl) & $0.81[0.51,1.29]$ \\
\hline $\begin{array}{l}12 \text { Sensitivity analysis - ran- } \\
\text { dom-effects model: fatal and } \\
\text { non-fatal ischaemic stroke }\end{array}$ & 5 & 4006 & Risk Ratio (M-H, Random, 95\% Cl) & $0.69[0.50,0.96]$ \\
\hline $12.1 \mathrm{CABG}$ & 2 & 460 & Risk Ratio (M-H, Random, 95\% Cl) & $0.91[0.33,2.51]$ \\
\hline 12.2 Ischaemic stroke & 3 & 3546 & Risk Ratio (M-H, Random, 95\% Cl) & $0.63[0.40,1.00]$ \\
\hline $\begin{array}{l}13 \text { Sensitivity analysis - ran- } \\
\text { dom-effects model: major } \\
\text { bleeding }\end{array}$ & 10 & 33300 & Risk Ratio (M-H, Random, 95\% Cl) & $1.43[1.25,1.64]$ \\
\hline $\begin{array}{l}13.1 \text { Acute coronary syndrome } \\
\text { without ST elevation }\end{array}$ & 1 & 12562 & Risk Ratio (M-H, Random, 95\% Cl) & $1.38[1.13,1.67]$ \\
\hline 13.2 CABG & 4 & 792 & Risk Ratio (M-H, Random, 95\% Cl) & $1.41[0.65,3.07]$ \\
\hline 13.3 PAD & 2 & 931 & Risk Ratio (M-H, Random, 95\% Cl) & $1.90[0.68,5.31]$ \\
\hline 13.4 Ischaemic stroke & 2 & 3412 & Risk Ratio (M-H, Random, 95\% Cl) & $1.89[1.38,2.58]$ \\
\hline 13.5 Mixed population & 1 & 15603 & Risk Ratio (M-H, Random, 95\% Cl) & $1.25[0.97,1.61]$ \\
\hline $\begin{array}{l}14 \text { Sensitivity analysis - ran- } \\
\text { dom-effects model: minor } \\
\text { bleeding }\end{array}$ & 8 & 14731 & Risk Ratio (M-H, Random, 95\% Cl) & $2.02[1.74,2.35]$ \\
\hline $\begin{array}{l}\text { 14.1 Acute coronary syndrome } \\
\text { without ST elevation }\end{array}$ & 1 & 12562 & Risk Ratio (M-H, Random, 95\% Cl) & $2.08[1.72,2.51]$ \\
\hline $14.2 \mathrm{CABG}$ & 4 & 792 & Risk Ratio (M-H, Random, 95\% Cl) & $1.52[1.01,2.31]$ \\
\hline 14.3 PAD & 1 & 851 & Risk Ratio (M-H, Random, 95\% Cl) & $2.20[1.33,3.61]$ \\
\hline 14.4 Ischaemic stroke & 2 & 526 & Risk Ratio (M-H, Random, 95\% Cl) & $2.25[1.50,3.37]$ \\
\hline
\end{tabular}




\begin{tabular}{|c|c|c|c|c|}
\hline Outcome or subgroup title & $\begin{array}{l}\text { No. of } \\
\text { studies }\end{array}$ & $\begin{array}{l}\text { No. of } \\
\text { partici- } \\
\text { pants }\end{array}$ & Statistical method & Effect size \\
\hline $\begin{array}{l}15 \text { Sensitivity analysis - ran- } \\
\text { dom-effects model: repeated } \\
\text { revascularization for people } \\
\text { with CABG }\end{array}$ & 2 & 413 & Risk Ratio (M-H, Random, 95\% Cl) & $0.50[0.09,2.72]$ \\
\hline $\begin{array}{l}16 \text { Sensitivity analysis - ran- } \\
\text { dom-effects model: SVG pa- } \\
\text { tency for people with CABG }\end{array}$ & 3 & 662 & Risk Ratio (M-H, Random, 95\% Cl) & $1.06[1.01,1.11]$ \\
\hline $\begin{array}{l}17 \text { Sensitivity analysis - ran- } \\
\text { dom-effects model: amputa- } \\
\text { tion for people with PAD }\end{array}$ & 2 & 931 & Risk Ratio (M-H, Random, 95\% Cl) & $0.68[0.44,1.05]$ \\
\hline $\begin{array}{l}18 \text { Sensitivity analysis - low } \\
\text { risk of bias (RoB): cardiovascu- } \\
\text { lar mortality }\end{array}$ & 2 & 12675 & Risk Ratio (M-H, Fixed, 95\% Cl) & $0.93[0.80,1.07]$ \\
\hline $\begin{array}{l}19 \text { Sensitivity analysis - low } \\
\text { RoB: all-cause mortality }\end{array}$ & 3 & 13526 & Risk Ratio (M-H, Random, 95\% Cl) & $0.97[0.78,1.20]$ \\
\hline $\begin{array}{l}20 \text { Sensitivity analysis - low } \\
\text { RoB: fatal and non-fatal my- } \\
\text { ocardial infarction }\end{array}$ & 2 & 12675 & Risk Ratio (M-H, Fixed, 95\% Cl) & $0.79[0.68,0.90]$ \\
\hline $\begin{array}{l}21 \text { Sensitivity analysis - low } \\
\text { RoB: major bleeding }\end{array}$ & 4 & 13918 & Risk Ratio (M-H, Fixed, 95\% Cl) & $1.41[1.16,1.71]$ \\
\hline $\begin{array}{l}22 \text { Sensitivity analysis - low } \\
\text { RoB: minor bleeding }\end{array}$ & 4 & 13918 & Risk Ratio (M-H, Fixed, 95\% Cl) & $2.09[1.78,2.46]$ \\
\hline
\end{tabular}

\section{Analysis 1.1. Comparison 1 Clopidogrel (Clo) plus aspirin (ASA) versus aspirin alone, Outcome 1 Cardiovascular mortality.}

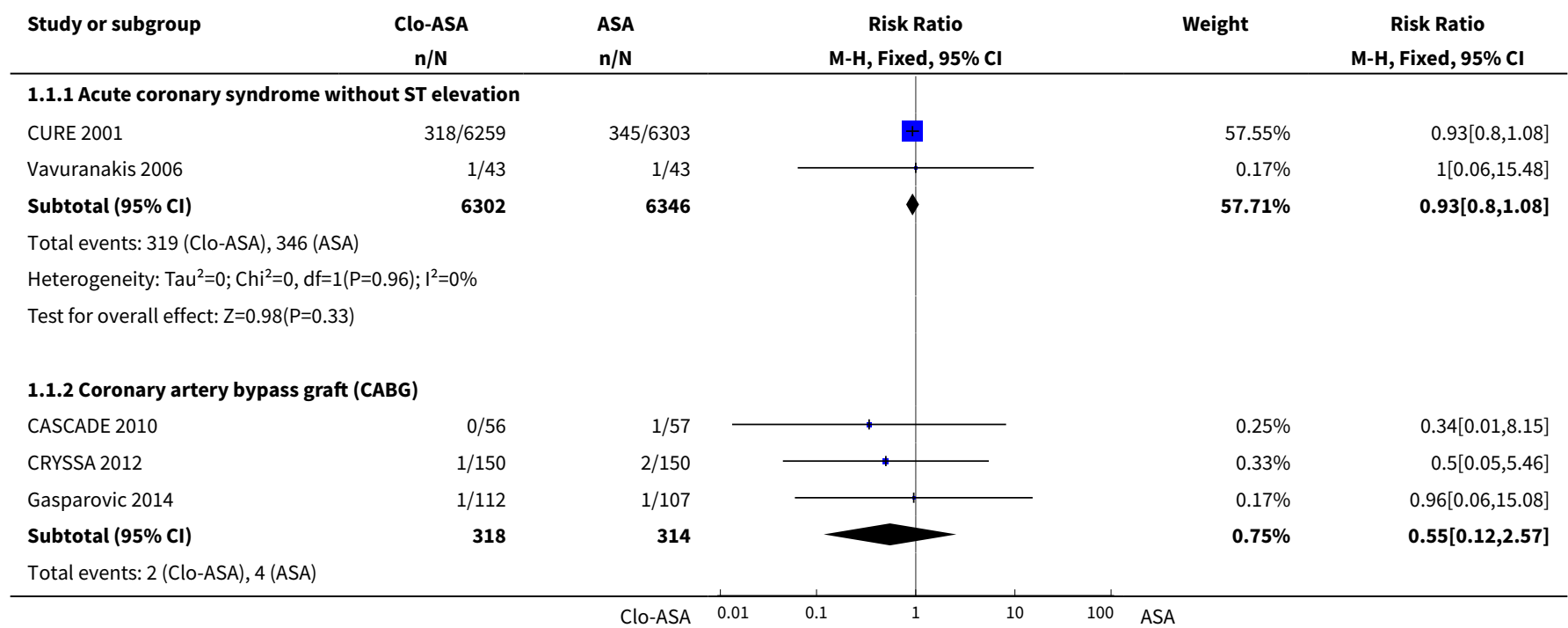




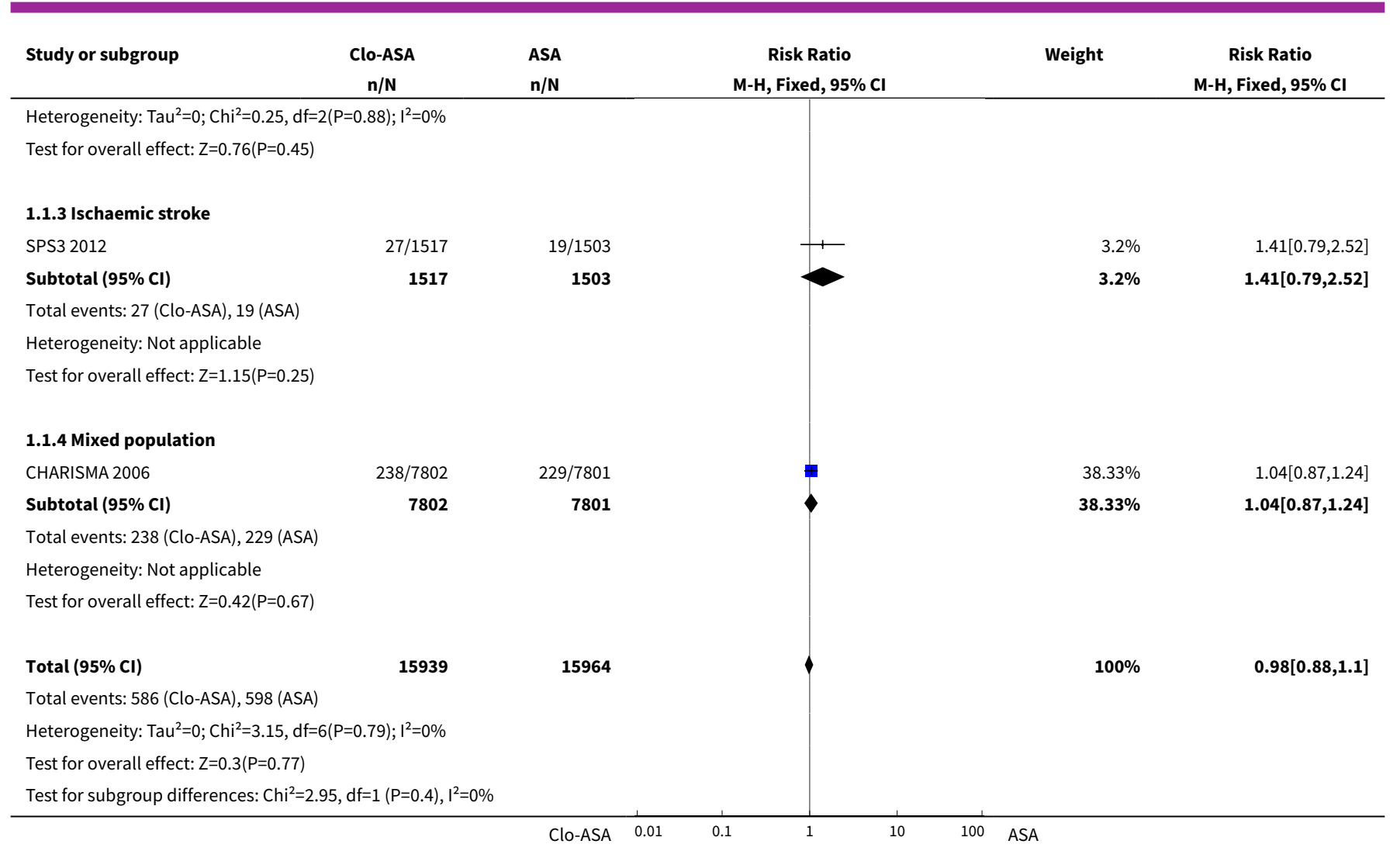

Analysis 1.2. Comparison 1 Clopidogrel (Clo) plus aspirin (ASA) versus aspirin alone, Outcome 2 All-cause mortality.

\begin{tabular}{|c|c|c|c|c|c|}
\hline Study or subgroup & $\begin{array}{c}\text { Clo-ASA } \\
\mathrm{n} / \mathrm{N}\end{array}$ & $\begin{array}{l}\text { ASA } \\
\mathrm{n} / \mathrm{N}\end{array}$ & $\begin{array}{c}\text { Risk Ratio } \\
\text { M-H, Random, } 95 \% \mathrm{CI}\end{array}$ & \multirow[t]{2}{*}{ Weight } & \multirow[t]{2}{*}{$\begin{array}{c}\text { Risk Ratio } \\
\text { M-H, Random, } 95 \% \mathrm{Cl} \\
\end{array}$} \\
\hline \multicolumn{3}{|c|}{ 1.2.1 Acute coronary syndrome without ST elevation } & & & \\
\hline CURE 2001 & $359 / 6259$ & $390 / 6303$ & m & $34.48 \%$ & $0.93[0.81,1.07]$ \\
\hline Subtotal $(95 \% \mathrm{Cl})$ & 6259 & 6303 & 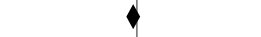 & $34.48 \%$ & $0.93[0.81,1.07]$ \\
\hline \multicolumn{6}{|c|}{ Total events: 359 (Clo-ASA), 390 (ASA) } \\
\hline \multicolumn{6}{|c|}{ Heterogeneity: $\operatorname{Tau}^{2}=0 ; \mathrm{Chi}^{2}=0, \mathrm{df}=0(\mathrm{P}<0.0001) ; \mathrm{I}^{2}=100 \%$} \\
\hline \multicolumn{6}{|c|}{ Test for overall effect: $Z=1.07(P=0.29)$} \\
\hline \multicolumn{6}{|c|}{ 1.2.2 Ischaemic stroke } \\
\hline SPS3 2012 & $113 / 1517$ & $77 / 1503$ & - & $20.97 \%$ & $1.45[1.1,1.93]$ \\
\hline Subtotal $(95 \% \mathrm{Cl})$ & 1517 & 1503 & $\bullet$ & $20.97 \%$ & $1.45[1.1,1.93]$ \\
\hline \multicolumn{6}{|c|}{ Total events: 113 (Clo-ASA), 77 (ASA) } \\
\hline \multicolumn{6}{|c|}{ Heterogeneity: Not applicable } \\
\hline \multicolumn{6}{|c|}{ Test for overall effect: $\mathrm{Z}=2.61(\mathrm{P}=0.01)$} \\
\hline \multicolumn{6}{|l|}{ 1.2.3 CABG } \\
\hline CASCADE 2010 & $0 / 56$ & $1 / 57$ & & $0.31 \%$ & $0.34[0.01,8.15]$ \\
\hline CRYSSA 2012 & $1 / 150$ & 2/150 & . & $0.55 \%$ & $0.5[0.05,5.46]$ \\
\hline Gasparovic 2014 & 2/112 & $4 / 107$ & - & $1.1 \%$ & $0.48[0.09,2.55]$ \\
\hline TEG-CABG & $1 / 79$ & $5 / 81$ & - & $0.69 \%$ & $0.21[0.02,1.72]$ \\
\hline Subtotal $(95 \% \mathrm{Cl})$ & 397 & 395 & & $2.66 \%$ & $0.37[0.13,1.1]$ \\
\hline \multicolumn{6}{|c|}{ Total events: 4 (Clo-ASA), 12 (ASA) } \\
\hline & & Clo-ASA & 0.1 & & \\
\hline
\end{tabular}




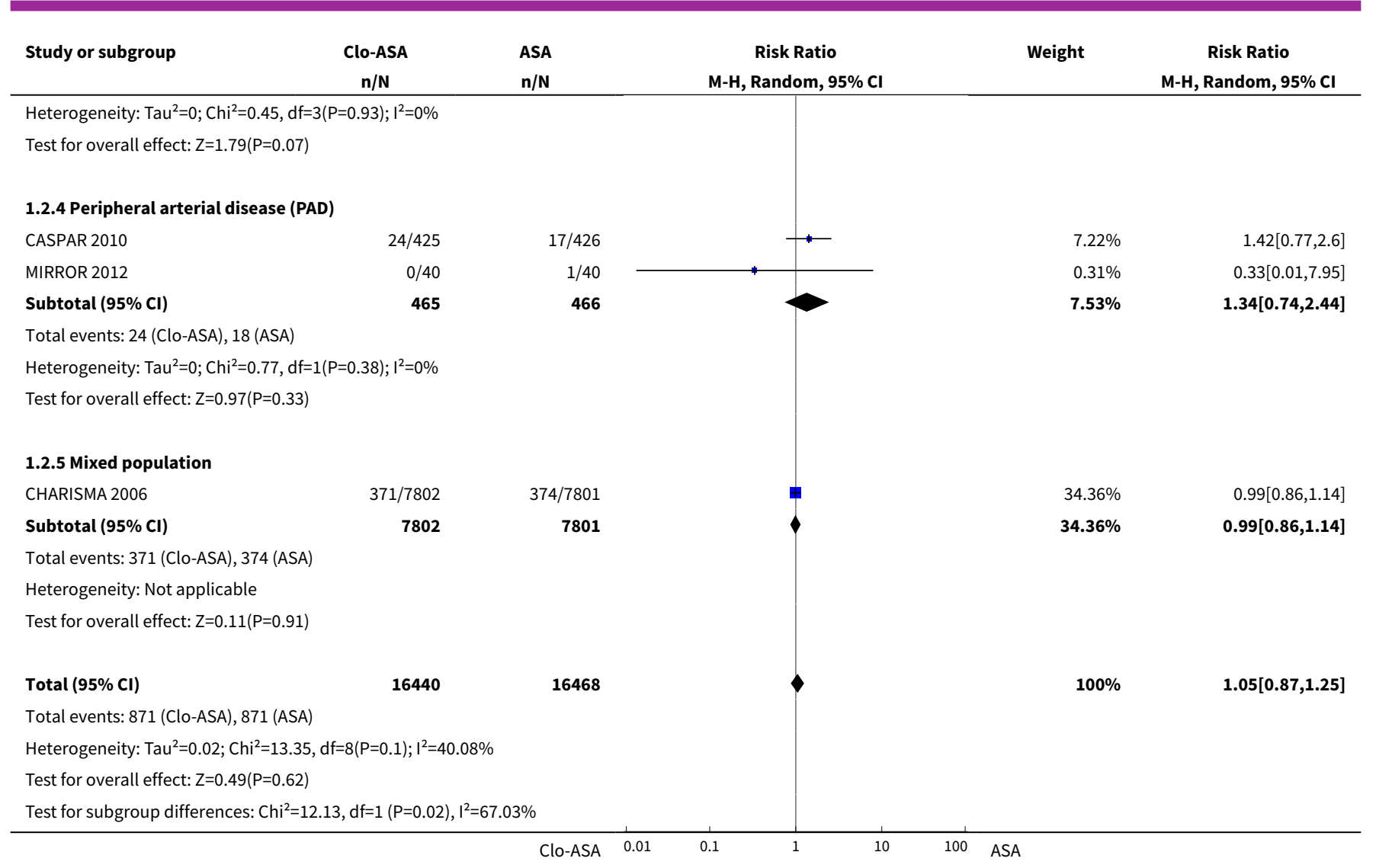

\section{Analysis 1.3. Comparison 1 Clopidogrel (Clo) plus aspirin (ASA) versus} aspirin alone, Outcome $3 \mathrm{Fatal}$ and non-fatal myocardial infarction.

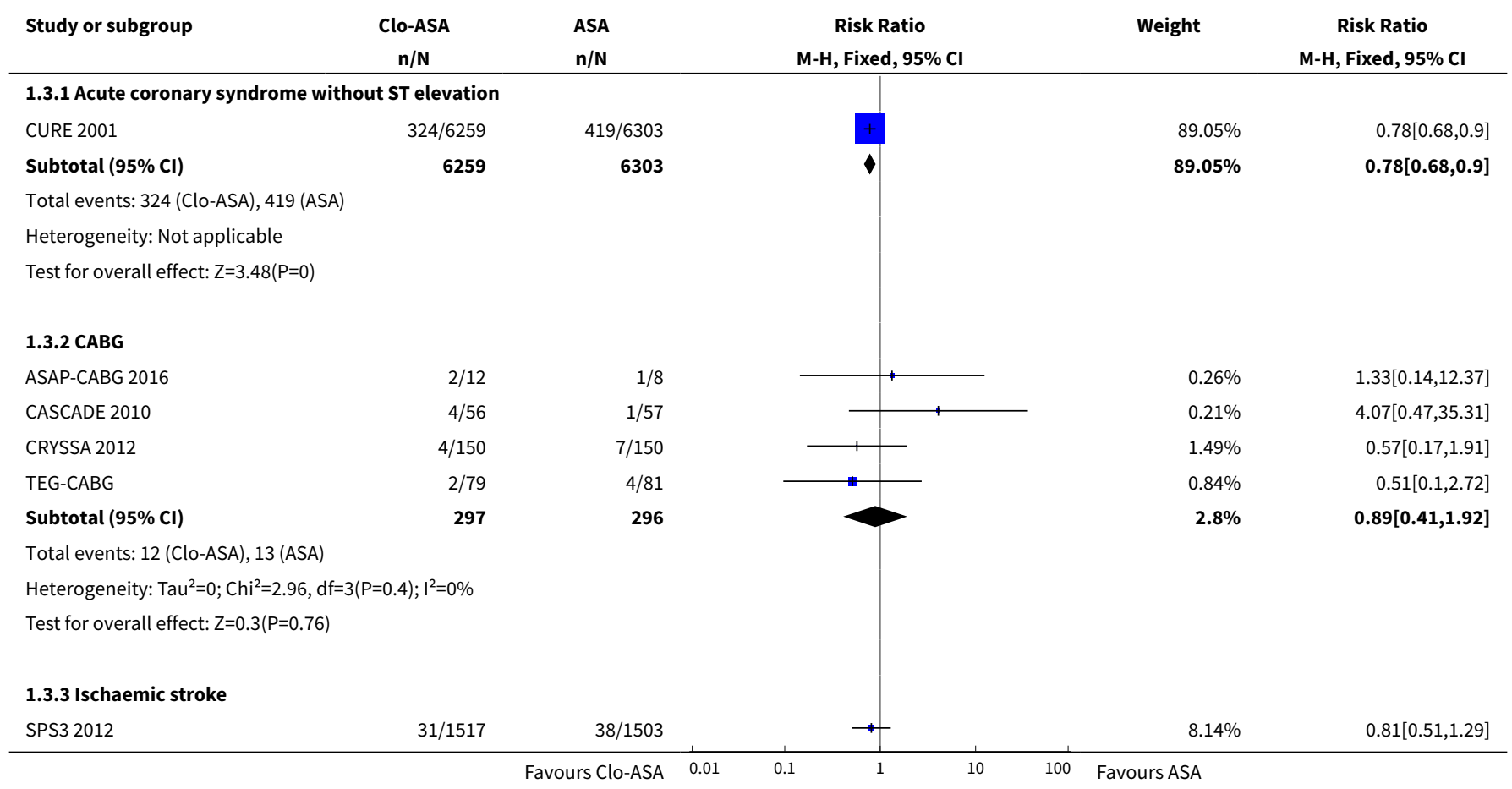




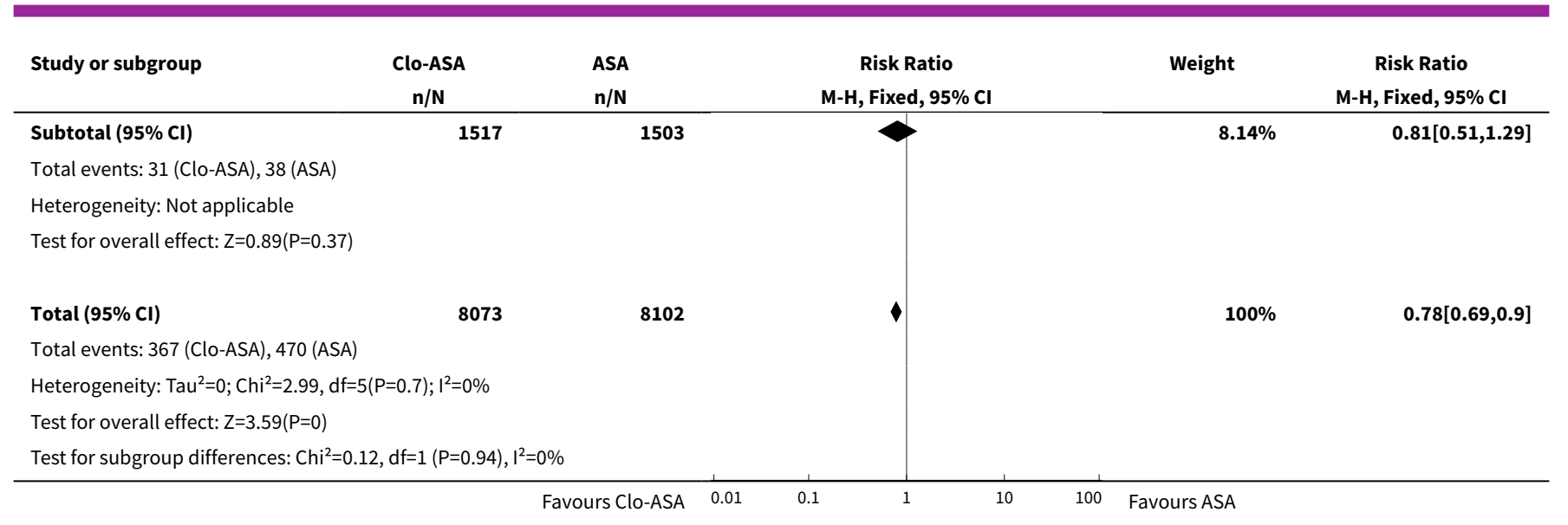

Analysis 1.4. Comparison 1 Clopidogrel (Clo) plus aspirin (ASA) versus aspirin alone, Outcome $4 \mathrm{Fatal}$ and non-fatal ischaemic stroke.

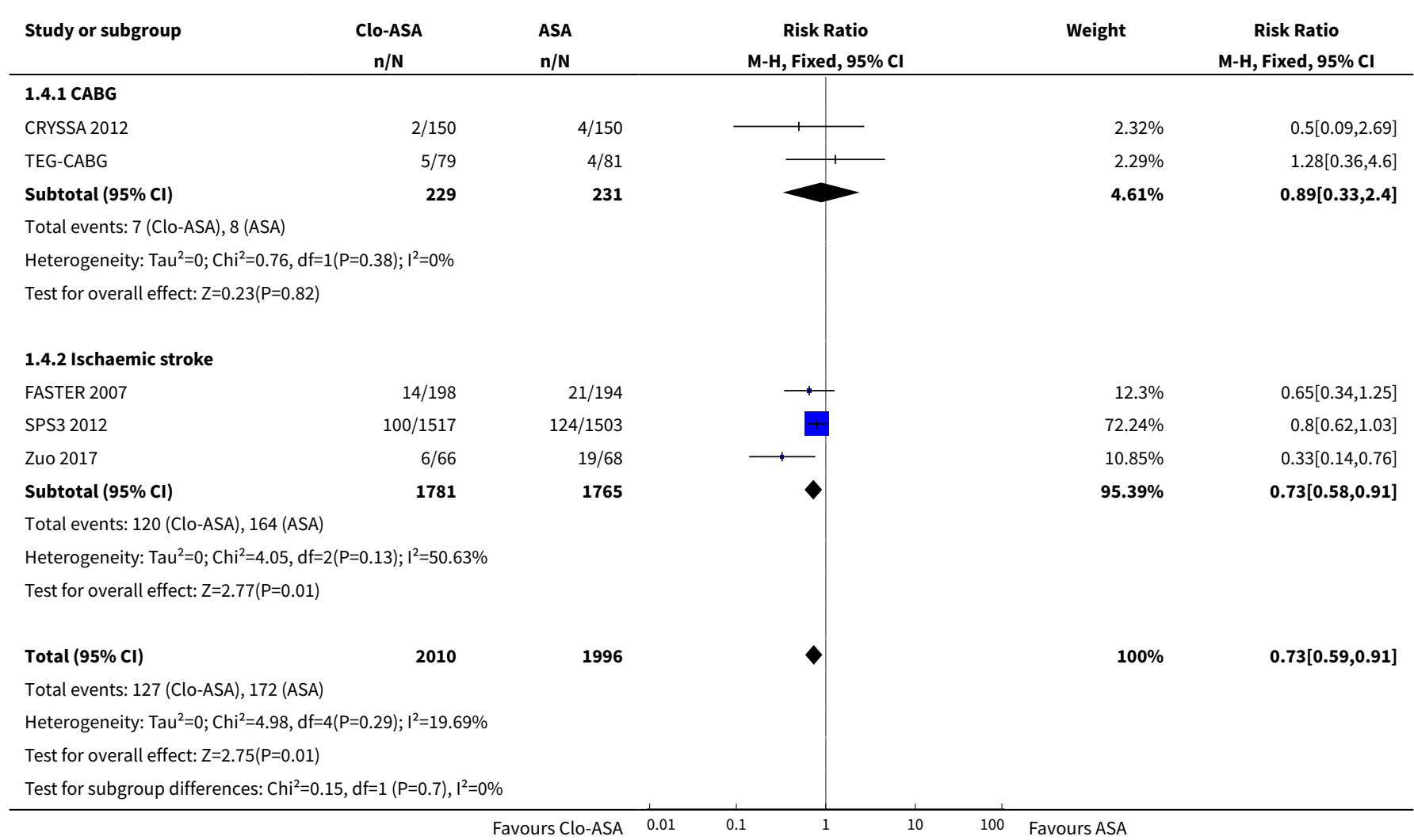

\section{Analysis 1.5. Comparison 1 Clopidogrel (Clo) plus aspirin (ASA) versus aspirin alone, Outcome 5 Major bleeding.}

\begin{tabular}{|c|c|c|c|c|c|c|}
\hline Study or subgroup & \multirow[t]{2}{*}{$\begin{array}{c}\text { Clo-ASA } \\
\mathbf{n} / \mathbf{N}\end{array}$} & \multirow[t]{2}{*}{$\begin{array}{l}\text { ASA } \\
n / N\end{array}$} & & $\begin{array}{l}\text { k Ratio } \\
\text { red, } 95 \% \mathrm{Cl}\end{array}$ & Weight & \multirow[t]{2}{*}{$\begin{array}{c}\text { Risk Ratio } \\
\text { M-H, Fixed, } 95 \% \text { CI }\end{array}$} \\
\hline \multicolumn{4}{|c|}{ 1.5.1 Acute coronary syndrome } & & & \\
\hline
\end{tabular}




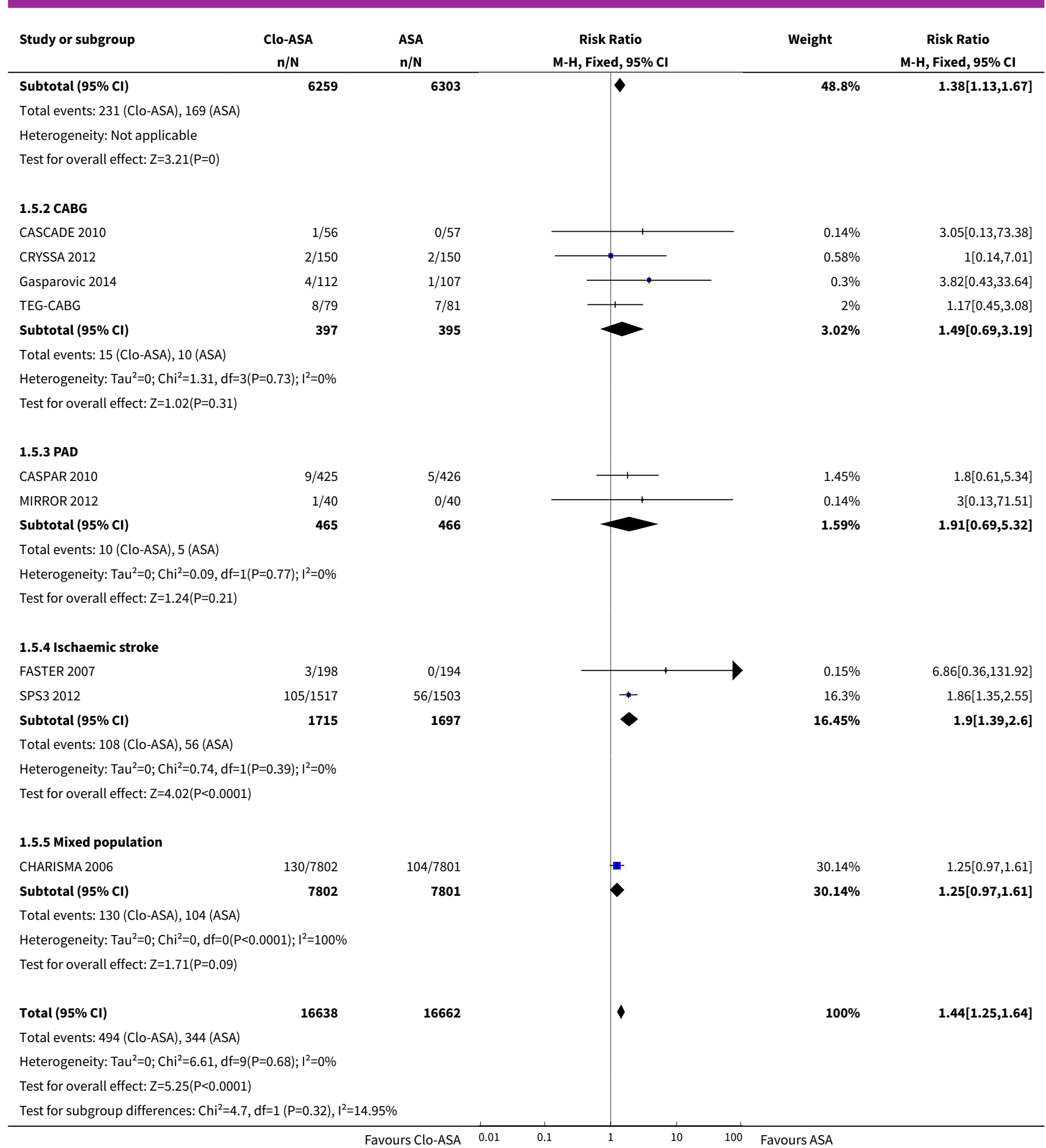


Analysis 1.6. Comparison 1 Clopidogrel (Clo) plus aspirin (ASA) versus aspirin alone, Outcome 6 Minor bleeding.

Study or subgroup

1.6.1 Acute coronary syndrome

CURE 2001

Subtotal $(95 \% \mathrm{CI})$

Clo-ASA

$\mathbf{n} / \mathbf{N}$

ASA

Risk Ratio

M-H, Fixed, $95 \% \mathrm{Cl}$

322/6259 156/6303

6259

6303

Total events: 322 (Clo-ASA), 156 (ASA)

Heterogeneity: Not applicable

Test for overall effect: $Z=7.63(P<0.0001)$

\subsubsection{CABG}

CASCADE 2010

CRYSSA 2012

Gasparovic 2014

TEG-CABG

Subtotal $(95 \% \mathrm{CI})$

$3 / 56$

$2 / 150$

$24 / 112$

$24 / 79$

397

Total events: 53 (Clo-ASA), 34 (ASA)

Heterogeneity: $\operatorname{Tau}^{2}=0 ; \mathrm{Chi}^{2}=3.13, \mathrm{df}=3(\mathrm{P}=0.37) ; \mathrm{I}^{2}=4.01 \%$

Test for overall effect: $Z=2.16(P=0.03)$

1.6.3 PAD

CASPAR 2010

Subtotal $(95 \% \mathrm{Cl})$

\section{$46 / 425$}

425

Total events: 46 (Clo-ASA), 21 (ASA)

Heterogeneity: Not applicable

Test for overall effect: $Z=3.09(P=0)$

1.6.4 Ischaemic stroke

FASTER 2007

Zuo 2017

Subtotal $(95 \% \mathrm{Cl})$

Total events: 63 (Clo-ASA), 27 (ASA)

Heterogeneity: $\mathrm{Tau}^{2}=0 ; \mathrm{Chi}^{2}=0.3, \mathrm{df}=1(\mathrm{P}=0.59) ; \mathrm{I}^{2}=0 \%$

Test for overall effect: $Z=3.97(P<0.0001)$

Total $(95 \% \mathrm{CI})$

7345

Total events: 484 (Clo-ASA), 238 (ASA)

Heterogeneity: $\mathrm{Tau}^{2}=0 ; \mathrm{Chi}^{2}=5.84, \mathrm{df}=7(\mathrm{P}=0.56) ; \mathrm{I}^{2}=0 \%$

Test for overall effect: $Z=9.32(P<0.0001)$

Test for subgroup differences: $\mathrm{Chi}^{2}=2.35, \mathrm{df}=1(\mathrm{P}=0.5), \mathrm{I}^{2}=0 \%$

\section{$3 / 57$}

$2 / 150$

$19 / 107$

$10 / 81$

395

$21 / 426$

426

7386
$8.8 \%$

$8.8 \%$

$11.44 \%$

$0.21 \%$

$11.64 \%$

$100 \%$

$2.03[1.75,2.36]$
$1.02[0.21,4.83]$

$1[0.14,7.01]$

$1.21[0.7,2.07]$

$2.46[1.26,4.81]$

$1.54[1.04,2.28]$
2.2[1.33,3.61]

2.2[1.33,3.61]

2.21[1.47,3.33]

5.15[0.25,105.27]

$2.27[1.51,3.39]$
$2.08[1.72,2.51]$
Risk Ratio M-H, Fixed, $95 \% \mathrm{Cl}$ $0.51[0.05,5.45]$

$0.5[0.05,5.46]$

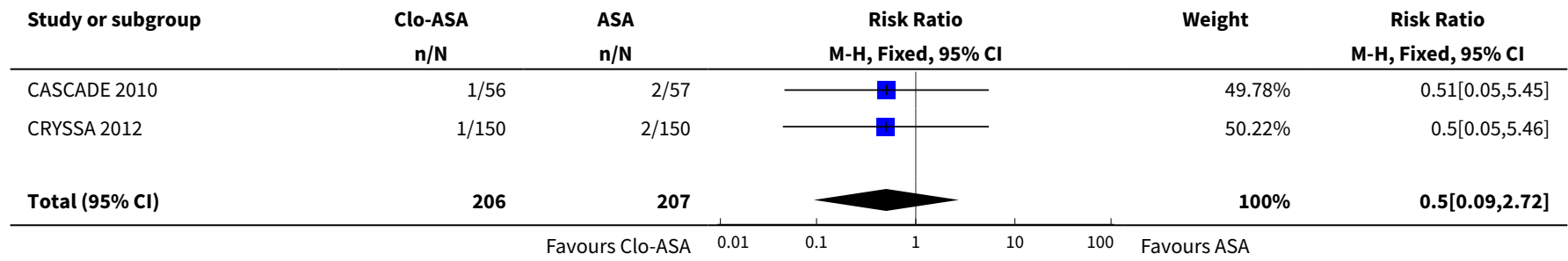




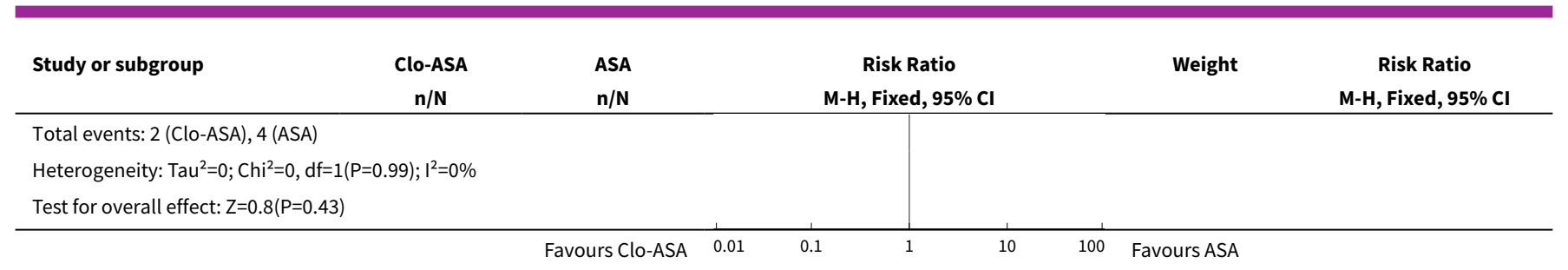

Analysis 1.8. Comparison 1 Clopidogrel (Clo) plus aspirin (ASA) versus aspirin alone, Outcome 8 Saphenous vein graft patency for CABG.

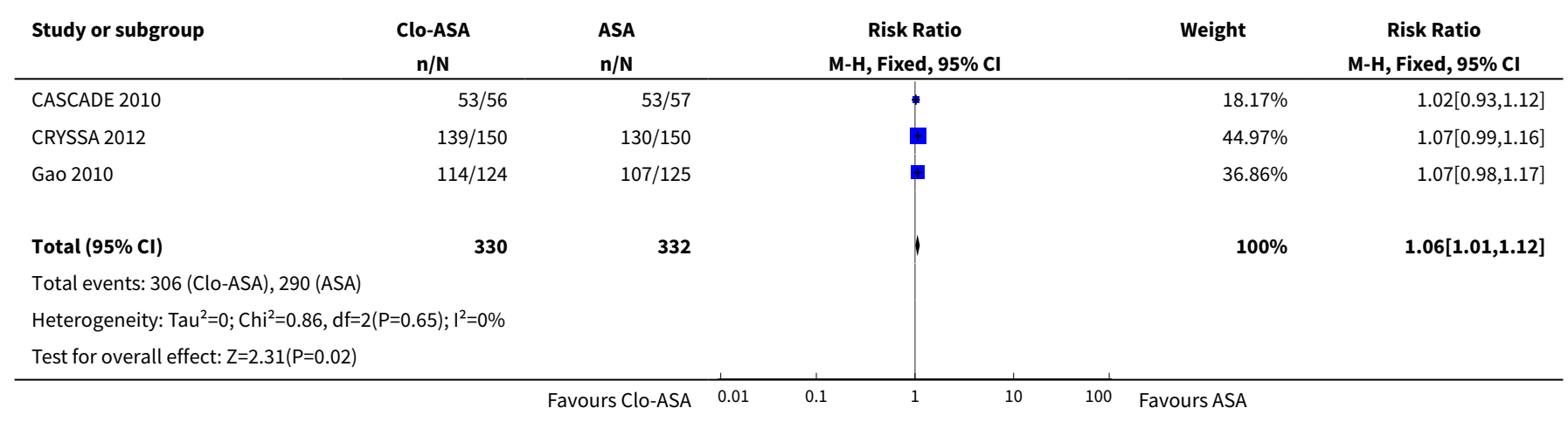

Analysis 1.9. Comparison 1 Clopidogrel (Clo) plus aspirin (ASA) versus aspirin alone, Outcome 9 Amputation for people with PAD.

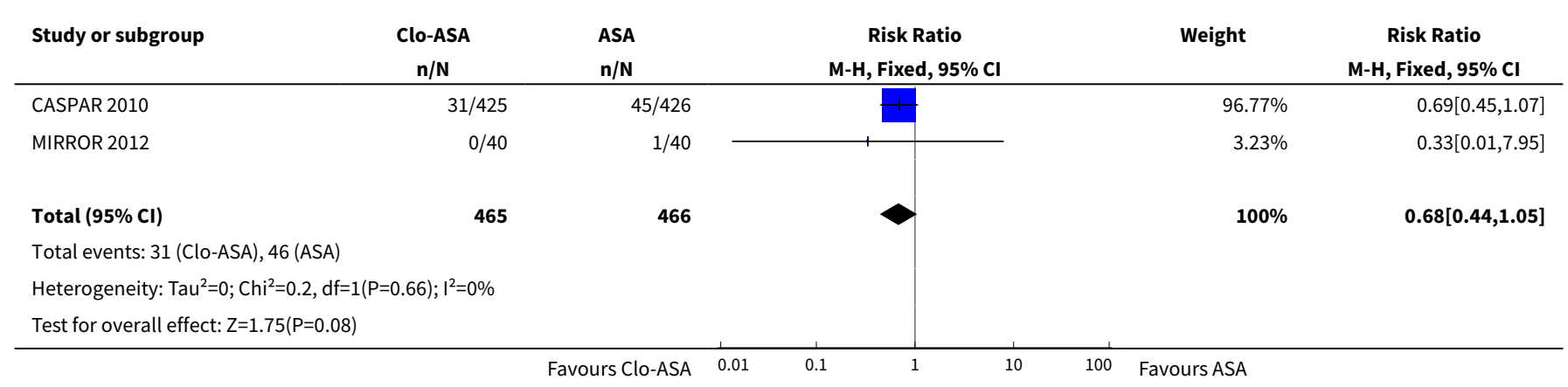

Analysis 1.10. Comparison 1 Clopidogrel (Clo) plus aspirin (ASA) versus aspirin alone, Outcome 10 Sensitivity analysis - random-effects model: cardiovascular mortality.

\begin{tabular}{|c|c|c|c|c|c|}
\hline Study or subgroup & $\begin{array}{c}\text { Clo-ASA } \\
n / N\end{array}$ & $\begin{array}{l}\text { ASA } \\
n / N\end{array}$ & $\begin{array}{c}\text { Risk Ratio } \\
\text { M-H, Random, } 95 \% \mathrm{Cl} \\
\end{array}$ & Weight & \multirow[t]{2}{*}{$\begin{array}{c}\text { Risk Ratio } \\
\text { M-H, Random, } 95 \% \mathrm{Cl} \\
\end{array}$} \\
\hline \multicolumn{5}{|c|}{ 1.10.1 Acute coronary syndrome without ST elevation } & \\
\hline CURE 2001 & $318 / 6259$ & $345 / 6303$ & & $56.65 \%$ & $0.93[0.8,1.08]$ \\
\hline Vavuranakis 2006 & $1 / 43$ & $1 / 43$ & & $0.17 \%$ & $1[0.06,15.48]$ \\
\hline Subtotal $(95 \% \mathrm{CI})$ & 6302 & 6346 & $\uparrow$ & $56.81 \%$ & $0.93[0.8,1.08]$ \\
\hline \multicolumn{6}{|c|}{ Total events: 319 (Clo-ASA), 346 (ASA) } \\
\hline & & Clo-ASA 0.01 & 0.1 & 100 ASA & \\
\hline
\end{tabular}




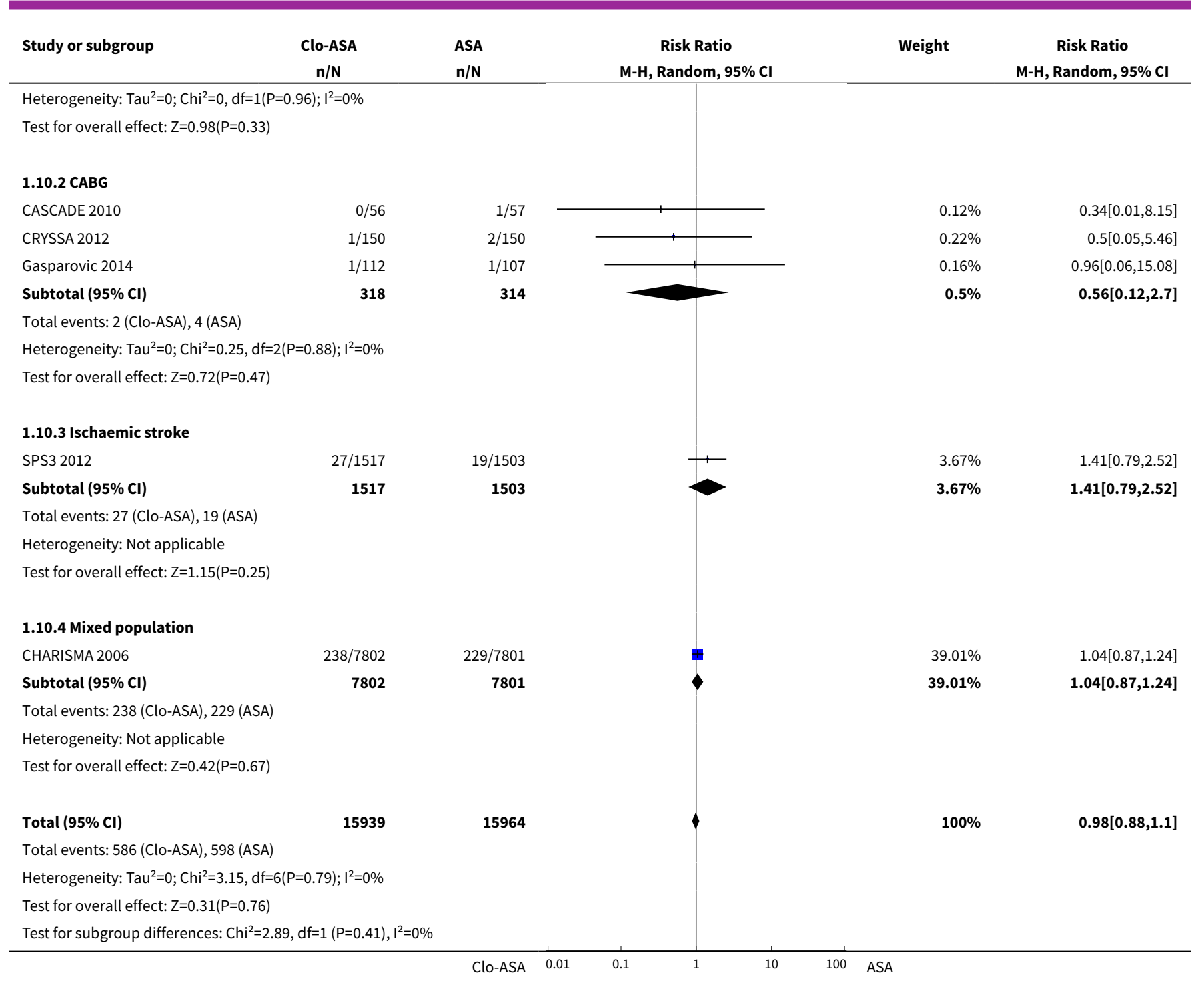

\section{Analysis 1.11. Comparison 1 Clopidogrel (Clo) plus aspirin (ASA) versus aspirin alone, Outcome 11 Sensitivity analysis - random-effects model: fatal and non-fatal myocardial infarction.}

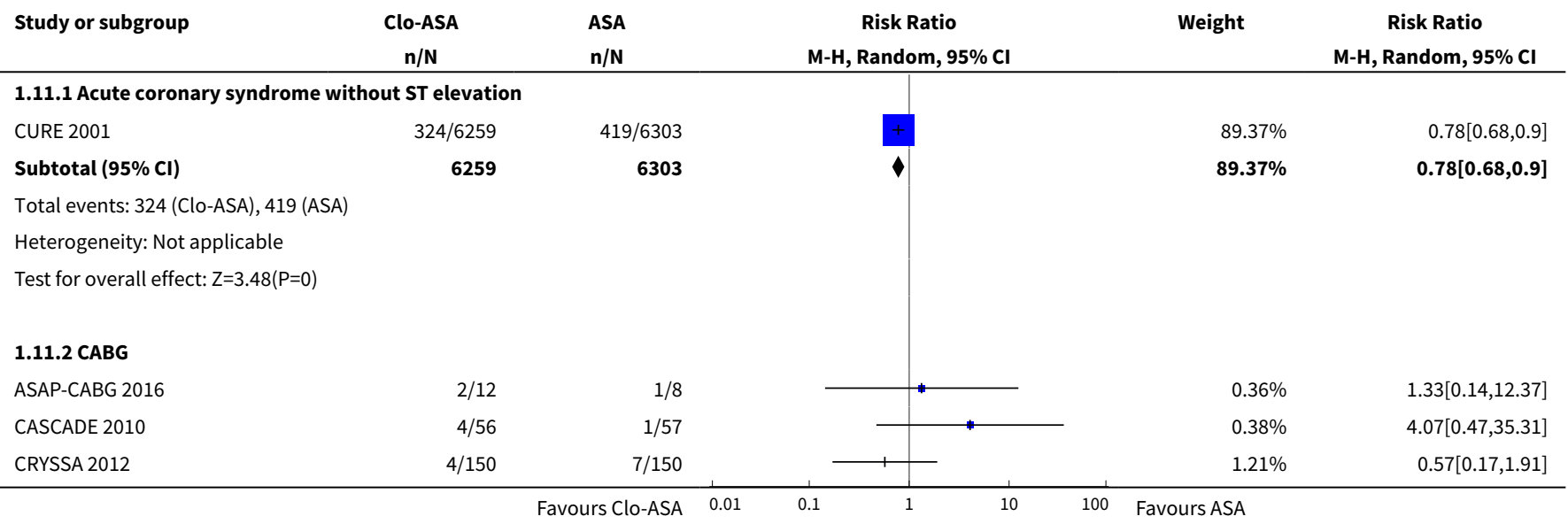




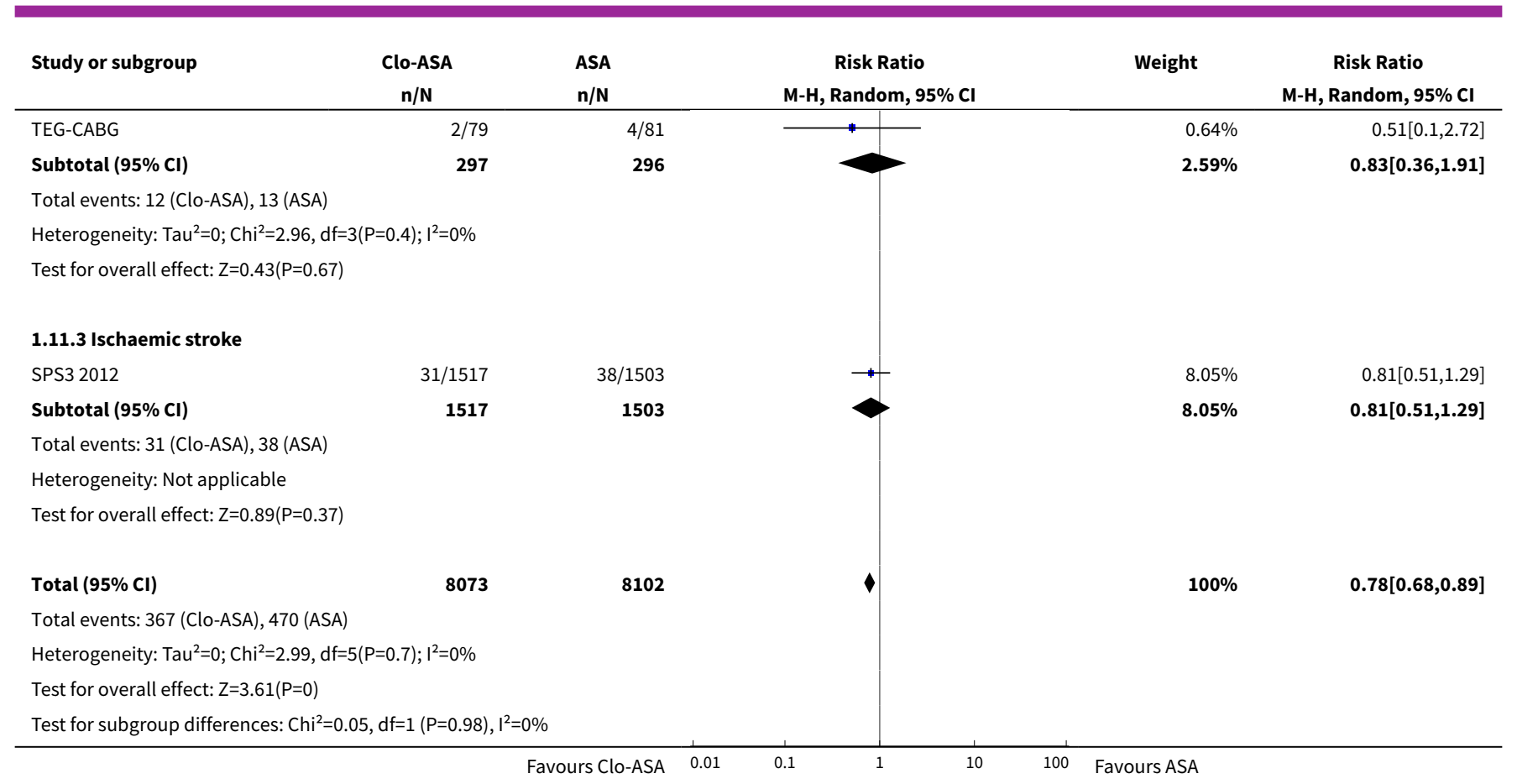

Analysis 1.12. Comparison 1 Clopidogrel (Clo) plus aspirin (ASA) versus aspirin alone, Outcome 12 Sensitivity analysis - random-effects model: fatal and non-fatal ischaemic stroke.

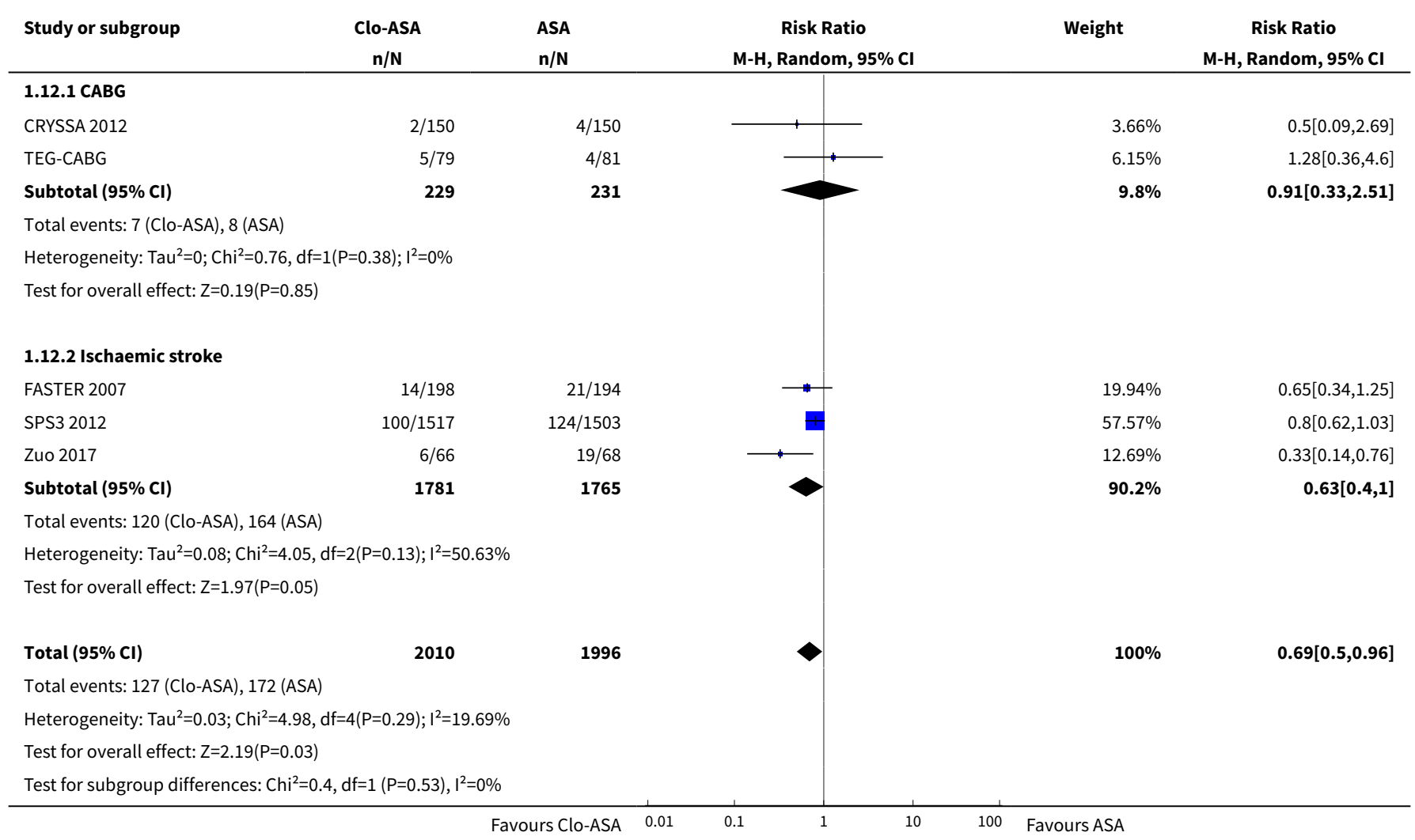


Analysis 1.13. Comparison 1 Clopidogrel (Clo) plus aspirin (ASA) versus aspirin alone, Outcome 13 Sensitivity analysis - random-effects model: major bleeding.

\begin{tabular}{|c|c|c|c|c|c|}
\hline Study or subgroup & $\begin{array}{c}\text { Clo-ASA } \\
\mathrm{n} / \mathrm{N}\end{array}$ & $\begin{array}{l}\text { ASA } \\
n / N\end{array}$ & $\begin{array}{c}\text { Risk Ratio } \\
\text { M-H, Random, 95\% Cl }\end{array}$ & Weight & $\begin{array}{c}\text { Risk Ratio } \\
\text { M-H, Random, } 95 \% \mathrm{CI}\end{array}$ \\
\hline \multicolumn{3}{|c|}{ 1.13.1 Acute coronary syndrome without ST elevation } & & & \\
\hline CURE 2001 & $231 / 6259$ & $169 / 6303$ & + & $48.39 \%$ & $1.38[1.13,1.67]$ \\
\hline Subtotal $(95 \% \mathrm{Cl})$ & 6259 & 6303 & 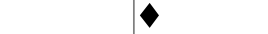 & $48.39 \%$ & $1.38[1.13,1.67]$ \\
\hline \multicolumn{6}{|c|}{ Total events: 231 (Clo-ASA), 169 (ASA) } \\
\hline \multicolumn{6}{|c|}{ Heterogeneity: Not applicable } \\
\hline \multicolumn{6}{|c|}{ Test for overall effect: $Z=3.21(P=0)$} \\
\hline \multicolumn{6}{|l|}{ 1.13.2 CABG } \\
\hline CASCADE 2010 & $1 / 56$ & $0 / 57$ & & $0.18 \%$ & $3.05[0.13,73.38]$ \\
\hline CRYSSA 2012 & $2 / 150$ & $2 / 150$ & & $0.49 \%$ & $1[0.14,7.01]$ \\
\hline Gasparovic 2014 & $4 / 112$ & $1 / 107$ & 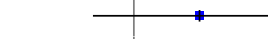 & $0.39 \%$ & $3.82[0.43,33.64]$ \\
\hline TEG-CABG & $8 / 79$ & $7 / 81$ & & $1.98 \%$ & $1.17[0.45,3.08]$ \\
\hline \multicolumn{6}{|c|}{ Total events: 15 (Clo-ASA), 10 (ASA) } \\
\hline \multicolumn{6}{|c|}{ Heterogeneity: Tau $^{2}=0 ; \mathrm{Chi}^{2}=1.31, \mathrm{df}=3(\mathrm{P}=0.73) ; \mathrm{I}^{2}=0 \%$} \\
\hline \multicolumn{6}{|c|}{ Test for overall effect: $Z=0.86(P=0.39)$} \\
\hline \multicolumn{6}{|l|}{ 1.13.3 PAD } \\
\hline CASPAR 2010 & $9 / 425$ & $5 / 426$ & - & $1.57 \%$ & $1.8[0.61,5.34]$ \\
\hline MIRROR 2012 & $1 / 40$ & $0 / 40$ & & $0.18 \%$ & $3[0.13,71.51]$ \\
\hline Subtotal $(95 \% \mathrm{CI})$ & 465 & 466 & & $1.75 \%$ & $1.9[0.68,5.31]$ \\
\hline \multicolumn{6}{|c|}{ Total events: 10 (Clo-ASA), 5 (ASA) } \\
\hline \multicolumn{6}{|c|}{ Heterogeneity: $\mathrm{Tau}^{2}=0 ; \mathrm{Chi}^{2}=0.09, \mathrm{df}=1(\mathrm{P}=0.77) ; \mathrm{I}^{2}=0 \%$} \\
\hline \multicolumn{6}{|c|}{ Test for overall effect: $Z=1.23(P=0.22)$} \\
\hline \multicolumn{6}{|c|}{ 1.13.4 Ischaemic stroke } \\
\hline SPS3 2012 & $105 / 1517$ & $56 / 1503$ & $\rightarrow$ & $18.44 \%$ & $1.86[1.35,2.55]$ \\
\hline Subtotal $(95 \% \mathrm{CI})$ & 1715 & 1697 & $\gamma$ & $18.65 \%$ & $1.89[1.38,2.58]$ \\
\hline \multicolumn{6}{|c|}{ Total events: 108 (Clo-ASA), 56 (ASA) } \\
\hline \multicolumn{6}{|c|}{ Heterogeneity: $\operatorname{Tau}^{2}=0 ; \mathrm{Chi}^{2}=0.74, \mathrm{df}=1(\mathrm{P}=0.39) ; \mathrm{I}^{2}=0 \%$} \\
\hline \multicolumn{6}{|c|}{ Test for overall effect: $Z=3.95(P<0.0001)$} \\
\hline \multicolumn{6}{|c|}{ 1.13.5 Mixed population } \\
\hline CHARISMA 2006 & $130 / 7802$ & $104 / 7801$ & - & $28.17 \%$ & $1.25[0.97,1.61]$ \\
\hline Subtotal $(95 \% \mathrm{Cl})$ & 7802 & 7801 & 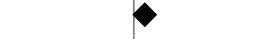 & $28.17 \%$ & $1.25[0.97,1.61]$ \\
\hline \multicolumn{6}{|c|}{ Total events: 130 (Clo-ASA), 104 (ASA) } \\
\hline \multicolumn{6}{|c|}{ Heterogeneity: $\mathrm{Tau}^{2}=0 ; \mathrm{Chi}^{2}=0, \mathrm{df}=0(\mathrm{P}<0.0001) ; \mathrm{I}^{2}=100 \%$} \\
\hline \multicolumn{6}{|c|}{ Test for overall effect: $Z=1.71(P=0.09)$} \\
\hline Total $(95 \% \mathrm{Cl})$ & 16638 & 16662 & $\diamond$ & $100 \%$ & $1.43[1.25,1.64]$ \\
\hline \multicolumn{6}{|c|}{ Total events: 494 (Clo-ASA), 344 (ASA) } \\
\hline \multicolumn{6}{|c|}{ Heterogeneity: Tau $^{2}=0 ; \mathrm{Chi}^{2}=6.61, \mathrm{df}=9(\mathrm{P}=0.68) ; \mathrm{I}^{2}=0 \%$} \\
\hline Test for overall effect & & & & & \\
\hline Test for subgroup dif & $d f=1(P=0.35)$, & & & & \\
\hline
\end{tabular}


Analysis 1.14. Comparison 1 Clopidogrel (Clo) plus aspirin (ASA) versus aspirin alone, Outcome 14 Sensitivity analysis - random-effects model: minor bleeding.

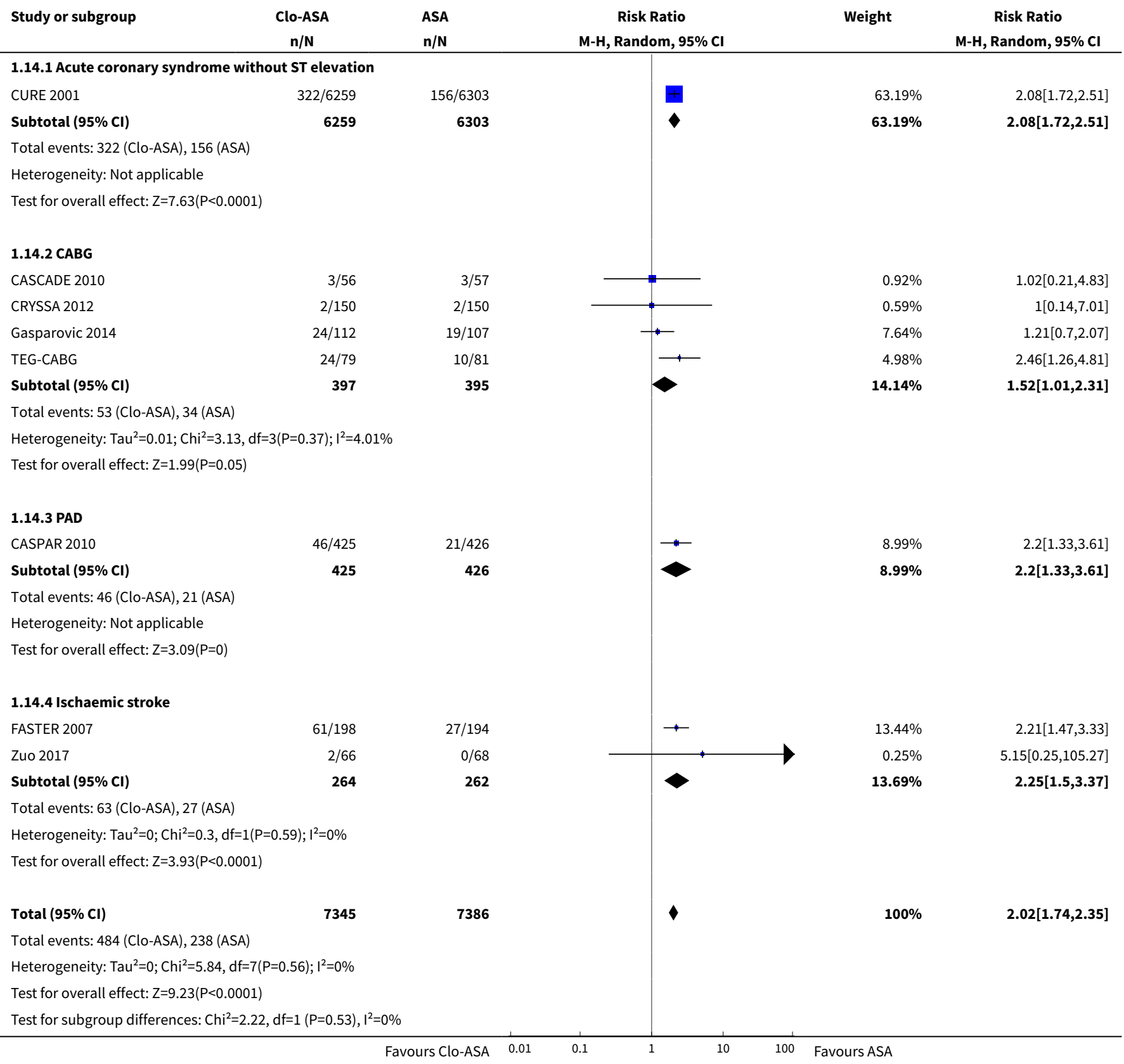

Analysis 1.15. Comparison 1 Clopidogrel (Clo) plus aspirin (ASA) versus aspirin alone, Outcome 15 Sensitivity analysis - random-effects model: repeated revascularization for people with CABG.

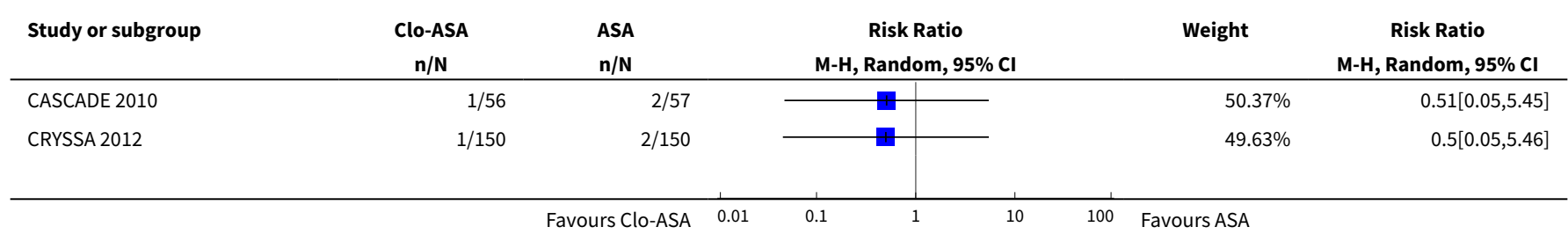




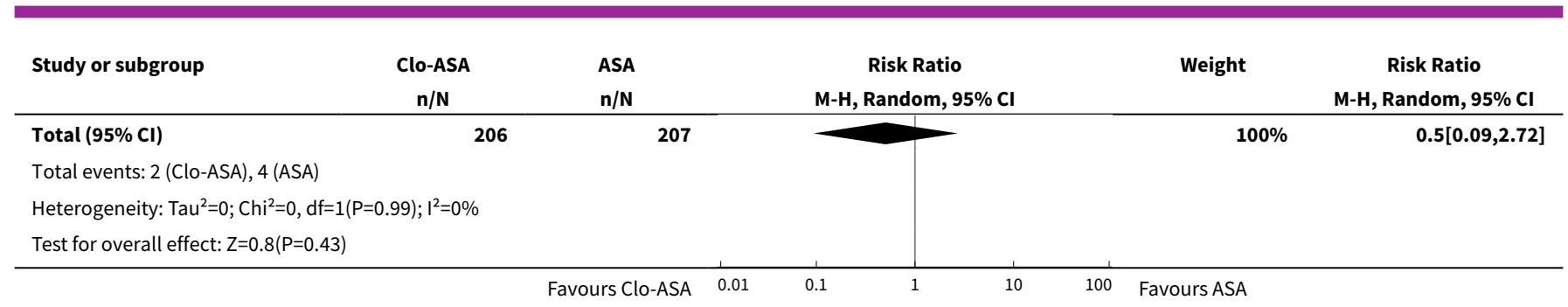

Analysis 1.16. Comparison 1 Clopidogrel (Clo) plus aspirin (ASA) versus aspirin alone, Outcome 16 Sensitivity analysis - random-effects model: SVG patency for people with CABG.

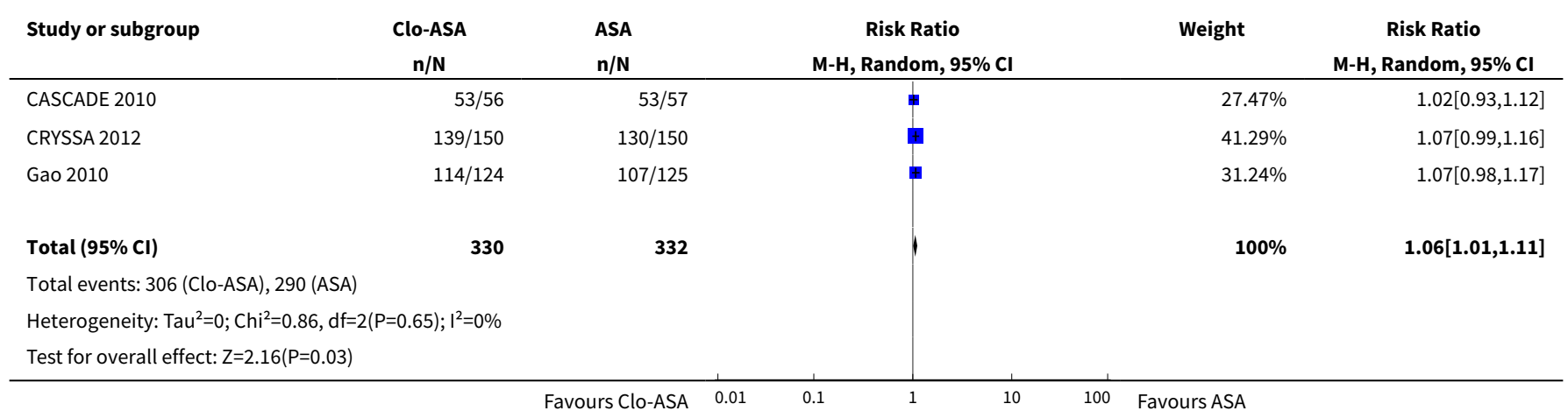

Analysis 1.17. Comparison 1 Clopidogrel (Clo) plus aspirin (ASA) versus aspirin alone, Outcome 17 Sensitivity analysis - random-effects model: amputation for people with PAD.

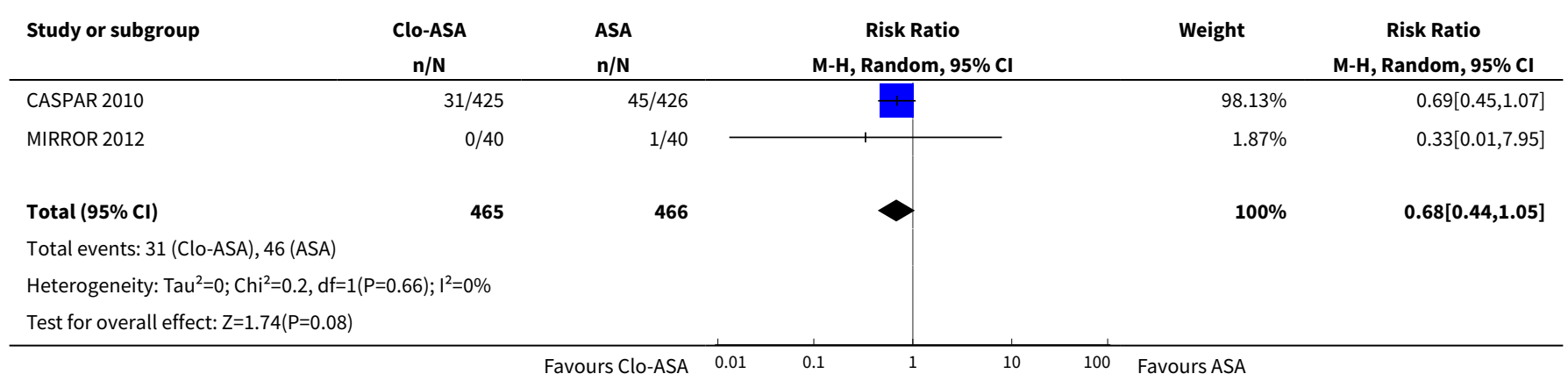

Analysis 1.18. Comparison 1 Clopidogrel (Clo) plus aspirin (ASA) versus aspirin alone, Outcome 18 Sensitivity analysis - low risk of bias (ROB): cardiovascular mortality.

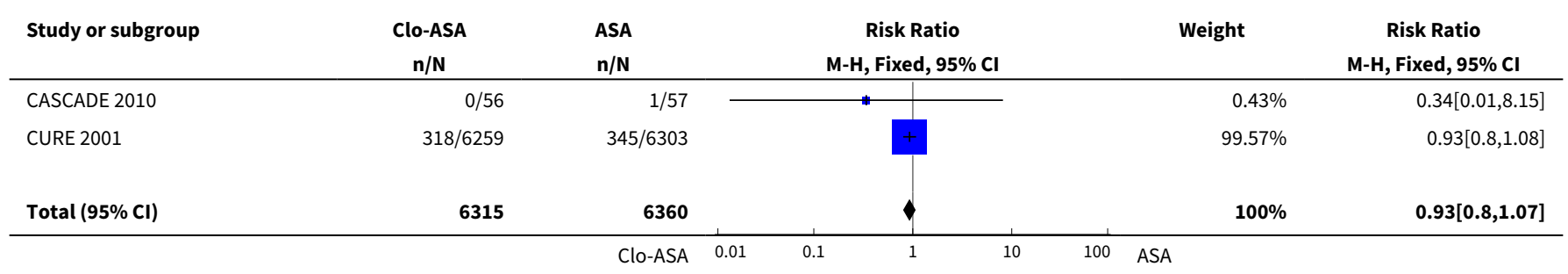




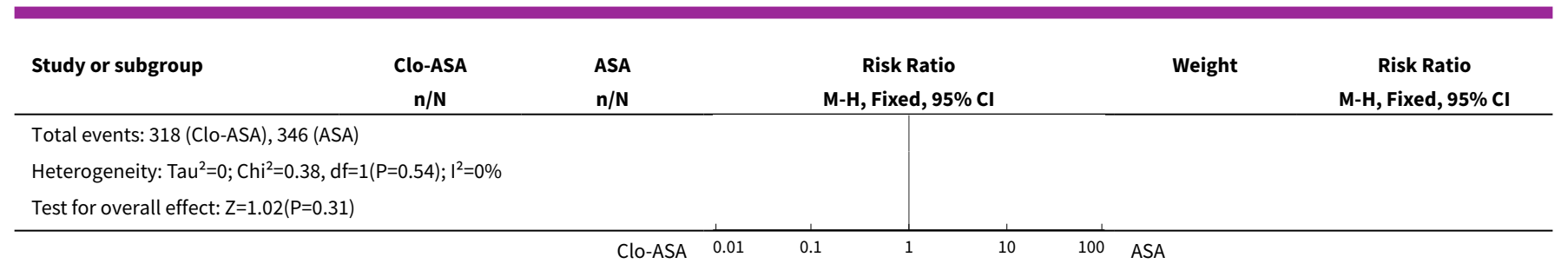

Analysis 1.19. Comparison 1 Clopidogrel (Clo) plus aspirin (ASA) versus aspirin alone, Outcome 19 Sensitivity analysis - low RoB: all-cause mortality.

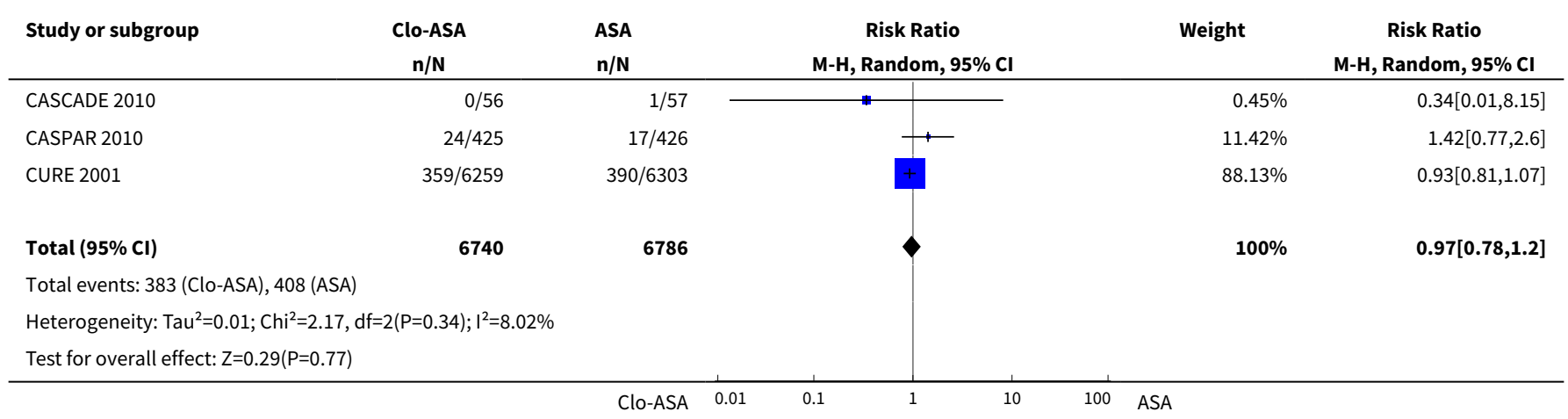

Analysis 1.20. Comparison 1 Clopidogrel (Clo) plus aspirin (ASA) versus aspirin alone, Outcome 20 Sensitivity analysis - low RoB: fatal and non-fatal myocardial infarction.

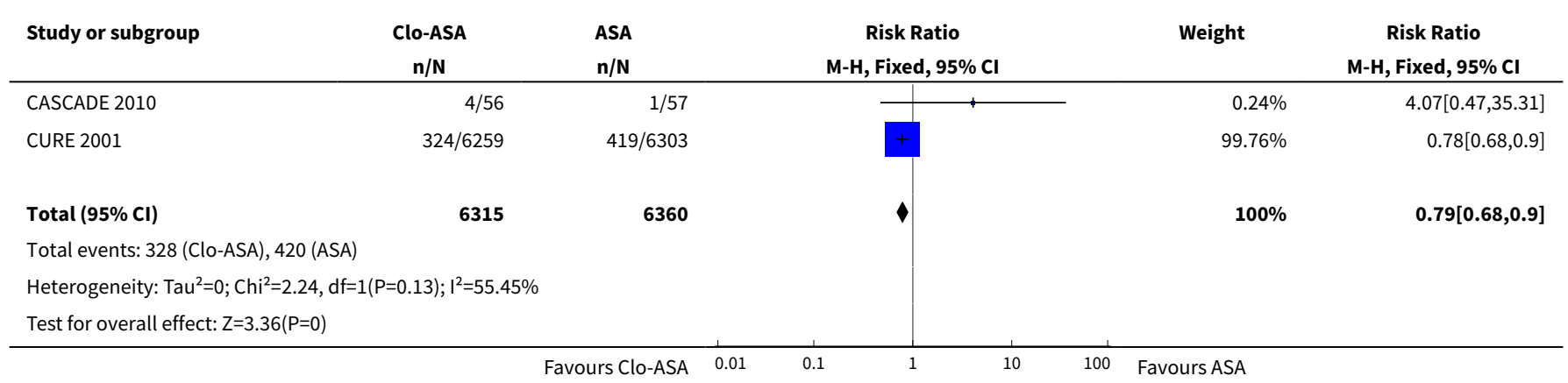

Analysis 1.21. Comparison 1 Clopidogrel (Clo) plus aspirin (ASA) versus aspirin alone, Outcome 21 Sensitivity analysis - low RoB: major bleeding.

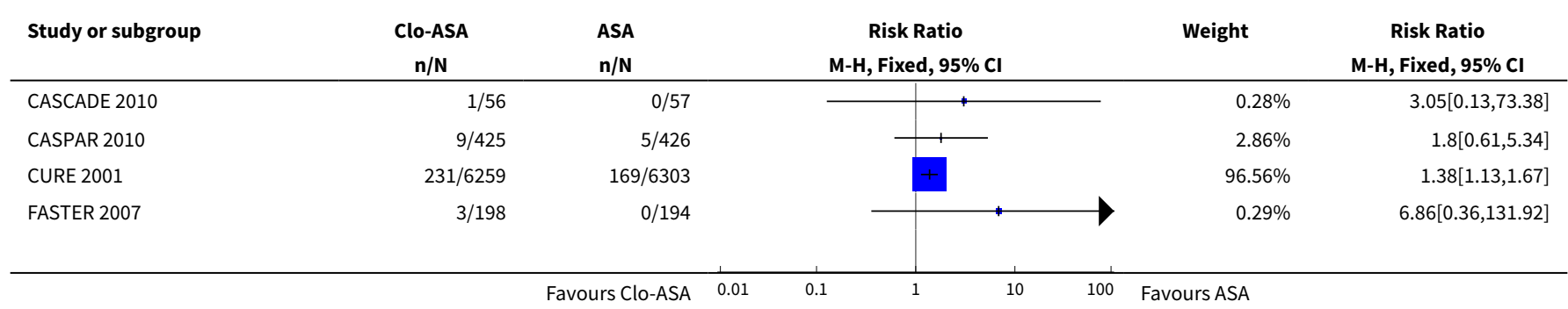




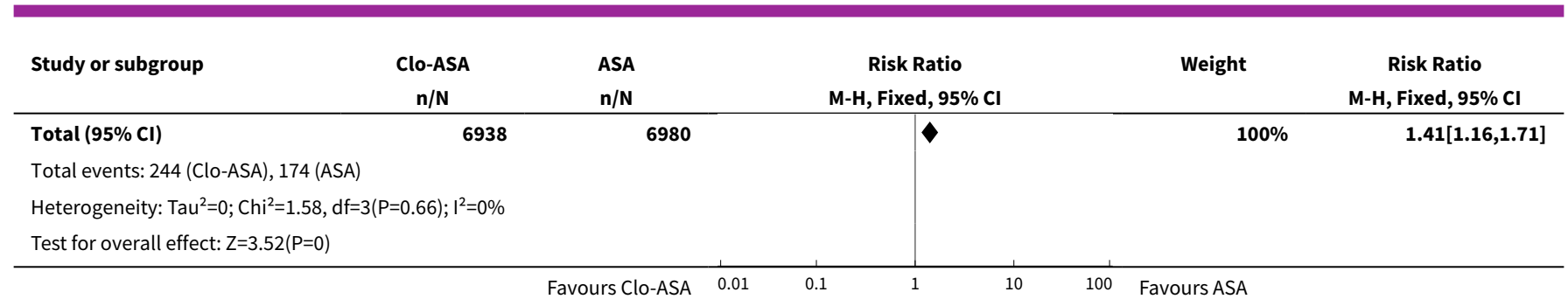

Analysis 1.22. Comparison 1 Clopidogrel (Clo) plus aspirin (ASA) versus aspirin alone, Outcome 22 Sensitivity analysis - low RoB: minor bleeding.

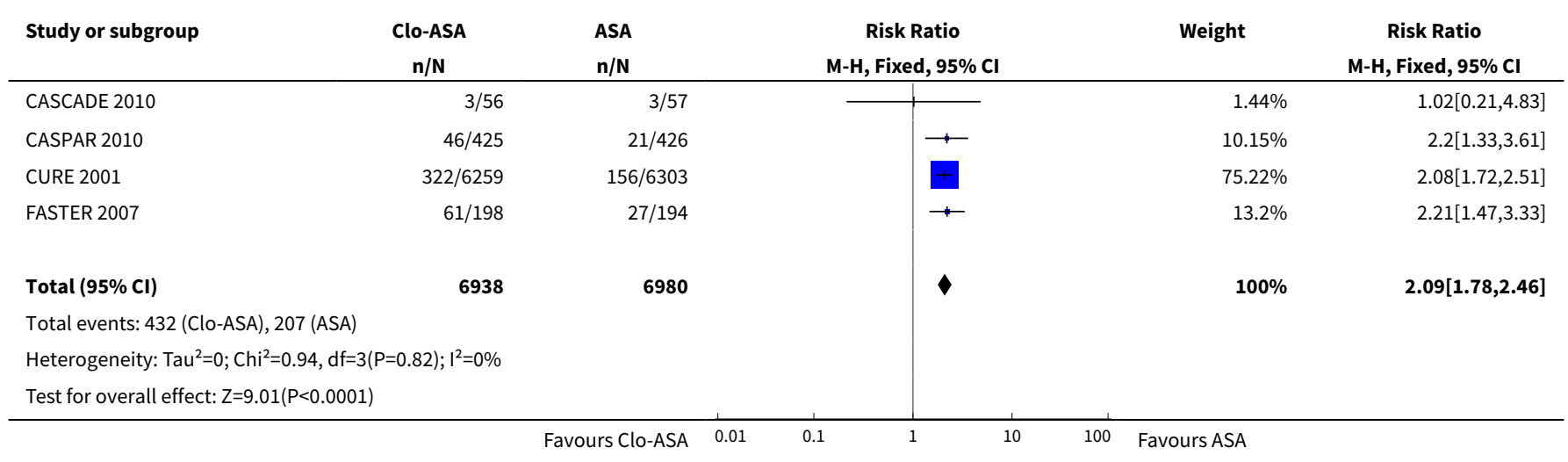

\section{APPENDICES}

\section{Appendix 1. Search strategies 2009}

\section{CENTRAL}

\#1 plavix in All Text

\#2 clopidogrel in All Text

\#3 iscover in All Text

\#4 "pcr 4099" in All Text

\#5 "pcr4099 " in All Text

\#6 "sr 25989" in All Text

\#7 "sr 25990c" in All Text

\#8 "sr25989 " in All Text

\#9 "sr25990c" in All Text

\#10 (\#1 or \#2 or \#3 or \#4 or \#5 or \#6 or \#7 or \#8 or \#9)

$\# 11 \mathrm{MeSH}$ descriptor aspirin this term only

\#12 aspirin in All Text

$\# 13$ acetylsalicylic in All Text

\#14 ASA in All Text

$\# 15$ (\#11 or \#12 or \#13 or \#14)

\#16 (\#10 and \#15)

\section{MEDLINE (Ovid)}

1 clopidogrel.tw.

2 plavix.tw.

3 "90055-48-4 (clopidogrel).".rn.

4 iscover.tw.

5 pcr 4099.tw. 
6 pcr4099.tw.

$7 \mathrm{sr} 25989 . \mathrm{tw}$.

8 sr 25990c.tw.

9 sr25989.tw.

10 sr25990c.tw.

11 or/1-10

12 Aspirin/

13 aspirin.tw.

14 acetylsalicylic acid.tw.

15 ASA.tw.

16 or/12-15

1711 and 16

18 randomized controlled trial.pt.

19 controlled clinical trial.pt.

20 Randomized controlled trials/

21 random allocation/

22 double blind method/

23 single-blind method/

24 or/18-23

25 exp animal/ not humans/

2624 not 25

27 clinical trial.pt.

28 exp Clinical Trials as Topic/

29 (clin\$ adj25 trial\$).ti,ab.

30 ((singl\$ or doubl\$ or trebl\$ or tripl\$) adj (blind\$ or mask\$)).ti,ab.

31 placebos/

32 placebo\$.ti,ab.

33 random $\$ . t i, a b$.

34 research design/

35 or/27-34

3635 not 25

3726 or 36

3837 and 17

39 ( $2006 \$$ or $2007 \$$ or $2008 \$$ or $2009 \$) . e m$.

4039 and 38

\section{Embase (Ovid)}

1 clopidogrel/

2 clopidogrel.tw.

3 plavix.tw.

4 iscover.tw.

5 pcr 4099.tw.

6 pcr4099.tw.

7 sr 25989.tw.

8 sr 25990 c.tw.

9 sr25989.tw.

10 sr25990c.tw.

11 or/1-10

12 acetylsalicylic acid/

13 aspirin.tw.

14 acetylsalicylic acid.tw.

15 ASA.tw.

16 or $/ 12-15$

1711 and 16

18 controlled clinical trial/

19 random $\$ . t w$.

20 randomized controlled trial/

21 double blind procedure/

22 placebo\$.tw.

23 placebo/

24 factorial\$.ti,ab. 
25 (crossover\$ or cross-over\$).ti,ab.

26 (double\$ adj blind\$).ti,ab.

27 (singl\$ adj blind\$).ti,ab.

28 assign $\$$.ti,ab.

29 allocat\$.ti,ab.

30 volunteer\$.ti,ab.

31 Crossover Procedure/

32 Single Blind Procedure/

33 or/18-32

34 (exp animals/ or nonhuman/) not human/

3533 not 34

3635 and 17

37 ( $2006 \$$ or $2007 \$$ or $2008 \$$ or $2009 \$$ ).em

3836 and 37

\section{Appendix 2. Search strategies 2006}

\section{CENTRAL}

\#1 Clopidogrel

\#2 Plavix

\#3 \#1 or \#2

\section{MEDLINE (Ovid)}

1 clopidogrel.tw.

2 plavix.tw.

3 "90055-48-4 (clopidogrel).".rn.

4 or/1-3

$+\mathrm{RCT}$ filter terms

\section{Embase (Ovid)}

1 clopidogrel.tw.

2 plavix.tw.

3 CLOPIDOGREL/

4 94188-84-8.rn.

5 or/ $1-4$

6 random $\$ . t i, a b$.

7 factorial\$.ti,ab.

8 (crossover\$ or cross over\$ or cross-over\$).ti,ab.

9 placebo\$.ti,ab.

10 (double\$ adj blind\$).ti,ab.

11 (singl\$ adj blind\$).ti,ab.

12 assign $\$$.ti,ab.

13 allocat\$.ti,ab.

14 volunteer\$.ti,ab.

15 Crossover Procedure/

16 Double Blind Procedure/

17 Randomised Controlled Trial/

18 Single Blind Procedure/

19 or/6-18

20 (exp animal/ or exp nonhuman/ or exp animal experiment/) not exp human/

2119 not 20

225 and 21

\section{Appendix 3. Search strategies 2017}

\section{CENTRAL}

\#1 plavix

\#2 clopidogrel

\#3 iscover

\#4 "pcr 4099"

\#5 pcr4099 
\#6 "sr 25989"

\#7 "sr 25990c"

\#8 sr25989

\#9 sr25990c

$\# 10$ (\#1 or \#2 or \#3 or \#4 or \#5 or \#6 or \#7 or \#8 or \#9)

$\# 11 \mathrm{MeSH}$ descriptor: [Aspirin] this term only

$\# 12$ aspirin

\#13 acetylsalicylic

\#14 ASA

$\# 15$ (\#11 or \#12 or \#13 or \#14)

$\# 16$ (\#10 and \#15)

\section{MEDLINE (Ovid)}

1. clopidogrel.tw.

2. plavix.tw.

3. clopidogrel.rn.

4. iscover.tw.

5. pcr 4099.tw.

6. pcr4099.tw.

7. sr 25989.tw.

8. sr 25990c.tw.

9. sr25989.tw.

10. sr25990c.tw.

11. or $/ 1-10$

12. Aspirin/

13. aspirin.tw.

14. acetylsalicylic acid.tw.

15. ASA.tw.

16. or/12-15

17. 11 and 16

18. randomized controlled trial.pt.

19. controlled clinical trial.pt.

20. randomized.ab.

21. placebo.ab.

22. drug therapy.fs.

23. randomly.ab.

24. trial.ab.

25. groups.ab.

26. 18 or 19 or 20 or 21 or 22 or 23 or 24 or 25

27. exp animals/ not humans.sh.

28. 26 not 27

29. 17 and 28

30. $\left(2009092^{\star}\right.$ or $2009093^{\star}$ or $200910^{\star}$ or $200911^{\star}$ or $200912^{\star}$ or $2010^{\star}$ or $2011^{\star}$ or $2012^{\star}$ or $\left.2013^{\star}\right)$.ed.

31.29 and 30

\section{Embase (Ovid)}

1. clopidogrel/

2. clopidogrel.tw.

3. plavix.tw.

4. iscover.tw.

5. pcr 4099.tw.

6. pcr4099.tw.

7. sr 25989.tw.

8. sr 25990c.tw.

9. sr25989.tw.

10. sr25990c.tw.

11. or/1-10

12. acetylsalicylic acid/

13. aspirin.tw.

14. acetylsalicylic acid.tw.

15. ASA.tw. 
16. or/12-15

17. 11 and 16

18. random\$.tw.

19. factorial\$.tw.

20. crossover\$.tw.

21. cross over\$.tw.

22. cross-over $\$$.tw.

23. placebo\$.tw.

24. (doubl\$ adj blind\$).tw.

25. (singl\$ adj blind\$).tw.

26. assign\$.tw.

27. allocat\$.tw.

28. volunteer\$.tw.

29. crossover procedure/

30. double blind procedure/

31. randomized controlled trial/

32. single blind procedure/

33. 18 or 19 or 20 or 21 or 22 or 23 or 24 or 25 or 26 or 27 or 28 or 29 or 30 or 31 or 32

34. exp animals/ or exp invertebrate/ or animal experiment/ or animal model/or animal tissue/ or animal cell/ or nonhuman/

35. human/ or normal human/ or human cell/

36.34 and 35

37.34 not 36

38. 33 not 37

39. 17 and 38

40. ("200938" or "200939" or $20094^{\star}$ or $20095^{\star}$ or $2010^{\star}$ or $2011^{\star}$ or $2012^{\star}$ or $\left.2013^{\star}\right)$.em.

41.39 and 40

42. limit 41 to embase

43. acetylsalicylic acid plus clopidogrel/

44. 17 or 43

45. 38 and 44

46. 45 not 39

47.42 or 46

\section{Appendix 4. Detailed description of included studies}

In the Clopidogrel for High Atherothrombotic Risk and Ischemic Stabilization, Management, and Avoidance (CHARISMA) study, 15,603 people at high risk for a cardiovascular event were randomised either to clopidogrel $75 \mathrm{mg}$ per daily (participants $=7802$; mean age 64.0 years, range 39.0 to 95.0 years; female sex $29.7 \%$ ) plus low-dose aspirin $75 \mathrm{mg}$ daily to $162 \mathrm{mg}$ daily (participants $=7801$; mean age 64.0 years, range 45.0 to 93.0 years; female sex $29.8 \%$ ) or to placebo plus low-dose aspirin (CHARISMA 2006). People were eligible for the trial if they were aged 45 years or older and had one of the following conditions: multiple atherothrombotic risk factors, documented coronary disease, documented cerebrovascular disease or documented symptomatic peripheral arterial disease. After a median of 28 months of follow-up, a predefined primary efficacy endpoint was composed including: first occurrence of myocardial infarction (MI), stroke (of any cause) or death from cardiovascular causes (including haemorrhage). The principal secondary efficacy endpoint was a composite of first occurrence of the primary endpoint, or hospitalisation for unstable angina, a transient ischaemic attack (TIA) or a revascularization procedure (coronary, cerebral, peripheral). The primary safety endpoint was severe bleeding, according to the Global Utilization of Streptokinase and Tissue Plasminogen Activator for Occluded Coronary Arteries (GUSTO) definition, which includes fatal bleeding and intracranial haemorrhage, or bleeding that caused haemodynamic compromise requiring blood or fluid replacement, inotropic support or surgical intervention (GUSTO 1993).

A pilot study to examine the effects of clopidogrel compared to placebo on markers of inflammation in people with metabolic syndrome who were receiving background therapy, including low-dose aspirin (PROCLAIM) was a multi-centre, double-blind, randomised clinical trial (PROCLAIM 2009). A total of 181 people who had metabolic syndrome, an atherothrombotic vascular event or cardiovascular intervention six or more months earlier, and an high sensitivity C-reactive protein (hsCRP) level between $2 \mathrm{mg} / \mathrm{L}$ and $10 \mathrm{mg} / \mathrm{L}$ at screening, were randomised to receive clopidogrel $75 \mathrm{mg}$ daily plus aspirin $81 \mathrm{mg} /$ day (participants $=89$; mean age $( \pm$ standard deviation (SD)) $55.9 \pm 12$ years; range 18.3 to 82.4 years; male sex $43.8 \%$ ) or placebo plus aspirin $81 \mathrm{mg}$ daily (participants $=92$; mean age $( \pm$ SD) $56.3 \pm 12$ years; range 24.4 to 32.3 years; male sex $41.3 \%$ ) for nine weeks to assess the efficacy of each treatment in suppression of inflammatory markers. Change from baseline in the levels of hsCRP, CD40 ligand, P-selectin and N-terminal pro-brain natriuretic peptide at six weeks was assessed to evaluate each treatment.

The Clopidogrel in Unstable angina to prevent Recurrent Events (CURE) study randomised 12,562 people with a non-ST-segment-elevation acute coronary syndrome to receive either clopidogrel loading dose $300 \mathrm{mg}$ orally, followed by $75 \mathrm{mg}$ daily or placebo plus aspirin recommended dose $75 \mathrm{mg}$ to $325 \mathrm{mg}$ (CURE 2001). After a mean follow-up of nine months, a predefined primary endpoint was composed including: death from cardiovascular causes, non-fatal acute MI or stroke (ischaemic and haemorrhagic). A secondary combined endpoint 
was a composite of the primary endpoint and refractory ischaemia. The safety endpoint of bleeding was defined as life-threatening, severe (requiring two or more units of blood transfusions) or minor.

Vavuranakis and colleagues performed a randomised, single-blind, controlled trial (Vavuranakis 2006). They randomised inpatients aged greater than 21 years with acute coronary syndrome without ST-segment elevation to one of two groups: aspirin $325 \mathrm{mg} / \mathrm{day}$ for one week, followed by aspirin $100 \mathrm{mg} /$ day plus clopidogrel $300 \mathrm{mg}$ loading dose followed by $100 \mathrm{mg}$ daily for 36 weeks or aspirin alone $325 \mathrm{mg}$ daily for one week, followed by $75 \mathrm{mg}$ daily for 36 weeks. Levels of serum SCD40L, hsCRP and P-selectin were determined on admission and at eight hours, 48 hours and six days of treatment. By means of clinical follow-up, Kaplan-Meier free-of-major adverse cardiovascular events (MACEs) plots were used to assess the prevalence of MACEs, including cardiovascular-related death, in people with and without high levels of hsCRP (greater than $3 \mathrm{mg} / \mathrm{L}$ ) and soluble CD40 ligand (sCD40L) (greater than $5 \mathrm{\mu g} / \mathrm{L}$ ) for 52 weeks. The study enrolled 86 participants (mean age $( \pm$ SD) $68 \pm 3$ years; 71 men, 15 women).

In the Fast Assessment of Stroke and Transient ischaemic attack to prevent Early Recurrence (FASTER) study, investigators randomly assigned, in a factorial design, 392 people with TIA or minor stroke to clopidogrel $300 \mathrm{mg}$ loading dose then $75 \mathrm{mg}$ daily (198 participants) or placebo (194 participants), and simvastatin $40 \mathrm{mg} /$ day (199 participants) or placebo (193 participants) within 24 hours of symptom onset (FASTER 2007). Baseline characteristics of participants were: clopidogrel only: participants $=98$, mean age $( \pm$ SD) $68.9 \pm 13.0$ years, female sex 46.9\%; simvastatin and clopidogrel: participants $=100$, mean age $( \pm$ SD) $67.1 \pm 12.9$ years, female sex 39\%; double placebo: participants $=95$, mean age $( \pm$ SD) $69.8 \pm 12.3$ years, female sex $55.8 \%$; simvastatin only: participants $=99$, mean age $( \pm$ SD) $66.6 \pm 14.2$ years, female sex $47.5 \%$. All participants were given aspirin and were followed for 90 days. The trial was stopped early due to failure to recruit participants at the prespecified minimum enrolment rate. Descriptive analyses were done by intention to treat. The primary outcome was total stroke (ischaemic and haemorrhagic) within 90 days. Safety outcomes included haemorrhage related to clopidogrel and myositis related to simvastatin.

The Secondary Prevention of Small Subcortical Strokes (SPS3) trial tested two randomised interventions in a $2 \times 2$ factorial design in people with recent symptomatic, magnetic resonance imaging (MRI)-confirmed lacunar stroke: clopidogrel and aspirin versus aspirin alone and two target levels of systolic blood pressure (SPS3 2012). The antiplatelet component of the trial was terminated at the recommendation of the data and safety monitoring committee because of lack of efficacy combined with evidence of harm. It was a double-blind, multi-centre trial involving 3020 participants with recent symptomatic lacunar infarcts identified by MRI. Participants were randomly assigned to receive clopidogrel $75 \mathrm{mg}$ (participants $=1517$; mean age 63 years; male sex 62\%) or placebo daily (participants = 1503; mean age 63 years; male sex 64\%); participants in both groups received aspirin $325 \mathrm{mg}$ daily, and to one of the two groups defined by target levels for systolic blood pressure (less than $130 \mathrm{mmHg}$ versus $130 \mathrm{mmHg}$ to $149 \mathrm{mmHg}$ ) (with participants and practitioners aware of the group assignments). The primary outcome was any recurrent stroke, including ischaemic stroke and intracranial haemorrhage.

The Clopidogrel After Surgery for Coronary Artery DiseasE (CASCADE) study was undertaken to evaluate whether the addition of clopidogrel to aspirin inhibits saphenous vein graft (SVG) disease after coronary artery bypass grafting (CABG) as assessed at one year by intravascular ultrasound (CASCADE 2010). In this double-blind phase II trial, 113 participants undergoing CABG with SVGs were randomised to receive aspirin $162 \mathrm{mg}$ plus clopidogrel $75 \mathrm{mg}$ daily (participants = 56; mean age ( \pm SD) $64.9 \pm 7.5$ years; male sex $91.1 \%$ ) or aspirin $162 \mathrm{mg}$ plus placebo daily (participants $=57$; mean age $( \pm$ SD) $68.1 \pm 7.4$ years; male sex $87.7 \%$ ) for one year. The primary outcome was SVG intimal hyperplasia (mean intimal area) as determined by intravascular ultrasound at one year. Secondary outcomes were graft patency, MACE events and major bleeding.

The Prevention of Coronary arteRY bypaSS occlusion After off-pump procedures (CRYSSA) study was a single-centre prospective randomised controlled study (CRYSSA 2012). The study randomised 300 participants who underwent off-pump CABG to receive aspirin (participants $=150$; mean age $( \pm$ SD) $58.9 \pm 8.3$ years; male sex $75.3 \%)$ or aspirin plus clopidogrel (participants $=150 ;$ mean age $( \pm$ SD) 59.4 \pm 7.7 years; male sex $73.3 \%$ ). Aspirin $100 \mathrm{mg}$ or aspirin $100 \mathrm{mg}$ plus clopidogrel $75 \mathrm{mg}$ daily was initiated when postoperative chest tube drainage was less than $51 \mathrm{~mL} / \mathrm{hr}$ for two hours and participants were followed up for 12 months. Qualitative and quantitative assessment of platelet function, angiographic evaluation of coronary revascularization by 64-slice computed tomography and clinical outcome.

Gao and colleagues performed a single-centre, randomised, controlled trial (Gao 2010). They randomly assigned 249 consecutive participants undergoing elective CABG to two groups: 124 participants received aspirin $100 \mathrm{mg}$ plus clopidogrel $75 \mathrm{mg}$ daily (mean age $( \pm$ SD) $57.9 \pm 8.25$ years, female sex $17.7 \%$ ), and 125 participants received aspirin $100 \mathrm{mg}$ alone daily (mean age $( \pm$ SD) $59.8 \pm 7.92$ years, female sex $16.2 \%)$. Antiplatelet therapies were initiated when postoperative chest tube drainage was less than $31 \mathrm{~mL} / \mathrm{hours}$ for two hours. All participants were invited for clinical follow-up and 64-slice multislice computed tomography angiography analysis at three months postoperatively. Generalized estimating equations analysis was used to determine predictors of graft patency.

The Clopidogrel and Acetylsalicylic acid in bypass Surgery for Peripheral Arterial disease (CASPAR) study randomised 851 participants receiving a unilateral below knee bypass graft (venous or prosthetic) for the treatment of peripheral arterial disease (CASPAR 2010). Participants were enrolled two to four days after surgery and were randomly assigned to clopidogrel $75 \mathrm{mg} / \mathrm{day}$ plus aspirin 75 to $100 \mathrm{mg} /$ day (participants $=425$; mean age $( \pm$ SD) $66.5 \pm 8.7$ years, male sex $75.5 \%)$ or placebo plus aspirin $75 \mathrm{mg} /$ day to $100 \mathrm{mg} / \mathrm{day}$ (participants $=$ 426; mean age ( \pm SD) $65.6 \pm 8.5$ years, male sex $75.8 \%$ ) for six to 24 months. The primary efficacy endpoint was a composite of index-graft occlusion or revascularization, above-ankle amputation of the affected limb or death. The primary safety endpoint was severe bleeding (GUSTO classification) (GUSTO 1993). 
The MIRROR study randomised 80 people undergoing percutaneous angioplasty (PTA) alone or PTA with additional stenting of the femoropopliteal lesion if required (MIRROR 2012). Stents were used if clinically indicated after primary PTA either because of stenosis of greater than $30 \%$ after primary PTA or because of flow-limiting dissection after primary PTA. Participants received either aspirin 500 mg and clopidogrel $300 \mathrm{mg}$ before intervention followed by a daily dose of aspirin $100 \mathrm{mg}$ and clopidogrel $75 \mathrm{mg}$ for six months (participants $=40$; mean age $( \pm$ SD) $69.8 \pm 8.8$ years, male 19 , female 21 ), or the same doses of aspirin plus placebo instead of clopidogrel (participants $=40$; mean age ( \pm SD) $70.2 \pm 11.4$ years, male 23 , female 17 ). Primary endpoints were concentration of platelet activation markers $\beta$ thromboglobulin and CD40L and the rate of participants resistant to clopidogrel. Secondary endpoint was the assessment of clinical status at six months after the intervention. Data after discontinuation of clopidogrel/placebo were not included in the analysis (MIRROR 2012).

The Aspirin and Plavix Following Coronary Artery Bypass Grafting study randomised 20 people undergoing CABG to compare clopidogrel $75 \mathrm{mg}$ daily plus aspirin $81 \mathrm{mg}$ versus aspirin $81 \mathrm{mg}$ and placebo. The primary outcome was postoperative graft patency at two and 52 weeks determined by less than $50 \%$ bypass graft stenosis by cardiac computed tomography angiography (CCTA). The secondary outcomes were MACE, defined as MI, thrombotic events and angina, and safety endpoints defined as thrombolysis in myocardial infarction (TIMI) major and minor bleeding events (ASAP-CABG 2016).

Gasparovic and colleagues performed a single-centre, randomised, controlled trial (Gasparovic 2014). They randomly assigned 219 aspirinresistant people according to multiple electrode aggregometry to receive clopidogrel $75 \mathrm{mg}$ plus aspirin $300 \mathrm{mg}$ (participants $=112$; mean age $( \pm$ SD) $65 \pm 8$ years; male sex $83 \%)$ or aspirin monotherapy $300 \mathrm{mg}$ (participants $=110$; mean age $( \pm$ SD) $65 \pm 9$ years; male sex $82 \%$ ). Adults scheduled to elective primary CABG on postoperative day four underwent an aggregometry-based assessment of their on-aspirin platelet reactivity. Participants found to be aspirin-resistant were randomised into either control or intervention groups. The primary efficacy endpoint was the incidence of major adverse cardiac and cerebrovascular events (MACCEs) at six months. MACCE was a composite outcome including all-cause mortality, non-fatal MI, cerebrovascular accident and cardiovascular rehospitalization. The secondary outcomes were bleeding events and individual MACCE components. They adhered to the Bleeding Academic Research Consortium definitions in presenting the safety endpoint data (BARC 2011).

The TEG-CABG study was a prospective randomised controlled trial with an open-label design. Participants undergoing CABG procedure were preoperatively identified with a hypercoagulable state by thrombelastography (TEG) (TEG-CABG). People were eligible if they were undergoing an isolated elective or urgent CABG procedure, TEG maximum amplitude was $69 \mathrm{~mm}$ or greater, aged 18 years or above and able to give informed consent. Eligible people were randomised to receive aspirin $75 \mathrm{mg}$ (started within six to 24 hours after surgery) plus clopidogrel with a bolus dose of $300 \mathrm{mg}$ (day two postoperatively) follow by $75 \mathrm{mg}$ (participants $=79$, mean age $( \pm$ SD) $65.2 \pm 10.3$ years, female sex 26) versus aspirin $75 \mathrm{mg}$ alone (participants $=81$, mean age ( \pm SD) $66.6 \pm 8.5$ years, female sex 25 ) for three months. The primary study outcome was graft patency assessed at three months by MSCT. Secondary outcomes were thromboembolic events and death, postprocedural day four coagulability itself as an independent factor of graft occlusion, thromboembolic events or death, platelet inhibition and its relation to graft patency, thromboembolic events and death. All outcomes were evaluated three months after surgery.

Zuo and colleagues performed a prospective, randomised, single-centre study of efficacy of clopidogrel plus aspirin as compared with aspirin alone in people with ischaemic cerebrovascular disease, including acute cerebral infarction or TIA, combined with intracranial and extracranial arteriostenosis (Zuo 2017). The study included 200 eligible participants. Median age was 62 years and 79 (39.5\%) participants were female. Participants were randomly assigned (1:1:1) to receive aspirin $100 \mathrm{mg}$ alone (participants $=68$, median age 62.29 years, range 45 to 80 years, 27 female), or clopidogrel $50 \mathrm{mg}$ plus aspirin $100 \mathrm{mg}$ (participants $=66$, median age 61.58 years, range 45 to 80 years, 28 female), or clopidogrel $75 \mathrm{mg}$ plus aspirin $100 \mathrm{mg}$ (participants $=66$, median age 61.55 years, range 45 to 80 years, 24 female), on day one to day 90 . The main study endpoints were recurrence of ischaemic stroke, death from any causes and death from cardiovascular causes (including haemorrhage) in the first 90 days after cerebral infarction or TIA. Several haemorrhagic events were monitored based on the GUSTO definition. Nasal and gum bleeding were also examined. For our review, we considered only the two groups of participants receiving aspirin $100 \mathrm{mg}$ alone and aspirin $100 \mathrm{mg}$ plus clopidogrel $75 \mathrm{mg}$ because no other study in this review used aspirin plus low-dose clopidogrel $(50 \mathrm{mg})$ as the intervention group.

\section{WHAT'S NEW}

Date Event Description

27 September $2017 \quad$ New citation required but conclusions

New studies were included in this update. New author added. have not changed The overall conclusions remain the same. However, the implications for research section has been updated.

27 September $2017 \quad$ New search has been performed

Searches have been re-run to July 2017.

Studies on the optimal duration of clopidogrel plus aspirin therapy in patients with drug-eluting stents and/or bare metal stents was added as an exclusion criterion. 


\section{HISTORY}

Protocol first published: Issue 1, 2005

Review first published: Issue 3, 2007

\begin{tabular}{lll}
\hline Date & Event & Description \\
\hline 9 August 2010 & $\begin{array}{l}\text { New citation required but conclusions } \\
\text { have not changed }\end{array}$ & New author added. \\
\hline 9 August 2010 & New search has been performed & $\begin{array}{l}\text { Searches have been re-run to September 2009. No new studies } \\
\text { were included in this update. }\end{array}$ \\
\hline 8 September 2008 & Amended & Converted to new review format. \\
\hline 9 March 2007 & $\begin{array}{l}\text { New citation required and conclusions } \\
\text { have changed }\end{array}$ & Substantive amendment \\
\hline
\end{tabular}

\section{CONTRIBUTIONS OFAUTHORS}

AS: guarantor of the review; conception and design of the study; data collection; analysis and interpretation of data, providing a clinical perspective; drafting the review; final approval of the version to be published.

MB: data collection; analysis and interpretation of data; final approval of the version to be published.

AT: analysis and interpretation of data; providing a methodological perspective; final approval of the version to be published.

SM: conception, design and co-ordination of the first version of the study; analysis and interpretation of data, providing a methodological perspective; revising the review critically for important intellectual content; final approval of the version to be published.

MPD: data collection; analysis and interpretation of data, providing a methodological perspective; revising the review critically for important intellectual content; final approval of the version to be published.

\section{DECLARATIONS OF INTEREST}

AS: none

MB: none

AT: none

SM: reports grants and fees paid to her institution from GSK, BMS/Pfizer, Aspen, Daiichi Sankyo, Bayer, Boehringer Ingelheim, Sanofi and Sanquin Blood Supply.

MPD: No relevant conflict of interest to declare for the work under consideration. I only declare that, for some congresses, the travel, accomodation and meeting expenses have been paid by different pharmaceutical companies.

\section{SOURCES OF SUPPORT}

\section{Internal sources}

- University of Insubria, Italy.

\section{External sources}

- No sources of support supplied

\section{DIFFERENCES BETWEEN PROTOCOL AND REVIEW}

Differences between review version 2011 and update. 
- Studies on the optimal duration of clopidogrel plus aspirin therapy in people with DES or bare metal stents (or both) was added as an exclusion criterion on February 2017.

- Revascularization procedures were excluded from the primary outcome to reduce the potential for bias. Many episodes of acute coronary events would have been followed by revascularization, leading to double counting of outcomes.

- After reviewing data available in the selected studies, we decided to assess other secondary outcomes for two subgroups of participants. For people undergoing coronary artery bypass grafting, we collected and evaluated data on the risk of repeating revascularization procedures and the rate of postoperative SVG patency. For people undergoing a revascularization procedure for peripheral arterial disease, we collected and evaluated data on the risk of amputation. All these outcomes (i.e. need to repeat revascularization surgery, postoperative SVG patency and risk of amputation) have a significant impact on quality of life, morbidity and mortality.

- Two review authors are no longer involved (Erica Romualdi, Tymen Keller) and there are three new review authors (MPD, MB and AT).

\section{INDEX TERMS}

\section{Medical Subject Headings (MeSH)}

Aspirin [adverse effects] [*therapeutic use]; Cardiovascular Diseases [mortality] [ ${ }^{*}$ prevention \& control]; Clopidogrel; Drug Therapy, Combination [adverse effects] [methods]; Hemorrhage [chemically induced]; Platelet Aggregation Inhibitors [adverse effects] [*therapeutic use]; Randomized Controlled Trials as Topic; Ticlopidine [adverse effects] [ ${ }^{*}$ analogs \& derivatives] [therapeutic use]

\section{MeSH check words}

Humans 